ARCHIWA, BIBLIOTEKI I MUZEA KOSCIELNE Tom 2, zeszyl $1-2$

O. KORNEL GADACZ OFM Cap.

\author{
INWENTARZ ARCHIWUM \\ PROWINCJI KRAKOWSKIEJ \\ ZAKONU OO. KAPUCYNOW
}

LUBLIN 1961 
Po raz pierwszy w dziejach Prowincji Krakowskiej Zakonu OO. Kapucynów doszło do uporządkowania i spisania zawartości archiwum tej prowincji. Określenie Archiwum Prowincji Krakowskiej użyte na karcie tytułowej oznacza komórkę organizacyjną przy urzędzie prowincjała w Krakowie, powołaną do prowadzenia, naukowego opracowania, udostępniania i konserwacji archiwaliów kapucyńskich $\mathrm{z}$ terenu prowincji krakowskiej.

Archiwum to mieści się $w$ siedzibie o prowincjała $w$ Krakowie i przechowuje: $1^{\theta}$ archiwum samej prowincji krakowskiej czyli registraturę urzędu prowincjalskiego oraz registratury instytucji zakonnych zależnych wprost od prowincjała i obejmujacych swym zakresem działania całą prowincję; $2^{\mathbf{0}}$ archiwa (registratury) klasztorów $z$ obszaru prowincji krạkowskiej.

Zasób archiwum prowincji obejmuje, obok archiwaliów w ścisłym tego słowa znaczeniu, także nieco rękopisów pochodzenia niekancelaryjnego, jednakże pozostających $\mathrm{w}$ związku $\mathrm{z}$ historią prowincji krakowskiej lub w ogóle Kapucynów w Polsce. Podręczniki filozoficzne i teologiczne, zbiory kazań i inne rękopisy o charakterze bibliotecznym wchodzą w zasób archiwum prowincji tylko w ty.ch wyjątkowych wypadkach, gdy należą do spuścizn po nieżyjących zakonnikach.

Objaśnienie zasad, według których uporządkowano i opisano zasób archiwum prowincji krakowskiej znajdzie czytelnik w nocie wstępnej do spisu zawartości Archiwum Prowincji Krakowskiej Zakonu OO. Kapucynów.

Autor zdaje sobie sprawę z braków i niedociągnięć opracowania, które oddaje $w$ ręce czytelników. Złożyło się na to kilka przyczyn. Do najważniejszych należy krótki stosunkowo okres czasu, w jakim wypadło mu uporządkować i opisać zawartość archiwum. Nie bez znaczenia był też opłakany stan, $w$ jakim autor zastał materiał archiwalny. Opracowanie go w krótkim czasie, w sposób pozwalający na zestawienie inwentarza odpowiadającego w pełni dzisiejszym wymogom archiwistyki, nie było możliwe. Na inwentarz taki przyszłoby czekać zbyt długo a tymczasem rosnące zainteresowania historyków i potrzeby życia codziennego wymagają prowizorycznej choćby ewidencji zasobu archiwum. Podpisany jest przekonany, że opracowanie niniejsze nie tylko uczyni zadość 
tej potrzebie, ale także pobudzi następców do opracowania lepszego inwentarza.

Należy również zaznaczyć, że praca ta jest wynikiem kursu dla pracowników archiwów kościelnych zorganizowanego w Lublinie $1956 \mathrm{r}$. przez Biblioteke Uniwersytecką KUL.

Zorganizowanie Archiwum Prowincji Krakowskiej Zakonu OO. Kapucynów, doprowadzenie do porządku jego zasobu, wykonanie niezbędnych zabiegów konserwatorskich i opracowanie niniejszego intventarza mogło dojść do skutku tylko dzięki przychylnemu stanowisku śp. prowincjała o. mgra Ernesta Łanuchy, który z pełnym zrozumieniem doniosłosci sprawy oddał do dyspozycji archiwum potrzebne środki finansowe i z żywym zainteresowaniem patronował całej pracy.

Gorące podziękowanie winien autor mgr Marii Bielińskiej, zastępcy dyrektora Naczelnej Dyrekcji Archiwów Państwowych w Warszawie, która zawsze chętnie spieszyła z radami i pomocą. .

W pierwszym etapie pracy, w czasie gromadzenia i wstępnej segregacji zasobu, korzystał autor z uwag dra Zdzisława Niezgody kustosza Archiwum Państwowego w Krakowie. Cenne uwagi prof, dra Kazimierza Kaczmarczyka zostały zrealizowane zwłaszcza w dziale pt. Spuścizny zakonników. W ostatecznej systematyzacji i opisie zasobu wielkiej pomocy podpisanemu udzielił doc. dr Adam Kamiński, zastepca dyrektora Woj. Archiwum Państwowego w Krakowie, który przejrzał i poprawił rękopis niniejszego opracowania.

Wszystkim wymienionym osobom, które przyczyniły się do zorganizowania i opracowania Archiwum Prowincji Krakowskiej Zakonu OO. Kapucynów, składa autor najserdeczniejsze podziekowanie staropolskim „Bóg zapłać".

\section{SPIS TRESCI}

Bibliografia

Wykaz skrótów

Część 1. Archiwum Prowincji Krakowskiej OO. Kapucynów . 7

Wstęp , , , , . . . . . 7

I. Archiwum prowincji krakowskiej . . . . . 15

II. Archiwum seminariów serafickich . . . . . 23

III. Archiwum nowicjatu . . . . . . . . 24

IV. Archiwum studium filozoficzno-teologicznego . . 25

V. Spuścizny zakonników . . . . . . . . .27

VI. Kolekcje archiwum prowincji kralkowskiej , 54

1. Akta i materiały dotyczące prowincji polskiej . 54

2. Akta i materiały dotyczące prowincji ruskiej . 55 
Część 2. Archiwa poszçzególnych klasztorów kapucyńskich . 55

I. Archiwum klasztoru w Krakowie . . . . 55

II. Archiwum klasztoru we Lwowie . . . . . 74

III. Archiwum klasztoru w Sędziszowie . . . . 77

IV. Archiwum klasztoru w Olesku . . . . . . 84

V. Archiwum klasztoru w Rozwadowie . . . . 91

VI. Archiwum klasztoru w Ostrogu . . . . . 99

VII. Archiwum klasztoru w Kutkorzu . . . . . 100

VIII. Archiwum klasztoru w Krośnie . . . . . 103

IX. Archiwum klasztoru w Zamarstynowie . . . 108

$\mathrm{X}$. Archiwum klasz.loru $\mathrm{w}$ Drohobyczu . . . . 110

\section{B I B L I O G R A F I A}

B a r ą c z Sadok ks.: Kronika Oleska. Towarzysz Duchowieństwa Katolickiego. T. 1. Tarnopol 1864.

Bullarium Ordinis Fr. Min. Capuccinorum. T. 1-9. Roma 1740-1893.

Dzień triumfu cichej pracy. Lwowskie Wiadomości Parafialne. 1930, nr 41.

Fijałek Jan ks.: Zamierzona osada zakonu "kapuciańskiego" w pa-

łacu spiskim na rynku w Krakowie. Kwartalnik Historyczny. R. 10: 1896 s. $313 \mathrm{nn}$.

[Ga d a c z Kornel o.]: Archiwa kapucyńskie w Polsce. Zarys informacyjny. Wiadomości Prowincji Krakowskiej OO. Kapucynów. Nr 16: 1957.

G a d a c z Kornel o.: Umiłowane dzieło o. Hieronima. Wiadomości Prow. Krak. OO. Kap. Nr 17: 1958.

G a d a c z Kornel P.: La résidence des Pères Capucins au Mont St. Michel à Blizne (1760-1788). Collectanea Franciscana. T. 30 s. 303-333. Roma 1960.

[Gorlick i Zeno P.]: Conspectus historicus Provinciae Polonae, Analecta Ordinis Minorum Capuccinorum. Roma 1929 s. 102-105. $125-129$.

[Iwanowski E.] Helen i u z Eustachy: Księga klasztorna xx. kapucynów winnickich. Wspomnienia polskich czasów. Lwów 1894.

[J a n och a Florian o.]: Stuletnia rocznica w Rozwadowie nad Sanem. Kraków 1897.

[J a n o ch a Florian o.]: Podczas budowy kościoła w Rozwadowie. Kraków 1900.

[J a n o cha Florian o.]: Na pamiątkę poświęcenia kościoła i przeniesienia parafii rozwadowskiej z kościoła OO. Kapucynów dnia 15 i 16 lipca 1907. Tarnobrzeg 1907.

Kardaszewi cz St.: Dzieje dawniejsze miasta Ostroga. Warszawa 1913.

Klasztor Kapucynów w Olesku. Tygodnik Katolicki. T. 5. Grodzisk 1864. Konsekracja kościoła w Zamarstynowie. Wiek Nowy. Lwów 1930.

$\mathrm{Nr}$ z dnia 8.X. 
Kotula Kazimierz ks.: Kapucyni w Drohobyczu. Przegląd Podkarpacia. Nr 9: 1934.

Lexicon Capuccinum. Roma 1951.

Lwów zbudował nowy kościół. Lwowski Kurier Poranny. $\mathrm{Nr}$ z dnia 8.X.1930.

[M a je r] Ambroży o.: W dwuwiecze sędziszowskiego klasztoru (17391939). Wiadomości Prow. Krak. OO. Kap. Nr 2: 1939.

Melchior a Pobladura P.: Historia Generalis Ordinis Fratrum Minorum Capuccinorum. Pars 1-3. Roma 1947-1951.

[N owak owski] Wacław ks.: Pamiątka 200-letniej rocznicy przybycia do Krakowa OO. Kapucynów 1695. Kraków 1895.

Obertyński Zdzisław ks.: Początki polskiej prowincji Kapucynów. Warszawa 1936.

Obertyński Zdzisław: Das Werden und Wirken der polnischen Kapuzinerprovinz vor der Teilung des Reiches. 1680-1795. Assisii 1938.

Obertyński Zdzisław ks.: Litewskie plany polskich Kapucynów. Wilno 1939.

[Pi otrowski Wiator ks.]: Żywot o. Franciszka z Pescjum kapucyna, wyjęty z rękopisów śp. X. W. P., kap. prowincji polskiej. Alleluja. Warszawa 1843 s. $79-98$.

[S a rna Wł.] Ks. Wł. S.: Kościół i klasztor OO. Kapucynów w Krośnie. Kraków 1891.

Wiadomości z Prowincji Krakowskiej OO. Kap. Nr 18: 1958 (w całości poświęcony o. Honoratowi Jedlińskiemu).

[W o jn a r Alojzy o.]: Rocznik Zakonu Braci Mniejszych Św. O. N. Franciszka Kapucynów Prowincji Krakowskiej św. Józefa w Polsce na rok jubileuszowy 1950. Kraków 1950.

[Giżycki Jan Marek] W ołyniak: Znieșione kościoły i klasztory rzymsko-katolickie przez rząd rosyjski w wieku XIX-ym. Nova Polonia Sacra. T. 1: 1928 (Kraków).

Z naszej przeszłości. Ostróg. Wiadomości z Prowincji Krak. OO. Kap. $\mathrm{Nr}$ 1: 1938.

Z uroczystości w Drohobyczu. Wzlot Seraficki. Wrzes., paźdz., list. 1936. (Kraków).

\section{WYKAZ SKRÓTOW}

$\mathrm{AKD}=$ Archiwum klasztoru w Drohobyczu,

AKK $=$ Archiwum klasztoru $w$ Krakowie,

AKKR $=$ Archiwum klasztoru $\mathrm{w}$ Krośnie,

$\mathrm{AKL}=$ Archiwum klasztoru we Lwowie,

$\mathrm{AKO}=$ Archiwum klasztoru $\mathrm{w}$ Olesku,

AKOS = Archiwum klasztoru $\mathrm{w}$ Ostrogu,

$\mathrm{AKR}=$ Archiwum klasztoru $\mathrm{w}$ Rozwadowie,

$\mathrm{AKS}=$ Archiwum klasztoru $\mathrm{w}$ Sędziszowie,

AKUT $=$ Archiwum klasztoru $\mathrm{w}$ Kutkorzu, 
$\mathrm{AKZ}=$ Archiwum klasztoru $\mathrm{w}$ Zamarstynowie,

$\mathrm{AP}=$ Archiwum Prowincji Krakowskiej,

$\mathrm{APP}=$ Kolekcja Archiwum Prowincji Polskiej w AP.

$\mathrm{APR}=$ Kolekcja Archiwum Prowincji Ruskiej w AP.

Część pierwsza

\section{ARCHIWUM PROWINCJI KRAKOWSKIEJ ZAKONU OO. KAPUCYNÓW}

\section{W S T E P}

1. Historia prowincji krakowskiej

Po dłuższych staraniach ze strony królów polskich a zwłaszcza Jana III Sobieskiego, zakon OO. Kapucynów stworzył w Polsce nową jednostkę zakonną. W r. 1681 przybyli kapucyni do Warszawy a później do Krakowa. Opiekę nad polskimi placówkami obejmowały kolejno prowincje: bolońska, Toskanii i Marchii. W r. 1738 konwenty polskie przeszły pod opiekę prowincji czeskiej a w rok później otrzymały tytuł kustodii. Za nowych rządów kustodia rozprzestrzeniła się terytorialnie i wzrosła liczbowo, tak że w r. 1754 została podniesiona do godności prowincji polskiej, złożonej z dwóch kustodii — polskiej i ruskiej. Nowa prowincja zachowała częściowo zależność od macierzystej prowincji. Pełnন niezależność otrzymała dopiero w r. 1761. Obejmowała wtedy 20 placówek i liczyła 220 zakonników. Okres prowincji polskiej należy do "złotego okresu" w dziejach polskich Kapucynów.

Dopiero rozbiory zadaly cios świetnie zorganizowanej prowincji, która z konieczności została podzielona na trzy niezależne jednostki organizacyjne a mianowicie prowincję polską, galicyjską i ruską czyłli roksolańską.

Po pierwszym rozbiorze w zaborze austriackim znalazły się konwenty we Lwowie, Sędziszowie, Rozwadowie, Olesku, Mariampolu, Krosnie, Kutkorzu i Bliznem (Góra św. Michała), wraz ze 100 zakonnikami pochodzenia obcego. Konwenty te stworzyły prowincję galicyjską a pierwszym komisarzem prowincjalnym zostal mianowany $w$ r. 1781 o. Aleksander Drabek, gwardian lwowski. Był to dzielny zakonnik, kiory sprawował rządy .w najtrudniejszym okresie „józefinizmu“. Uzależniono wtedy zakon całkowicie od władzy świeckiej. Kontakt urzędowy \% kurią generalną został wzbroniony. Zamknięto nowicjaty i studia domowe. Klasztory we Lwowie, Olesku, Mariampolu i Bliznem skasowano. K.westa zosiała zakazana. Administrację klasztorów w swoich diecezjach 
przejęli ordynariusze, którzy sprawọwali rządy za pośrednictwem komisarzy biskupich, wybranych przez siebie. Zakonnicy każdego klasztoru wybierali przełożonego spośród swego grona. W ten sposób zakon skazano na wymarcie. Zakon jednak szybko przystosował się do nowych warunków. Komisarze biskupi diecezji lwowskiej, przemyskiej i tatnowskiej na kapitule we Lwowie 8 maja 1785 r. wybrali o. Aleksandra prowincjałem prowincji galicyjskiej.

Po trzecim rozbiorze w granicach Galicji Zachodniej pozostały trzy konwenty $w$ Krakowie, Lublinie i Lubartowie. Konwenty te stworzyły w r. 1802 kustodię Galicji Zachodniej. Ale już w r. 1806 mocą dekretu cesarkiego, za zgodą ordynariuszy diecezji galicyjskich, kustodia Galicji Zachodniej wraz z prowincją Galicji Wschodniej połączyły się na kapitule w Sędziszowie w prowincję Galicji. Prowincjałem wybrano o. Tadeusza Krawczyńskiego z Warszawy. Wydano wtedy rozporządzenia reformacyjne, aprobowane przez rząd i władze diecezjalne. Rozporządzenia te zmierzały do przywrócenia w klasztorach jednolitej obserwancji zakonnej.

W związku z zajęciem Galicji Zachodniej przez armię Księstwa Warszawskiego, konwenty tamtejsze, korzystając z pomyślnej sytuacji politycznej, przyłączyły się na kapitule w Sędziszowie dnia 18 czerwca 1810 i. do klasztorów w Księstwie. Prowincjałem zmniejszonej prowincji galicyjskiej został wtedy wybrany o. Damazy Stehlik z Pacerzyc. Prowincja obejmowała konwenty w Sędziszowie, Rozwadowie, Olesku, Krośnie i Kutkorzu. Konwent w Krakowie po wielu perypetiach został przyłączony do prowincji galicyjskiej ostatecznie dopiero w r. 1865.

Zarząd prowincji starał się utrzymać dotychczasowy stan posiadania i przywrócić dawną karność zakonną. Skutki "józefinizmu" trwały jednak jeszcze długo i nie pozwoliły osiągnąć zamierzonych celów. Prawie do r. 1912 prowincja walczyła o przetrwanie. W r. 1912 z powodu małej liczby kapłanów utraciła prawa prowincji i stała się komisariatem Galicji, który w r. 1921 został przemianowany na komisariat krakowski. W odrodzonej Polsce nastąpił rozwój komisariatu pod każdym wżględem. O. Czesław Szuber z Haczowa był tym zasłużonym komisarzem prowincjalnym, który nadał nowy rozmach zastygłemu w galicyjskiej atmosferze komisariatowi. Dzięki jego niezmożonej pracy komisariat otrzymał w r. 1939 pełne prawa prowincji. Wyniki międzywojennej pracy o. Czesława zniszczyła częściowo druga wojna światowa. Po jej zakończeniu alumni prowincji krakowskiej ochotniczo zgłosili się do pracy duszpasterskiej za Ziemiach Odzỵskanych, 
Jeszcze dymiły zgliszcza zburzonych miast, krwawiły otwarte rany wojny, gdy kapucyni obejmowali główne punkty odradzającej się polskości od Gdańska poprzez Gorzów, Piłę, Krzyż, Nową Sól, Wrocław, Bolków, Wołczyn, Bytom i wiele innych. Swoje posłannictwo spełnili dobrze W umacnianiu wiary i polskości stali się najbardziej zasłużonymi pionierami. Jest to najpiękniejsza karta $w$ historii polskich Kapucynów.

2. Historia archiwum prowincji"krakowskiej

Archiwum prowincji polskiej było wzorowo zorganizowane. Porządkowaniem aktów zajmował się szereg wybitnych ojców. Ordynacje prowincjalskie podające metody i przepisy porządkowania, przynoszą chlubę polskim zakonnikom i jeszcze dziś nie straciły swej aktualności.

Zespół archiwum prowincji galicyjskiej a później krakowskiej datuje się dopiero od rozbiorów, kiedy to z konieczności dziejowej powstała nowa jednostka kapucyńska na ziemiach polskich, dysponująca własną kancelarią. Od tej chwili możemý śledzić stopniowe narastanie dokumentów i akt w registraturze kancelarii prowincjalskiej.

Podstawą archiwum stały się dokumenty erekcyjne poszczegóinych klasztorów, znajdujących się w zaborze austriackim. Dokumenty te zostały przekazane urzędowo w związku z separacją konwentów Galicji od prowincji polskiej.

O. Pacyfik z Gaja prowincjał prowincji polskiej wydał rozporządzenie w Starym Konstantynowie dnia 25 maja 1781 r., mocą którego powolał specjalną komisję do rewizji archiwum oraz do wydzielenia dokumentów dotyczących konwentów w Galicji. Komisja w składzie o. Stanisława z Markuszowy definitora i gwardiana warszawskiego, o. Serwacego z Hradec Kralové definitora i kustosza rzymskiego i o. Łukasza z Ujścia eksprowincjała i archiwariusza sporządziła wykaz 81 dokumentów należących do siedmiu klasztorów w Galicji. Komisja stwierdziła $\mathrm{w}$ protokole, że dokumenty hospicjum $\mathrm{w}$ Bliznem nie znajdują się w zasobie archiwum prowincji polskiej. Spis dokumentów i. aktów został podpisany przez prowincjała o. Pacyfika i czterech definitorów w. Warszawie dnia 27 sierpnia 1781 r. Wszystkie te dokumenty zostały przekazane prowincji galicyjskiej dnia 13 pażdziernika $1781 \mathrm{r}$. w Rozwadowie. Przejęcia dokumentów dokonała komisja w składzie o. Aleksandra komisarza, o. Wita gwardiana rozwadowskiego i o. Innocentego gwardiana krośnieńskiego. Archiwalia te dały początek archiwum prowincji galicyjskiej. 
Drugiego przejęcia dokumentów dokonał o. Tadeusz kustosz Galicji Zachodniej. W dniu 20 sierpnia 1805 r. odebrał on z warszawskiego archiwum dokumenty dotyczące klasztorów w Krakowie, Lublinie i Lubartowie. W r. 1810 dokumenty te wróciły do warszawskiego archiwum prowincji.

O. Tadeusz zabrał też wtedy akta należące do prowincji Galicji, m. i. akta kapituły z r. 1806 i akta kongregacji definitorskich z lat 1806-1809. Oczywiście w całości zabrał archiwum kustodii Galicji Zachodniej (1795-1806).

Dziś po opracowaniu zasobu archiwum prowincji krakowskiej możenıy stwierdzić, że najmniej zachowało się archiwaliów z okresu początkowego nowej prowincji, który trwał od r. 1781 do 1813. Na przestrzeni prawie trzydziestu lat ścierały się wpływy "józefinizmu" i narodowościowe walki o władzę między zakonnikami polskimi a obcokrajowcami. Z tych burzliwych czasów pozostały nieliczne dokumenty i akta i to raczej w ramach zespołów poszczególnych klasztorów niż we właściwym archiwum prowincji galicyjskiej. Oryginalne acta capitulorum z tych czasów zaginęły prawie w całości. Pozostałe szczątki nie mogą naświetlić całości ówczesnej sytuacji zakonu w Galicji aż do r. 1806. Zachowane acta capitulorum prowincji galicyjskiej zaczynają się dopiero od r. 1813. Od tego też dopiero czasu możemy mieć pełniejszy obraz rozwoju i życia prowincji galicyjskiej i później krakowskiej.

Archiwum prowincji galicyjskiej narastało w ramach kancelarii i registratury prowincjalskiej. Pierwsza registratura z czasów o. Aleksandra obejmowała akta w układzie chronologicznym z sygnaturą liczbową. Od r. 1810 do mniej więcej 1850 zachował się szczątkowy układ chronologiczny ale już bez sygnatur liczbowych. Dopiero póżniej spotykamy zespół aktów prowincji, powiązany w wiązki i fascykuły z napisami orientacyjnymi. Zespół ten nosi wyraźny charakter układu rzeczowego.

Tradycyjnym zwyczajem prowincjałowie przewozili archiwum do konwentu, który obrali sobie za rezydencję. Oczywiście, przy częstych zmianach prowincjałów i złym stanie dróg, akta umieszczane i przewożone $w$ drewnianej skrzynce niszczały. Zwyczaj wyboru rezydencji trwał $w$ całym zakonie aż do r. 1847, kiedy to na kapitule generalnej uchwalono, ażeby definitorium prowincjalne wybrało centralny klasztor na stałą siedzibę prowincjała, w którym rządca prowincji powinien stale przebywać. Na tej kapitule zarządzono utworzenie archiwum w prowincjalskiej rezydencji do przechowywania akt prowincji. Uchwały te $\mathrm{w}$ odniesieniu do prowincji galicyjskiej pozostały właściwie na papierze. 
Dopiero za rządów o. Czesława Szubera wyznaczono w r. 1921 konwent krakowski na stałą rezydencję dla prowincjała. O. Czesław zorganizował nowocześnie kancelarię prowincjalską. Ale archiwum jako komórka organizacyjna poświęcona wyłącznie przechowywaniu i konserwacji dawniejszych akt nie istniało.

Wprawdzie kongregacja generalna wyraziła w r. 1865 życzenie, ażeby w każdej prowincji wybrano odpowiedniego kapłana, który by redagował „annales" lub gromadził potrzebne do nich materiały. Życzenie kongregacji przekazał całemu zakonowi generał o. Mikołaj a s. Joanne Marignano. Komisarz generalny o., Franciszek a Villafranca, zgodnie z ordynacjami generalnymi z r. 1719, zarządził w r. 1879, ażeby wyznaczony zakonnik spisywał wydarzenia z życia każdej prowincji. Podobne życzenia wyraził generał o. Bernard ab Andermatt w r. 1904 dodając, ażeby $\mathrm{w}$ poszczególnych prowincjach gromadzono dokumenty i materiały do opracowania historii prowincji, którą winno się ogłosić drukiem.

Życzenia generała o. Franciszka a Villafranca zostały spełnione w prowincji galicyjskiej o tyle, że opracowano krótką historię prowincji i poszczególnych klasztorów na 4 kartach, wliczając $w$ to wykaz odpustów nadanych prowincji. Również na apel generała o. Bernarda starano się opracować $\mathbf{w}$ r. 1905 obszerniejsze dzieje poszczególnych klasztorów. Nie wszyscy jednak przełożeni wywiązali się z tego obowiązku i może dlatego nie przesłano całości do Rzymu. A tym bardziej nikt się nie zabrał do gromadzenia archiwaliów. Złożyło się na to wiele przyczyn a w szczególności przeciążenie pracą duszpasterską spowodowane brakiem kapłanów. Brakło przede wszystkim ludzi wykształconych i zamiłowanych w tym kierunku. Dopiero na rozkaz generała o. Melchiora a Benisa komisarz prowincjalny o. Marian Najdecki wyznaczył w r. 1928 o. Zenona Gorlickiego i o. Konstantego Jaronia na współpracowników encyklopedii historycznej całego zakonu. Od r. 1928 do 1936 o. Zenon przesłał do Rzymu obszerne materiały dotyczące przeszłości Kapucynów polskich. Również w spuściźnie swej pozostawił bogate materiały do historii zakonu w Polsce. Zorganizowana praca historyków całego zakonu doprowadziła do wydania w r. 1938 pierwszego tomu Lexicon Franciscanum. Dalsze tomy wydawnictwa nie ukazały się. Dopiero w r. 1951 ukazał się jednotomowy Lexicon Capuccinum, w którym pewną ilość haseł opracowali o. Zenon i o. Konstanty. Prace wymienionych ojców nie wysunęły jednak problemu zorganizowania archiwum prowincji. Może dlatego, że jeszcze w czasie pierwszej wojny światowej komisarz prowincjalny o. Konstanty Jaroń, uchodząc przed wojskami rosyjskimi z Sẹdzi- 
szowa do Krosna, zabrał ze sobą w drewnianej i lichej, skrzynce archiwum prowincji, które następnie kazał zakopać w oranżerii krośnieńskiego klasztoru. Po ośmiu miesiącach wydobyto z ziemi zbutwiałe resztki archiwaliów. Przewieziono je póżniej do Krakowa i umieszczono na strychu prowincjalskim. Skamieniały klocek archiwalny został najpóźniej poddany fachowej konserwacji.

Prawie w całości zachowały się natomiast akta prowincjalne od r. 1915, chociaż w międzyczasie dwie wojny światowe, bezkrytyczne brakowanie akt i pozostawianie przez prowincjałów archiwaliów prowincji w osobistych papierach wyrządziło poważne szkody w. zespole archiwum prowincji krakowskiej.

W obecnej chwili akta zespołu archiwum prowincji galicyjskiej i krakowskiej wynoszą $17 \mathrm{mb}$, akta innych zespołów; które weszły w skład archiwum prowincji krakowskiej -- $8 \mathrm{mb}$., ogółem cały zasób Archiwum Prowincji Krakowskiej OO. Kapucynów liczy $25 \mathrm{mb}$. akt.

3. Opracowanie archiwum

Myśl zorganizowania Archiwum Prowincji Krakowskiej OO. Kapucynów powstała po drugiej wojnie światowej, kiedy to autorzy zakonni po dłuższej przerwie sięgnęli znowu po materiały rękopiśmienne dla opracowania wybranych zagadnień z historii prowincji. : Okazało się wtedy; że taka praca jest wprost niemożliwa. Skąpe i fragmentarycznie zachowane źródła znajdowały się częściowo w kancelarii prowincjalskiej a w większej jeszcze liczbie zalegały półki i zakamarki nieskatalogowanej jeszcze wtedy biblioteki krakowskiej oraz strychy nad zakrystią i klasztorem. Akta prowincjalskie były nadto zmieszane z aktami klasztorów prowincji.

Skupienie pomników przeszlości w jedną zwartą całość stało się nakazem chwili. Jednak do roku 1956 nie było ani potrzebnego klimatu ani środków finansowych. Dopiero wybór nowego prowincjała w r. 1956 zaktualizował problem zorganizowania archiwum prowincji krakowskiej i umożliwił jego realizację.

Pierwszym etapem pracy w tym kierunku było zgromadzenie i skupienie $w$ jednym miejscu rozbitej i rozproszonej registratury prowincjalskiej. Trwało to kilka miesięcy. Z kolei przystąpiono do scentralizowania w siedzibie prowincji archiwów klasztornych. Przeszukano kancelarie, biblioteki, strychy i piwnice wszystkich klasztorów prowincji i zgromadzono w konwencie krakowskim, jako siedzibie prowincjała, wszystkie zachowane akta klasztorów. Równocześnie jeszcze w r. 1956 dokonano prowizorycznej segregacji zgromadzonego zasobu. 


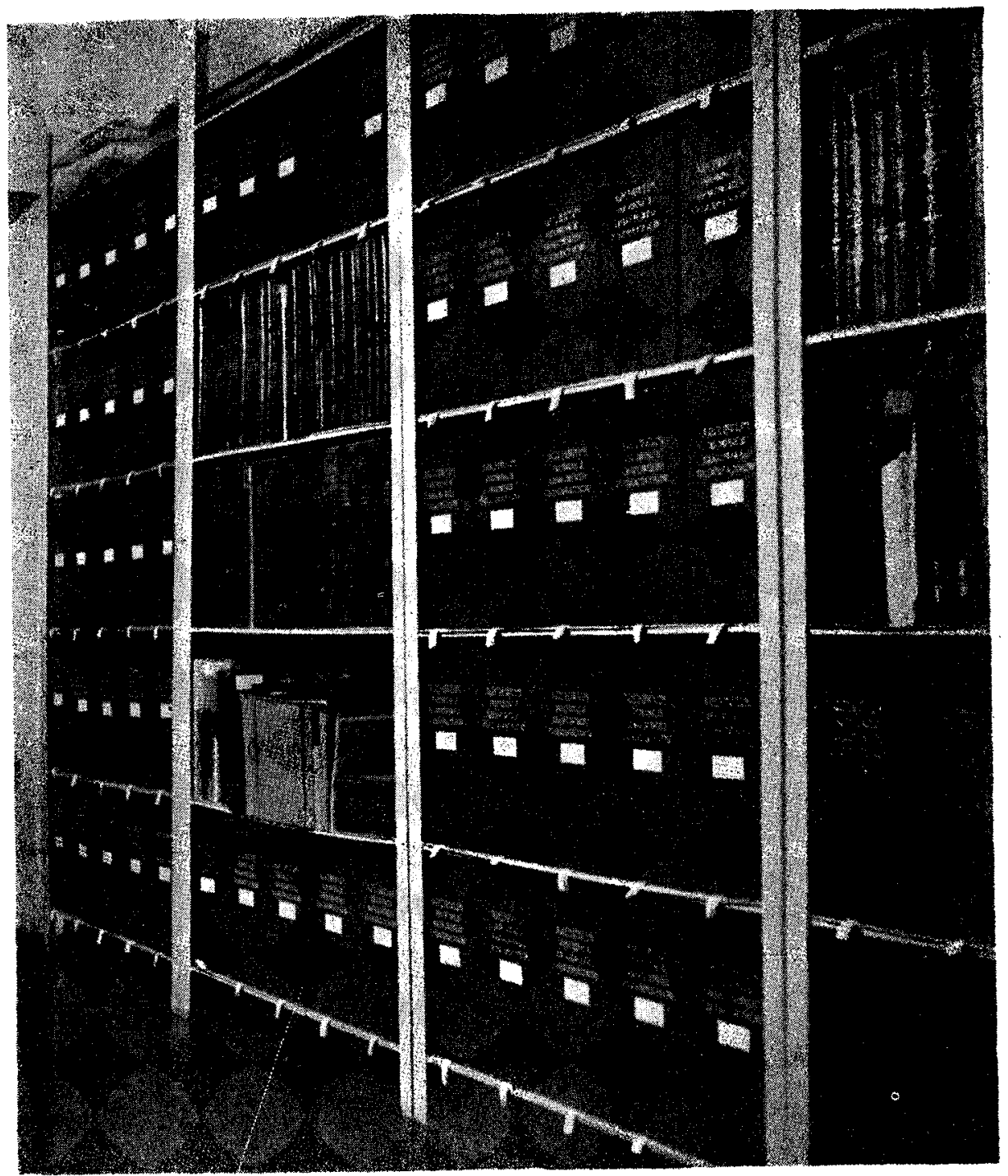

Archiwum Prowincji Krakowskiej Zakonu OO. Kapucynów 
W r. 1957 przystąpiono do opracowania poszczególnych zespołów. Na pierwszym miejscu znalazł się najpełniejszy zespól akt klasztoru oleskiego. Uporządkowano go i ułożono według swoistego schematu. Układ ten pozostawiono $w$ nimiejszym opisie bez zmian, choć jako częściowo chronologiczny a częściowo rzeczowy nie harmonizuje z układem akt innych klasztorów. Jednakże, nowy układ wymagałby zmiany sygnatur a może i rozszycia pewnych jednostek, co odwlekłoby znacznie niniejszą publikację. Za pozostawieniem tu częściowego układu chronologicznego przemawiał argument zachowania w całej prowincji chociaż jednego zespołu akt, który by stanowił przykład układu numerowego tak charakterystycznego dla kancelarii austriackiej.

Natomiast zespoły akt pozostałych klasztorów otrzymały układ rzeczowy. według następującego schematu:

1. Dokumenty fundacyjne.

2. Organizacja i administracja.

3. Działalność religijna.

4. Działalność kulturalna.

5. Sprawy majątkowe.

6. Synopsis exhibitorum. Dzienniki podawcze.

7. Kroniki klasztoru.

8. Rękopisy biblioteczne, mające ścisły związek z dziejami klasztoru.

W obrębie każdego działu ułożono akta i księgi mniej więcej chronologicznie. Ścisłej chronologii nie udało się osiągnąć z powodu różnorodnej treści akt i zachodzenia dat na siebie.

Niektóre rękopisy biblioteczne, jak np. pewne charakterystyczne zbiory kazań oraz spuścizny literackie zmarłych zakonników włączono do zespołu archiwum prowincji. W ten sposób zespoły klasztorne (zgodnie $\mathrm{z}$ ordynacjami kapituł generalnych) zostały odciążone z balastu rękopisow na rzecz właściwego archiwum prowincji.

Zespól archiwum prowincji ksaḳowskiej starano się również ułożyć według podanego schematu, uzupełnionego grupą akt odnoszacych się do stosunków poszczególnych klasztorów z urzędem prowincjalskim (por. jednostki archiwalne oznaczone sygn. AP 18 - AP 28). Zmieścić się w, nim musiały także akta personalne całej prowincji oraz druki urzędowe. Mapa prowincji polskiej i tłoki pieczętne przekazane będą muzeum prowincji.

W drugiej części zespołu archiwum prowincji krakowskiej umiesz:czono akta inștytucji zakonnych zależnych wprost od prowincjała, jak seminarium serafickiego (dziș Niższego Seminarium Duchownego OO. Ka- 


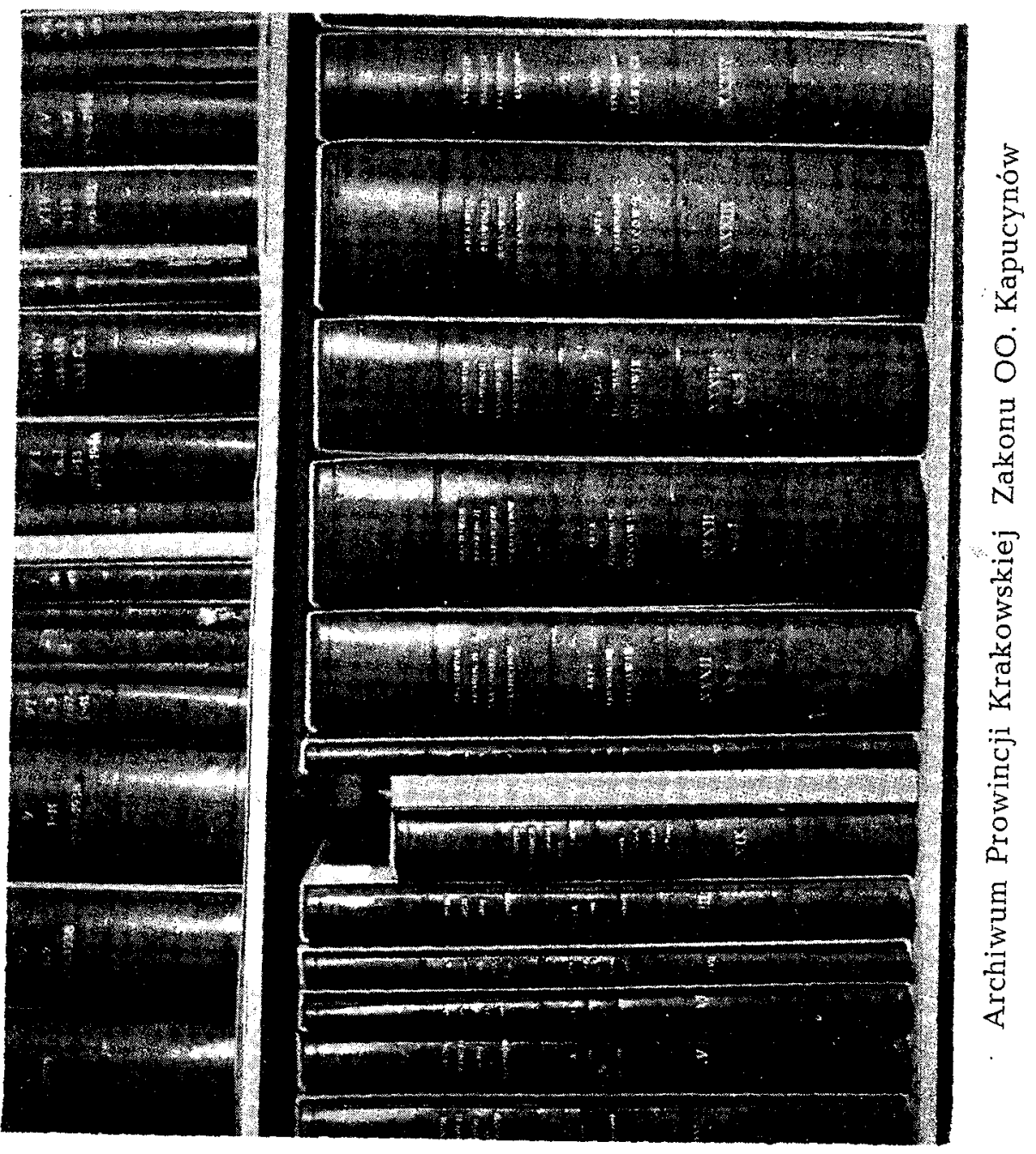


pucynów), nowicjatu, Studium Filozoficzno-Teologicznego 'OO. Kapucynów (dziś Wyższego Seminarium Duchownego OO. Kapucynów). Na samym końcu dano spuścizny i kolekcje poszczególnych ojców, które mają pewną wartość dla dziejów zakonu, oraz kolekcje samego archiwum prowincji krakowskiej, zawierające akta i materiały do dziejów dawnych prowincji polskiej i ruskiej (roksolańskiej).

Scalone w ten sposób Archiwum Prowincji Krakowskiej OO. Kapucynów zawiera wyłącznie rękopisy. Druki urzędowe o charakterze archiwalnym w opisie poszczególnych jednostek wyraźnie zaznaczono. Od autora pochodzą graniczne daty oraz tytuły i uzupełnienia tytułów wielu jednostek zawierających zarówno właściwe archiwalia jak też rękopisy niekancelaryjnego pochodzenia. Tytuły oryginalne rękopisów ujęto w druku w cudzysłów. Tytuły rękopisów nadane przez katalogującego podano bez cudzysłowu. W nawiasy prostokątne ujęto te części tytułów oryginalnych, które zostały uzupełnione przez katalogującego. Objaśnienia tytułów lub treści podano drobnym drukiem.

Jak widać ze spisu treści i z powyższych wywodów, niniejszy inwentarz Archiwum Prowincji Krakowskiej Zakonu OO. Kapucynów dzieli się na dwie wyraźnie odróżniające się części, mianowicie na opis ogólniejszej natury archiwum prowincji krakowskiej oraz opisy archiwów poszczególnych klasztorów kapucyńskich, przedstawionych tutaj $\mathrm{w}$ porządku chronologicznym powstawania tychże klasztorów.

Do niektórych zespołów włączono akta będące jeszcze w użyciu odpowiednich kancelarii (archiwów bieżących). Oto ich wykaz:

AP 10c, 13a, 31, 31a, 38, 45, 66, 67, 74, 76.

AKK 91, 93, 101.

AKKR 13, 18.

AKS 30, 38 .

\section{Konserwacja archiwum}

Prawie wszystkie akta aż do czasú zajęcia się nimi w r. 1956 przedstawiały stertę zakurzonych, brudnych, poszarpaných i częstokroć spleśniałych papierów. Niektóre rękopisy były również zaatakowạne przez kornika. Natomiast papiery i spuścizny zmarłych ojców zachowały się na ogół dobrze.

W czasie przeglądu całego zasobu archiwum zauważono, że akta oprawione w księgi ocalały, wiele zaś akt lużnych przepadło. Postanowiono więc wszystkie akta lużne oprawić w księgi. W latach 1956-1958 oprawiono 129 woluminów w płótno i półskórek oraz kilkanaście w płót- 
no lub. półpłótno. Kilka wartościowych rękopisów oprawiono w skórę. Nowe więc oprawy otrzymaly następujące pozycje:

AP $1,2,3,4,5,6,10,10 \mathrm{~b}, 11$ t. 1,11 t. $2,12,14,15,16 \mathrm{~b}, 17,18$, $19,20,21,22,23,24,25,26,27,28,29,30,30 a, 32,32 a ; 32 b, 33$; $34,35,36,92$. Razem 37 .

AKK 2, 14, 15, 16, 17, 18, 19, 30, 39, 57, 59, 81, 87, 89, 90, 96, 97. Razem 17. AKR $1,2,3,4,5,6,7,10,11,12,13,14,15,17,18,19,20,21,22$, $23,24,25$. Razem 22 .

AKKR 1, 2, 3, 4, 5, 6, 7, 8, 9, 10, 13, 14, 15, 16. Razem 14.

AKL 3. Razem 1.

AKO $1,2,3,4,5,6,7,8,9,10,11,17.18,22,23,24,25,26$. Razem 18.

AKS 1, 3, 4, 7, 10, 11, 14, 15, 21, 23, 24, 31, 32, 33, 34, 35. Razem 16. AKUT 1, 2, 3, 4. Razem 4.

Po zakończeniu konserwacji i opracowaniu ewidencji całego zasobu wszystkie jednostki archiwalne umieszczono na pólkach metalowych stelaży. Archiwum Prowincji Krakowskiej Zakonu OO. Kapucynów zostaje $w$ ten sposób udostępnione dla pracowników naukowych interesujących się dziejami Kapucynów w Polsce.

\section{ARCHIWUM PROWINGJI KRAKOWSKIEJ ZAKONU OO. KAPUCYNOWW}

AP 1. Akta papieskie. 1749-1950.

1. Encykliki, listy i dekrety papieskie. 1749-1950. K. $1-110$.

2. Kongregacja św. Oficjum. Dokumenty odpustowe. 1914. K. 111.

3. Kongregacja dla Spraw Zakonnych. Dekrety. 1857-1923. K. $112-128$.

4. Kongregacja dla Sakramentów. Instrukcja o codziennej Komunii św. w seminariach i zakonnych ośrodkach. 1938. K. $129-130$. $36.4 \times 23 \mathrm{~cm}$, płsk., klb. 130, knlb. 5 .

AP 2. Akta papieskie. 1746-1948.

1. Brevia i dekrety dotyczące kanonizacji i beatyfikacji. Postulacje w sprawie beatyfikacji. 1746-1948. K. 1-29.

2. Odpusty i przywileje dla Zakonu św. Franciszka. K. 30-35.

3. Odpusty nadane Zakonowi OO. Kapucynów oraz dokumenty stwierdzające autentyczność relikwii. 1732-1859. K. 36-90. 2 dokumenty pergaminowe. $36 \times 26.8 \mathrm{~cm}$, płs., klb. 90 , knlb. 12 . 
AP 3. Rozporządzenia generalskie. Korespondencja generałów zakonu z prowincjałami prowincji galicyjskiej. 1821-1899.

$36.4 \times 23 \mathrm{~cm}$, płsk., klb. 459 , knlb. 2 .

AP $\because$ 4. Rozporządzenia generălskie. Korespondencja prowincjałów z generałami zakonu. Karność i orgánizacja zakonu. 1847-1938.

1. Rozporządzenia generalskie. 1900-1938. K. 1-222.

2. Korespondencja prowincjałów z generałami zakonu. 1849.1938. K. 223-233.

3. Karność zakonna: Zärządzenia reformacyjne dla prowincji galicyjskiej. 1847-1916. K. 234-307.

4. Zakon Kapucynów. 1922-1928. K. 308-317.

5. Kapituly generalne. 1926-1938. K. 318-367.

6. Wizytacje generalne. 1853-1935. K. 368-388.

7. Konstytucje zakonu. 1926-1928. K. 389-391. $36.4 \times 23.5 \mathrm{~cm}$, płsk., klb. 391, knlb. 10 .

AP 5. Rozporządzenia konsystorskie. Korespondencja z konsystorzami. 1782-1939.

1. "Prothoculum ab A.R.P. Ministro Provinciali“. 1825-1875. K. 1-33.

Zawiera korespondencję $\mathrm{z}$ Konsystorzem Lwowskim i Przemyskim. Są to koncepty listów, rozporządzeń i kurrend prowincjalskich wysyłanyeh z kancelarii prowincjalskiej:

2. Korespondencja z Konsystorzem Przemyskim. 1831-1860. K. 34-43.

3. Korespondecja z Urzędem Dzịekańskim w Łękaçh, Krośnie i Głogowie. 1828-1873. K. 44-55.

4. Rozporządzenia Konsystorza Krakowskiego. 1827-1942. K. 56 - 108 .

5: Rozporządzenia Konsystorza . Lwowskiego. 1782-1937. K. $109-353$.

6. Rozporządzenia Konsystorza Przemyskiego. 1816-1942. K. $354-476$.

7. Korespondencja z Konsystorzem Chełmskim. 1844. K. 477 479.

8. Korespondencja z Konsystorzem Tarnówskim. 1863-1938. K. $480-487$.

9. Korespondencja z Konsystorzem Kieleckim. 1921. K. 488.

10. Korespondencja z Konsystorzem Łuckim. 1935-1936. K. $489-490$. 
11. Rozporządzenie kard. Fryderykà z Pragi, wizytatora zakonów. 1855-1857. K. 491-494. $37 \times 25.5 \mathrm{~cm}$, płsk., klb. 494 , knlb. 13 .

AP 6. Rozporządzenia władz świeckich. 1787-1941.

1. Korespondencja z władzami świeckimi. 1787-1941. K. 1-12.

2. Rozporządzenia władz świeckich w różnych sprawach. 1827-1916. K. 13-52.

3. Fundusz religijny. 1815-1906. K. 53-97. $36.2 \times 23.5 \mathrm{~cm}$, płsk., klb. 97 , knlb. 5 .

AP" 7. "Formulae Titulorum et Inscriptionum ad Varia Dicasteria et Officia Regiminis et Consistorialis atque Dioecesana".

Spis tekstów formularzy uźywanych w kancelarii prowincjałów Galicji. $22.4 \times 19 \mathrm{~cm}$, płsk., slb. 52, knlb. 2 .

AP 8. „Summula Juris Canonici Regularis in duas Partes divisa... Per P. Marcellum Capucinum S. Thliae Lectorem compillata. A. D. 1793. Varsaviae... Pro usu et Archivio Pris Custodis Prvalis "Custodiae Galliciae applicatur".

Podręcznik prawa kanonicznego zak. dla potrzeb kustodii Galicji Zachodniej.

18.5 x $12 \mathrm{~cm}$, płsk., slb. 174.

AP 9. „Ustawy do Zachowania w Prowincyi naszey oboiey Gallicyi stosownie do Reguły i Konstitucyi naszych Braci Mnieyszych S. O. Françiszka Kapucynów. Podług Dekretu Reformationis uchwalonego na Kapitule przy połączeniu Klasztorów oboiey Gallicyi w iedne Prowincyą S. S. Woyciecha Biskupa i Jana Nepomucena Męczenników, odprawioney w Szędziszowskim naszym Klạsztorze, za iednomyślnym zezwoleniem Rządu, Dyecezanów i wszystkich Oyców Kapitularnych. Zebrane i ułożone Roku Pańskiego 1807.".

$24: 5 \times 19.5 \mathrm{~cm}$, płsk., klb. 22.

AP 10. "Acta Capitulorum Provinciae Galicianae. Tom I". [1813-1849]. 32.5. x $20.2 \mathrm{~cm}$, płsk., slb. 78 , knlb. 3 .

AP 10a. "Acta Capitulorum et Congregationum. Tom II". [1852-1926]. $34.5 \times 21 \mathrm{~cm}$, płsk., slb. 172, knlb. 2.

AP 10b. "Acta Capitulorum et Congregationum. 1813-1926".

Odpis prywatny tomu I. i II Acta Capitulorum, zebranych razem $\mathrm{w}$ jeden tom.

$29.4 \times 20.5 \mathrm{~cm}$, pł., slb. 180 , knlb. 5 .

AP 10c. "Acta Capitulorum Provinciae Cracoviensis. Tom III". [od 1927].

$33.7 \times 21 \mathrm{~cm}$, ppł., klb. 144.

AP 11. Organizacja prowincji galicyjskiej i krakowskiej. Tom I. 1785-1909. 
1. Ekscerpty dokumentów erekcyjnych klasztorów w Rozwadowie, Krośnie i Kutkorzu. (Odpisy). K. 1-2.

2. Krótka historia prowincji galicyjskiej z r. 1880. K. 3-11.

3. Szczątki acta capitulorum. 1785-1867. K. 12-18.

4. Niezadowolenie zakonników. 1803. K. 19-25.

5. Kustodia Galicji Zachodniej, 1801-1803. K. 26-27.

6. "Sermo brevis ante inhoationem Capituli Sędziszoviae die 20 Junii 1806 a. habita". K. 28-30.

7. Ustawy kapituły sędziszowskiej z r. 1806. K. 31-46. Vide AP 9.

8. Sprawa przyłączenia klasztoru OO. Kapucýnów w Krakowie do prowincji galicyjskiej. 1847-1872. K. 47-50.

9. Wybór dyskretów. 1825-1909. K. 51-133. 36.2 x $23.5 \mathrm{~cm}$, płsk., klb. 133, knlb. 10.

AP 11a. Organizacja prowincji galicyjskiej i krakowskiej. Rozporządzenia i korespondencja prowincjałów. Tom II. 1824-1948.

10. Rozporządzenia prowincjałów prowincji galicyjskiej i krakowskiej. 1834-1947. K. 134-348.

11. Korespondencja prowincjałów galicyjskich $\mathrm{z}$ prowincjałami prowincji polskiej. 1852-1895. K. 349-357.

12. Korespondencja $\mathrm{z}$ prowincją warszawską. Sprawa granic obydwóch prowincji. 1931-1948. K. 358-362.

13. Korespondencja prowincjałów $\mathrm{z}$ różnymi osobami. 18241949. K. $363-464$.

$36.3 \times 23 \mathrm{~cm}$, płsk., klb. 134, knlb. 5 .

AP 12. Seminarium serafickie. Korespondencja w sprawie seminarium serafickiego i jego wychowanków. Rachunki. 1928-1937. $36 \times 23.5 \mathrm{~cm}$, płsk., klb. 18, knlb. 2 .

AP 13. Księga kandydatów do zakonu. Tom I. 1921-1937.

$33.8 \times 20.5 \mathrm{~cm}$, płpł., klb. 77 , zapis 10 .

AP 13a. Księga kandydatów do zakonu. Tom II. Od 1930.

$29.8 \times 23 \mathrm{~cm}$, pł., klb. 127 .

AP 14. Werbunek, wychowanie i kształcenie zakonników. Statystyka prowincji. Filiacja do zakonu. 1820-1955.

1. Podania o przyjęcie do zakonu. 1869-1955. K. 1-29.

2. Wykaz nowicjuszy. 1834-1847. K. 30.

3. Sprawozdania z nowicjatu. 1881. K. 31-34.

4. Statystyka prowincji. Ankieta ks. Pirożyńskiego. 1937. K. 35-37.

5. Wykaz klasztorów i zakonników. 1822-1873. K: 38-58. 
6. Studia kleryków. Zaklady naukowe. Swiadectwa. Tezy. 1873-1949. K, 59-110.

7. Swiadectwa złożonych ślubów. 1863-1908. K. 111-140.

8. Zwolnienia z zachowania ślubów. 1820-1948. K. 141-149.

9. Litterae testimoniales. 1878-1912. K. 150-174.

10. Akta święceń. 1870-1903. K. 175-179.

11. Filiacja do zakonu. K. 180.

12. Dyplomy filiacyjne. 1848-1950. K. 181-185.

13. Zrzeszanie się zakonów. 1936. K. 186. $36.2 \times 23.3 \mathrm{~cm}$, płsk., klb. 183, knlb. 15.

AP 15. Życie duchowne. Działalność misyjna i rekolekcyjna. Trzeci Zakon św. Franciszka. 1796-1949.

1. "Liber Missarum". [1799]. K. 1-23.

2. Władze duchowne otrzymane od innych zakonów. 1796. K. 24.

3. Sposób odmawiania różańca. K, 25-26.

4. Szkaplerz św. Józefa. 1912. K. 27.

5. Statystyka prac duchownych. 1934-1945. K. 28-94.

6. Kapelania w Kulparkowie. 1874-1881. K. 95-100.

7. Rekolekcje i misje św. 1935-1937. K. 101-102.

8. Misja w Estoni. 1931-1945. K. 103-159.

9. Misja wschodnia w Lubieszowie. 1937. K. 160-161.

10. O. Serafin Kaszuba - Równe. 1946-1957. K. 162-173.

11. Związek Misyjny Duchowieństwa. 1949. K. 174-175.

12. Trzeci Zakon św. Franciszka. 1869-1936. K. 176-217. $36.2 \times 23.5 \mathrm{~cm}$, płsk., klb. 217, knlb. 14 .

AP 16. „Księga kasowa Prowincji. Tom I“. [1921-1932]. $41.3 \times 16.7 \mathrm{~cm}$, pł., slb. 171, knlb. 4.

AP 16a. "Ksiega kasowa Prowincji. Tom II". [1933-1938]. $30.4 \times 22.4 \mathrm{~cm}$, płpł., slb. 159, knlb, 1 .

AP 16b. Sprawy majątkowe. 1922-1932.

1. Wykaz majątków klasztornych. 1921-1930. K. 1-46.

2. Drukarnia OO. Kapucynów w Krakowie. 1937. K. 47.

3. Stacyjka telefoniczna. 1925. K. 48.

4. Bank Domu Ludowego pod wezwaniem św. Franciszka. 1932. K. 49. $35.9 \times 21.2 \mathrm{~cm}$, płsk., klb. 49 , knib. 6 .

AP 17. Hiștoria prowincji, Historia innych zakonów. 1913-1945.

1. Historia prowincji. K. 1-16.

2. "Capuccini Itali in Polonia". [1935]. K. 17-21. 
3. Kapucyni w więzieniach. 1942-1945. K. 22-41.

4. Sprawa placówek w U.S.A. 1913, K. 42-44.

5. Placówki nieprzyjęte. 1882-1946. K. 45-67.

6. O. Linus w Polsce. 1937. K. 68-69.

7. SS. Franciszkanki - Kęty. 1934. K. 70-71.

8. SS. Sakramentki - Lwów. 1936. K. 72.

9. "Historia SS. Serafitek". [1900]. K. 73-89.

10. Ulotka o Jezuitach. K. 90-91.

36.4 x $23.6 \mathrm{~cm}$, plsk,, klb. 91, knlb. 12 .

AP 18. Akta klasztoru OO. Kapucynów w Krakowie. Dokumenty. Korespondencja. Inwentarze. 1925-1948.

$36.2 \times 23.2 \mathrm{~cm}$, płsk., klb. 96, knlb. 2.

AP. 19. Akta klasztoru OO. Kapucynów w Sędziszowie. Dokumenty. Korespondencja. Inwentarze. Plany. 1863-1955.

$36.2 \times 23.5 \mathrm{~cm}, \mathrm{pksk}$, klb. 93, klnb. 2.

AP 20. Akta klasztoru OO. Kapucynów w Rozwadowie n/Sanem. Dokumenty. Korespondencja. Inwentarze. 1850-1950.

36.2 x $23.5 \mathrm{~cm}$, płsk., klb. 138, knlb. 2 .

AP 21. Akta klasztoru OO. Kapucynów w Olesku. Dokumenty. Korespondencja. Inwentarze. 1861-1945.

36.2 × $23.5 \mathrm{~cm}$, płsk., klb. 109, knlb, 2.

AP 22. Akta klasztoru OO. Kapucynów w. Krośnie n/Wisłolkiem. Dokumenty. Korespondencja. Inwentarze. Plany. 1789-1950.

$36.2 \times 23.5 \mathrm{~cm}$, płsk., klb. 103, knlb. 2.

AP 23. Akta klasztoru OO. Kapucynów w Kutkorzu. Dokumenty. Korespondencja. Inwentarze. 1849-1948.

$36.2 \times 23.5 \mathrm{~cm}$, płsk., klb. 83, knlb. 2.

AP 24. Akta klasztoru. OO. Kapucynów. w Zamarstynowie. Dokumenty. Korespondencja. Inwentarze. Plany. 1903-1943.

$36.2 \times 23.5 \mathrm{~cm}$, płsk., klb. 199, knlb. 2.

AP 25. Akta klasztoru OO. Kapucynów w Drohobyczu. Dokumenty. Korespondencja. Inwentarze. Plany. 1933-1956.

$36.2 \times 23.5 \mathrm{~cm}, \mathrm{płsk}$, , klb. 93, knlb. 2.

AP 26. Akta klasztoru OO. Kapucynów w Ostrogu. Dokumenty. Korespondencja. Inwentarze. Plany. 1931-1948.

$36.2 \times 23.5 \mathrm{~cm}$, płsk., klb. 35, knlb. 2 .

AP 27. Akta hospicjum OO. Kapucynów w Olszanicy. Dokumenty. Inwentarze. Plany. 1937-1958.

36.2 × $23.5 \mathrm{~cm}$, płsk., klb. 38 , knlb. 2.

AP 28. Akta hospicjum w Korabnikach. Dokumenty. Korespondencja. Rachunki. Plany. 1932-1958.

$36.2 \times 23.5 \mathrm{~cm}$, płsk., klb; $93+31, \mathrm{knlb} .3$. 
AP 29. Historia placówek Zakonu OO. Kapucynów na Ziemiach Odzyskanych: 10-lecie pracy. 1945-1955.

1. Piła. K. 1-16. (Oprac. o. Przemysła'w Knap):

2. Krzyż. K. 17-32. (Oprac. o. Krescenty Dudak).

3: Gorzów. K. 33-52. (Oprac. o. Wojciech Strzemecki).

4. Eubianka. K. 53-58. (Oprac. o. Bolesław Wojtuń).

5. Wałcz. K. 59-65. (Oprac. o. Anastazy Barć).

6. Dobiegniew. K. 66-72: (Oprac. o. Ireneusz Nowak).

7. Gdańsk. K. 73--78. (Oprac. o. Aureliusz Puzio).

8. Nowa Sól. - par. św. Michała. K. 79-86. (Oprac. o. Adam Zychowicz).

9. Kożuchów. K: 87-93. (Oprac. o. Peregryn Malinowski).

10: Mirocin Górny. K. 94-101. (Oprac. o. Wacław Miller).

11. Bytom. K. 102--131. (Oprac. o. Kazimierz Niczyński).

Od k. 102-127 wklejona broszura: Die heilige Kreuzkirche von Dr Paul Keinelt, Beuthen, 1937.

12. Wołczyn. K. 132-139. (Oprac. o. Gerard Rysz).

13. Bolków. K. 140-148. (Oprac. o. Zygmunt Nestorowski).

Początki pracy duszpasterskiej na Ziemiach Odzyskanych opracował o. Przemysław Knap na pierwszych kartach woluminu K. 1-10. Oto tytuły poszczególnych rozdziałów: Ojcowie Kapucyni na Zachodzie. Piła - kolebką Ojców Kapucynów na Zachodzie. O. mgr Jerzy Rumak poraz pierwszy w Pile. Pierwszy kapłan polski w Skwierzynie. Ojcowie Kapucyni w Pile. Poświęcenie kościoła św. Antoniego w Pile i pierwsza komunia sw: w Pile. Dom Staszica. Okolica i otoczenie Piły. Kościoly i cmentarze. Pierwsi Ojcowie Kapucyni w Krzyżu. Ojeowie Kapucyni w Gorzowie. Katedra w Gorzowie.

31 x $21.5 \mathrm{~cm}$, płsk., klb. 148, knlb. 3.

$\mathrm{AP}$ 30. "Descriptio Ordinis a Reverendissimo P. Aegidio a Cortona Totius Ordinis FF. Minorum S. Francisci Capucinorum Ministro Generali indicta. Anno 1882. Provincia Galliciae. Brevis discriptio coenobiorum et hospitiorum. Descriptio seu statistica religiosorum". [Tom I. Stan z r. 1882 doprowadzony do r. 1910].

Krótka historia każdego konwentu lub hospicjum oraz personalia zakonników.

$36.2 \times 27.5 \mathrm{~cm}$, płsk., klb. 16 , zapis, 10 .

AP 30a. „Descriptio personalis seu Tabulae vel Catalogus Provinciae Religiosorum, in duas partes divisus:

1. Patrum Clericorumque juxta Religionis antianitatem.

2. "Fratrum Laicorum juxta eumdem ordinem. Galicia". [T. II. 1845-1936]. $22.8 \times 31,5 \mathrm{~cm}$, płsk., klb. 26, knlb, 1 , 
AP 31. "Descriptio personalis seu Tabulae vel Catalogus Provinciae Religiosorum. Patrum Clericorumque juxta Religionis antianitatem. Tom I". [Od 1862].

$44 \times 33.5 \mathrm{~cm}$, płsk., klb. zapis. 17, pozost. knlb.

AP 31a. „Discriptio personalis seu Tabulae vel Catalogus Provinciae Religiosorum. Fratrum Laicorum juxta Religionis antianitatem. Tom II". [Od 1845].

$44 \times 33.5 \mathrm{~cm}$, płsk., klb. zapis. 7 , pozost. knlb.

AP 32. Akta personalne. Ojcowie. Tom I. Lit. A-F. XIX i XX w. $36.2 \times 24.5 \mathrm{~cm}$, płsk., klb. 295 , knlb. 23.

AP 32a. Akta personalne. Ojcowie. Tom II. Lit. F. -M. XVIII -XX w. $36.2 \times 24.5 \mathrm{~cm}$, płsk., klb. od 296-645, knlb. 23.

AP 32b. Akta personalne. Ojcowie. Tom III. Lit. M-Z. (Na końcu akta Stanisława Myślińskiego 1816--1819). XVIII-XX w. $36.2 \times 24.5 \mathrm{~cm}$, płsk., klb. $646-948$, knIb. 29 .

AP 33. Akta personalne nowsze. Ojcowie: Aleksander, Alfons, Anioł, Bogdan, Chryzostom, Gabriel, Honorat, Innocenty, Jan, Konstanty, Laurenty, Lucjan, Marian, Zeno. XIX-XX w. $36.2 \times 23.2 \mathrm{~cm}$, płsk., klb. 439, knlb. 2 .

AP 34. Akta personalne. Klerycy. Lit. A-Z. XIX-XX w. $36.2 \times 23.5 \mathrm{~cm}$, płsk., klb. 248, knlb. 42.

A.P 35. Akta personalne. Bracia. Lit. A-W. XIX-XX w. $36,2 \times 23.2 \mathrm{~cm}$, płsk., klb. 282, knlb. 52 .

AP 36. Akta personalne. Kandydaci do zakonu. Lit. B-Z. XVIII-XX. 36.2 × $23.5 \mathrm{~cm}$, płsk, klb. 73, knlb. 28.

AP 37. „Liber Ordinationum Provincialium Galiciae Ord. FF. Min. Capuccinorum ab Anno Dni 1912-1959".

Księga rozporządzeń prowincjałów prowincji galicyjskiej i krakowskiej. $34 \times 21 \mathrm{~cm}, \mathrm{pk}$, slb. 294 .

AP 38. Księga rozporządzeń Prowincji Krakowskiej OO: Kapucynów. Od 1959.

$32 \times 21 \mathrm{~cm}$, pl., knlb. 300 .

AP 39. Rejestr przesyłek poleconych wysyłanych i przyjmowanych. $1840-1851$.

Rps bardzo zniszezony.

$23.9 \times 17,2 \mathrm{~cm}$, płsk., slb. 57 .

AP 40. "Prothocollum Gestionis ab incipiendo 9 Martii 1837. Ulteriorem continuationem faciat"... [1837-1847].

$23.5 \times 19 \mathrm{~cm}$, pap., slb. 98.

AP 41. "Prothocollum Gestionis. 1847-1865".

$21 \times 17 \mathrm{~cm}$, płsk., slb. 262.

AP 42. "Prothocollum Gestionis. 1873-1883“.

$21,2 \times 17 \mathrm{~cm}$, płpł.. klb. 95. 
AP . 43. "Protocollum gestionis Officii Provincialatus F. F. Min. Capuccinorum Prov. Galiciae. Ab anno 1913 et fine a. 1912". [19121931].

Opr. zniszezona.

$39.4 \times 25 \mathrm{~cm}$, płpł., klb. 99 .

AP 44. "Dziennik podawCZY. 1931-1956".

$40 \times 25 \mathrm{~cm}$, płpł., slb.

AP 45. "Kronika Prowincji Krakowskiej OO. Kapucynów". [Tom II. Od r. 1921].

$32.8 \times 20 \mathrm{~cm}$, płsk., slb.

AP 46. Wiadomości z Prowincji Krakowskiej OO. Kapucynów w Polsce.

Druki urzędowe. Ukazało się 18 numerów. 1938-1958.

AP 46a. Schematyzmy prowincji galicyjskiej i krakowskiej. 1847-1950. Druki urzędowe.

AP 47. Rubrycele używane $w$ prowincji galicyjskiej i krakowskiej. (Opracowywane przez członków prowincji lub sprowadzane z zagranicy). 1906--1958.

Druki urzędowe.

AP 48. Cztery albumy $\mathrm{z}$ fotografiami zakonników.

AP 49. Albumy fotograficzne klasztorów kapucyńskich w liczbie 11.

AP 50. Albumy różne.

\section{ARCHIWUM SEMINARIÓW SERAFICKICH W KRAKOWIE I ROZWADOWIE}

Kraków $1921-1924$.

Kraków 1947-1948.

Rozwadów 1924-1952.

AP 51. Akta. Korespondencja urzędowa $\mathrm{z}$ władzami szkolnymi. Formularze Seminarium Serafickiego OO. Kapucynów w Rozwadowie $\mathrm{n} /$ Sanem. Swiadectwa zdrowia. Program nauki. Dyplom uznania od Chóru Cecyliańskiego dla Internatu OO. Kapucynów w Krakowie 1923 r. Różne. Dołączono 3 urzędowe druki (broszury):

1. Modlitewnik Seminarium Serafickiego OO. Kapucynów Prowincji Krakowskiej. Kraków 1937. 16 ss. 61.

2. Die Seraphischen Schulen. Rundschreiben des Revmus P. Venantius a Lisle - en - Rigault, Generalminister des Kapuzinerordens. Rom 1920. 8` ss. 42. 
3. Życie w Kolegiach Serafickich OO. Kapucynów. Porządek: domowy. Kraków 1931. 8\% ss. 38.

$34.5 \times 25.5 \mathrm{~cm}$, bez opr., klb. $121+3 \mathrm{w}$. w.

AP 52. Dokumenty i świadeckwa uczniów Seminarium. Serafickiego OO. Kapucynów w Rozwadowie n/Sanem. Ułożone altäbetycznie według nazwisk od lit. A--Z. 1921-1952.

$35 \times 22.5 \mathrm{~cm}$ i mniej, bez opr., klb. 674 .

AP 53. Dzienniki lekcyjne. 1921/22-1938/39.

Zdekompletowane.

$37 \times 26 \mathrm{~cm}$ i mniej, opr. pap., jedn. 47 .

AP 54. Katalogi ocen. 1921/22-1938/39.

34 x $24.8 \mathrm{~cm}$ i mniej, opr. pap., jedn. 60 .

AP 55. Korespondencja w sprawach uczniów Seminarium Serafickiego OO. Kapucynów w. Rozwadowie n/Sanem. Ułożona chronologicznie. 1926-1939.

Niekompletna.

$34 \times 24 \mathrm{~cm}$ i mniej, bez opr., klb. 405 .

AP 56. „Księgi kasowe Seminarium Serafickiego". [1928-1939].

3 księgi, 3 fascykuly oraz 20 książek kasowych z odpisami rachunków.

AP 57. „Protokół czynności i załatwień. Seminarium Serafickie OO. Kapucynów w Rozwadowie n/Sanem". [1930-1937].

33.7 × $20.5 \mathrm{~cm}$, płpł., klb. 98.

AP 58. "Protokół czynności i załatwień. 1937-1952".

$33.5 \times 20.5 \mathrm{~cm}$, płpł., klb. 10:0, zapis. 34 .

AP 59. Album fotograficzny. Seminarium Serafickiego OO. Kapucynów w Krakowie i Rozwadowie. 1921-1939.

Fotografie gmachów, profesorów i uczniów.

AP 60. Filia Seminarium Serafickiego w Krakowie. Prowadził o. Urban. Księga rachunkowa. 1947--1948.

$21 \times 16.7 \mathrm{~cm}$, płpł., klb. 45.

III. ARCHIWUM NOWICJATU W SEDZISZOWIE i KRAKOWIE

Sędziszów : 1810-1958.

Kraków . 1891-1909.

AP 61. „Liber Novitiorum in Conventu Sendziszoviensi ad probationem restauratam inscriptorum die 27 Maii $\mathrm{A}^{0}$. 1810. Novitiatus hic antea existens per Capitulum Provinciale die 18 Maii 1810 Sendziszoviae celebratum restauratus est. 1810 -1821".

Bardzo zniszczony. Pod: tą sama sygmatura znajduje się współczesna kopia rękopisu.

24,3 x $18.8 \mathrm{~cm}$, bez opr., knlb. 10 . 
AP 62. "Liber Novitiorum in Conventu Sędziszoviensi ad probationem restauratam inscriptorum; die 25 9-bris Anno Dni 1822. 1822$1882^{\prime \prime}$.

W rękopisie znajdują się też zapisy profesji symplicznej.

$24 \times 19 \mathrm{~cm}$, płpł., slb. 116.

AP 63. "Cathalogus omnium Novitiorum Clericorum ac Laicorum Ordinis Sti. Francisci Capucinorum Sendziszoviae ab A. 1883-1927 indutorum".

$16.2 \times 20.2 \mathrm{~cm}$, płpł., klb. 120 .

AP 64. "Cathalogus Fratrum Novitiorum Clericorum et Laicorum Capucinorum Cracoviensis Anno 1891 in Julio inhoatus sub Provincialatu A.R.P. Floriani ab Haczów et Guardianatu A.V.P. Bernardi a Prądṇik :Biały". [1.1891-1930].

Zawiera także akta profesji wieczystych od r. 1907-1930.

$25 \times 19.8$ ell, płpł., slb. 92 .

AP 65. "Catalogus novitiorum clericorum ac laicorum Órdinis S. Francisci Capucinorum. Provinciae Cracoviensis ab anno $1927 \mathrm{ad}$ annum 1930 indutorum".

$18.2 \times 23 \mathrm{~cm}$, płpł., klb. 33.

AP 66. "Catalogus novitiorum clericorum ac laicorum Ordinis S. Francisci Capucinorum Provinciae Cracoviensis ab anno 1930 indutorum".

$45.5 \times 36 \mathrm{~cm}$, płsk., slb. 498, zapis 33 .

AP 67. „Liber emissorum votorum simplicium". [Od r. 1931]. $33.9 \times 21 \mathrm{~cm}$, płpł., slb. 400 , zapis. 190.

IV." ARCHIWUM STUDIUM FILOZOFICZNO-TEOLOGICZNEGO W KRAKOWIE

Studium Filozoficzno-Teologiczne OO. 'Kapucynów' w Krakowie 1925 - 1945.

Wyższe Seminarium Duchowne OO. Kapucynów" w Krakowie. Od r. 1945.

AP 68. "Katalog główny i sprawozdania z konferencyj i uchwał nauczycielskich w zakładach dla alumnów OO Kapucynów w Krakowie". [1926/27-1929/30].

$32.5 \times 20 \mathrm{~cm}$, płpł., slb. 369, zapis. 222 .

AP. 69. "Katalog klasyfikacyjny oO. Kapucynów. (Gimnazjum)". [1925/26-1935/36].

$41.2 \times 31 \mathrm{~cm}, \mathrm{płsk} ; \mathrm{klb} .314$. 
AP 70. „Katalog klasyfikacyjny Gimnazjum OO. Kapucynów w Krakowie". [Klasa VII-VIII. 1936/37].

$36 \times 30 \mathrm{~cm}$, pap., klb. 38 .

AP 71. "Katalog klasyfikacyjny Gimnazjum i Liceum OO. Kapucynów w Krakowie". [Klasa VIII i Lic. 1937/38-1938/39]. $36 \times 30 \mathrm{~cm}$, pap., klb. 68 .

AP 72. "Katalog klasyfikacyjny Liceum Ogólnokształcącego OO. Kapucynów w Krakowie". [Klasa I i II Lic. Klasa X i XI. Kurs I, II, III. 1946/47]. $41.5 \times 29.5 \mathrm{~cm}$, płpł., klb. 512, zapis. 136 .

AP 73. "Liber censuum Studii Philosophico-Theologici in Conventu Cracoviensi P. P. Capuccinorum". [Gimnazjum kl. V-VIII. Filozofia i Teologia. 1925/26-1933/34].

34.5 x $24.5 \mathrm{~cm}$, płsk., slb. 384, zapis. 111 .

AP 74. „Liber testimoniorum de censibus in doctrina Philosophiae FFr. Capuccinorum ab anno 1925".

$41.5 \times 30.5 \mathrm{~cm}$, płsk., slb. 474 , zapis. 227.

AP 75. "Dziennik lekcyjny Studium Teologicznego w r. 1933/34". $34.5 \times 22.7 \mathrm{~cm}$, pap., klb. 22 .

AP 76. „Liber testimoniorum de censibus in doctrina Theologiae FFr. Capuccinorum ab anno 1928". $41.5 \times 30.5 \mathrm{~cm}$, płsk., klb. 478 , zapis. 416.

AP 77. „Protocollum examinum”. [Protokoły egzaminów dla otrzymania patentu kaznodziejskiego. 1926-1949].

33.5 x $20.3 \mathrm{~cm}$, plpł., klb. zapis. 5 .

AP 78. Katalog klasyfikacyjny $z$ egzaminów dla otrzymania dyplomu kaznodziejskiego oraz $\mathrm{z}$ egzaminów rocznych (pięcioletnich). $1925-1946$.

$33.5 \times 20.5 \mathrm{~cm}$, pl., slb. 194, zapis. 7.

AP 79. Klisze skryptów teologicznych, liturgicznych oraz matryce z nutami. Jednostek 10. 1937-1940.

$25 \times 18 \mathrm{~cm}$, bez opr., jedn. 10 .

AP 80. Archiwum redakcji Wzlotu Serafickiego wydawanego przez kleryków OO. Kapucynów w Krakowie. Artykuły uporządkowane. 1935-1939.

$34 \times 22 \mathrm{~cm}$, bez opr., klb. 588 .

AP 81. „Wzlot Seraficki". Roczniki 1935-1939.

Wydawca: Klerycy Seminarium OO. Kapucynów w Krakowie. Wydd. powielane.

$24 \times 17.2 \mathrm{em}$, bez opr., 5 roczników. 
AP 82. "Ku Szczytom". (Zmiana nazwy czasopisma). Od 1954 do VI 1956 r. "Wzlot Seraficki“. (Powrót do dawnej nazwy). Od IX 1956 do $1959 \mathrm{r}$.

Wydawany na powielaczu przez alumnów Wyższego Seminarium Duchownego OO. Kapucynów w Krakowie.

$29 \times 21.5 \mathrm{~cm}$, bez opr., 6 roczników.

AP 83. „Dziennik podawczy Wzlotu Serafickiego“. [1936-1938].

$33.5 \times 20.3 \mathrm{~cm}$, płpt., slb. zapis. 25.

\section{SPUSCIZNY ZAKONNIKÓW}

1. Spuścizna o. Stanisława Krzysika (1818-1861)

AP 84. "Rękopisma pozostałe po śp. o. Stanisławie Krzysiku z Jasienicy Gwardianie i Definitorze Klasztoru Sędziszowskiego zmarłego r. p. $1861 \mathrm{Kwietnia} 17^{\prime \prime}$. [1830-1855].

$26.5 \times 20 \mathrm{~cm}$, płsk., slb. 620 .

2. Spuścizna o. Leona Dolínskiego (1833-1890)

AP 85. Złote myśli. 1864-1866.

$18.7 \times 11.7 \mathrm{~cm}$, bez opr., klb. 133 .

AP 86. Kazania niedzielne. 1862-1880.

$20 \times 14.5 \mathrm{~cm}$, bez opr., klb. 616 .

AP 87. Kazania pasyjne. $1865-1873$.

$18.3 \times 13 \mathrm{~cm}$, bez opr., klb. 117.

AP 88. Nauki majowe i. kazania maryjne. 1862-1880.

$19 \times 13 \mathrm{~cm}$, bez opr., klb. 560 .

AP 89. Kazania świąteczne. 1860-1880.

$21.5 \times 14.3 \mathrm{~cm}$, bez opr., klb. 143 .

Ap 90. Kazania przygodne. 1860-1889.

$21 \times 17 \mathrm{~cm}$, bez opr., klb. 107 .

3. Spuścizna o. Wacława Nowakowskiego (18291903)

AP 91. Dokumenty osobiste. Curriculum vitae. Działalność religijnopedagogiczna. Kontakty naukowe. Dyplomy. Powstanie styczniowe -- druki ulotne. Nekrologi różne. Nekrologi i wspomnienia o o. Wacławie 1868-1910.

$37 \times 22.3 \mathrm{~cm}$, bez opr., knlb. 159 .

AP 92. "Katalog Biblioteki o. Wacława Nówakowskiego".

$31.5 \times 23.5 \mathrm{~cm}$, płsk., slb. 675.

AP 93. Notes $\mathrm{z}$ zapiskami osobistymi i notatkami $\mathrm{z}$ dzieł religijnych i historycznych.

$9.3 \times 5.4 \mathrm{~cm}, \mathrm{p}$., klb. 62 . 
A.P 94. Notes z zapiskami z dziel religijnych i historycznych. $13 \times 8.2 \mathrm{~cm}$, bez opr., klb. 83 .

AP 95. Notes z zapiskami historycznymi. $13 \times 8.9 \mathrm{~cm}$, pap., klb. 35 .

AP 96. Notes z zapiskami historycznymi. $16 \times 9.5 \mathrm{~cm}$, pap., 'klb. 40 .

AP 97. Brulion $\mathrm{z}$ notatkami treści religijnej i historycznej. $20.8 \times 16.5 \mathrm{~cm}$, pap. klb. 142.

AP 98. Brulion $z$ notatkami historycznymi. $20 \times 16.4 \mathrm{em}$, pap., klb. 17.

AP 99. Brulion z notatkami historycznymi. $21.5 \times 17.2 \mathrm{~cm}$, bez opr., klb. 34 .

AP 100. Brulion $\mathrm{z}$ fragmentami artykułów treści historycznej. $19.8 \times 16 \mathrm{~cm}$, pap., klb. 26.

AP 101. "Modlitwy podczas Mszy św. ułożone przez X. W. K.". $33.5 \times 21 \mathrm{~cm}$, bez opr., slb. 23.

Rps ogłoszony drukiem w Krakowie 1898.

AP 102. „Wianeczek $z$ kwiatów majowych uwity na cześć i chwałę Przenajśw. Matce Bożej Królowej Korony Polșkiej".

$36 \times 22.5 \mathrm{~cm}$, bez opr, klb. 42 .

Rps ogłoszony drukiem w Krakowie 1883. Zdekompletowany.

AP 103. Kazania, fragmenty kazań i materiały clo kazań.

$37 \times 22 \mathrm{~cm}$, bez opr., ktb. 120 .

Część kazań ogłoszona drukiem w Krakowie w. latach 1890-1902.

AP 104. Brulion z materiałami źródłowymi do biografii Maurycego Beniowskiego. (Załączony list M. B. z r. 1761).

$21.5 \times 17.5 \mathrm{~cm}$, pap., klb. 31, niezapis. k. 11-20.

AP 105. Fragmenty artykułów treści historycznej. Notatki hïstorycziè. $35.5 \times 22 \mathrm{~cm}$, bez opr., klb. 50 .

AP 106. Szkice historyczne.

Zdekompletowane.

$34.5 \times 22.5 \mathrm{~cm}$, bez opr., klb. 79 .

AP 107. „Karol Nowakowski. Wspomnienie póśmiertne przez Edwarda z Sulgostowa".

$35.2 \times 22.2 \mathrm{~cm}$, bez opr., klb. 4 .

AP 108. "Częstochowa w obrazach historycznych".

$35 \times 21 \mathrm{~cm}$, bez opr., klb. 61 .

Rps ogłoszony drukiem w Krakowie 1898.

AP 109. Materiały ogólne do historii cudownych obrazów Matki Bożej w Polsce. Medale i pieczęcie. Medaliki. Koronacje obrazów. Krucyfiksy cudowne w Polsce. Spis obrazów Matki Boskiej diecezjami. Pieśni o cudownych obrazach - 7 druków. Notatki różne. $1860-1902$.

$34 \times 21 \mathrm{~cm}$, bez opr., knlb. 755, 7 druków. 
AP 110. Materiały szczegółowe i noty do historii cudownych obrazów Matki Bożej w Polsce. Zebrał ks. Ignacy Polkowski, uzupełnił o. Wacław -Nowakowski. Lit. B-C.

Zbiór powstał w latach 1860-1902.

$28 \times 19.5 \mathrm{~cm}$, bez opr., knlb 259 , wiele druków.

AP 111. Materiały szczegółowe i noty do historii cudownych obrazów Matki Bożej w Polsce. Lit. D-M. Vide AP 110.

$26 \times 17.5 \mathrm{~cm}$, bez opr., knlb. 552, liczne druki.

AP 112. Materiały szczegółowe i noty do historii cudownych obrazów Matki Bożej w Polsce. Lit. N-Z. Vide AP 110.

$27.5 \times 17.5 \mathrm{~cm}$, bez opr., knlb. 260, liczne druki.

AP 113, "Spis miejscowości z cudownymi obrazami Matki Bożej”.

[Napisany przez ks. I. Polkowskiego, uzupełniony przez o. Wacława Nowakowskiego. 1860-1902].

$25.5 \times 22.3 \mathrm{~cm}$, bez opr., kllb. 87; zapis. 61 .

AP 114. "Spis miejscowości z cudownymi obrazami Matki Boskiej”.

[Opracowany przez ks. I. Polkowskiego, kontynuowany przez

o. Wacława Nowakowskiego. 1860?-1902].

$26.5 \times 17.3 \mathrm{~cm}$, plpł., slb. 162 .

AP 115. "O cudownych obrazach Matki Bożej w Polsce".

[Notatki i częściowe opracowania o. Wacława Nowakowskiego. $1880-1902$ ].

$20.5 \times 17 \mathrm{~cm}$, płpł., slb. 899.

AP 116. „O cudownych obrazach w Polsce Przenajświętszej Matki Bożej. Wiadomości historyczne, bibliograficzne i ikonograficzne. Przez ks. Wacława z Sulgostowa, kapucyna".

$34.5 \times 21 \mathrm{~cm}, \mathrm{p}$., slb. 520 .

Rlips ukazał się drukiem w Krakowie w r. 1902.

AP 117. Album cudownych obrazów Matki Bożej w Polsce. (W granicach przed pierwszym rozbiorem Polski). Zebrany przez o. Wacawa Nowakowskiego. 1860?-1902. Teka I - reprodukcje od lit. A-K.

770 reprodukcji w różnych technikach grafiki użytkowej i artystycznej. $115 \times 46 \mathrm{~cm}$, sk.

AP 118. Album cudownych obrazów Matki Bożej w Polsce. (W granicach przed pierwszym rezbiorem Polski). Zebrany przez o. Wacława Nowakowskiego. 1860?-1902.' Teka II - reprodukcje od lit. L-Z.

622 reprodukcje w różnych technikach grafiki użytkowej i artystycznej. $115 \times 46 \mathrm{~cm}, \mathrm{płsk}$. 
AP 119. Kolekcja obrazów Matki Bożej z krajów europejskich. Zebrana przez ks. I. Polkowskiego i o. Wacława Nowakowskiego i ułożona w kopertach według specjalnego klucza. 1850?-1902. Obejmuje 2.623 reprodukcje o mniejszych wymiarach w różnych technikach grafiki użytkowej i artystycznej. $27 \times 32 \mathrm{~cm}$, koperty.

AP 120. Kolekcja obrazów Matki Bożej z krajów europejskich. Zebrana przez o. Waclawa. $1880-1902$.

Zawiera 41 reprodukcji w różnych technikach grafiki użytkowej i artystycznej.

$48.5 \times 39$ i mniej $\mathrm{cm}$.

AP 121. Kolekcja reprodukcji obrazów Matki Bożej pędzla sławnych mistrzów.

Zawiera 98 reprodukcji.

$24.5 \times 16.5$ i mniej cm, kop. pap.

AP 122. Kolekcja ikon rosyjskich i ruskich. Zebrana przez o. Waclawa. 1880-1902.

Zawiera 191 reprodukcji.

31.5 × 25.5 i mniej $\mathrm{cm}$.

AP 123. Kolekcja ikon rosyjskich. Zebrana przez o. Wacława. 18801902.

Zawiera 17 reprodukcji.

54 x 38.5 i mniej $\mathrm{cm}$.

A.P 124. Kolekcja obrazów Chrystusa i świętych Pańskich. Zebrana przez o. Wacława. $1880-1902$.

Zawiera 196 reprodukcji.

$36 \times 26.5$ i mniej $\mathrm{cm}$.

AP 125. Kolekcja obrazów o różnej treści. Zebrana przez o. Wacława $1880-1902$.

Zawiera 145 fotografii i reprodukcji.

$50 \times 36$ i mniej cm.

AP 126. "Zbiór szczegółowy II-gi. Obrazy cudowne w Polsce". [Karty bibliograficzne obrazów i reprodukcji].

Teka pap., $14 \times 24 \mathrm{~cm}, \mathrm{knlb} .243$.

AP 127. "Zbiór szczegółowy II-gi. Swięci polscy. Lit. A-K". [Karty bibliograficzne obrazów i reprodukcji].

Teka pap., $14.5 \times 23.5 \mathrm{~cm}$, knlb. 121 .

AP 128. "Zbiór szczegółowy Il-gi. Swięci polscy. Lit. L-Z". [Karty bibliograficzne obrazów i reprodukcji].

Teka pap., $14.5 \times 24 \mathrm{~cm}$, knlb. 85 .

AP 129. Karty bibliograficzne.

1. Cudowne obrazy Matki Bożej i świętych polskich. K. 18.

3. Historia Kościoła. K. 41.

6. Historia Polski. K. 63. 
8. Rodziny (genealogie rodzin polskich). K. 57.

9. Miejscowości. K. 108.

$11.7 \times 9.5 \mathrm{~cm}$, w 5 kopertach, knlb. j. w.

AP 130. Karty bibliograficzne różnych dzieł.

$17.8 \times 10.7 \mathrm{~cm}$, bez opr., knlb. 171 .

AP 131. Koncepty listów o. Wacława do różnych osób. Korespondencja rodzinna. 1868-1902. Listów 666.

Filanowicz Aleksandra (4), Henryk? (15), Ignacy (2), Jankowska Maria (10), Nowakowska Franciszka (24), NowakowskaŁążyńska Maria (31), Nowakowska Marta (5), Nowakowska Stanisława (10), Nowakowski Stanisław (6), Nowakowski Wladysław (69), Nowakowski Zygmunt (38), Różycka Aleksandra (11), Sałatko Maria (1), Wasilewska Kunegunda (329), Wasilewski Józef ks. T. J. (49), Zaleska (1). Koncepty listów o. W. b. d. (25).

$24 \times 17 \mathrm{~cm}$, bez opr.

AP 132. Listy zakonnic do o. Wacława. 1876-1902. Listów 462.

Benedyktynki-Staniątki: Cherubina (5), Maria Klaudia (1). - - Felicjanki - Kraków (1), Aniela (4), Alojza (1), Anna (51), Chryzostoma Jadwiga (1), Honorata (1), Hugolina (1), Magdalena (3), Nepomucena (3), Prokopia (2), Teodora (1), Serafina (1). Franciszkanki - Lwów: List ks. Stanisława do Franc. (1), Bronisława (1), Maria od Aniołów (2), Maria od Krzyża (23). Karmelitanki - Kraków, ul. Łobzowska: Jadwiga [Wielhorska] (146), Józefa Teresa (1), Teresa od Jezusa (1), Teresa Małgorzata od N. S. (1), Maria Stanisława od Jezusa (1), Maria Xawera od Jezusa (100). - Karmelitanki - Kraków na Wesołej (1), Agnieszka (1), Antonina od Ducha św. (4), Bernarda (10), Cherubina (1), Eufrozyna (1), Rafaela (2), Gabriela Jadwiga (6), Katarzyna (1), Maria od Narodz. P. J. (2), Teresa od N.S.J. i M. (10). - Karmelitanki - Lwów: Franciszka Teresa (3). - Karmelitanki - Przemyśl (2), Maria Bronisława (1), Augustyna (6), Anna od Jezusa (4). - Klaryski - Stary Sącz: Eleonora (1), Helena [Szczepkowska] (1), Kinga (3), Maria Kazimiera (1), Stanisława (10). - Nazaretanki - Kraków (5). - Urszulanki - Kraków: Ludmiła (1), Stanisława (2). - Wizytki - Kraków: Emilia (1), Maria Salezja (1), Tomaszewska Ludwika (2). $24 \times 17 \mathrm{~cm}$, bez opr.

AP 133. Korespondencja o. Wacława. Listy różnych osób do o. Wacława. Lit. A-K. Listów 600. 
Adler Olimpia 1880 (1), Adrian br. kap. b. d. (2), Albert od Nawiedzenia br, karm. bosy 1897-1898 (3), Aleksander? 1881 (2), Andryszkiewicz Wł. 1895 (1), Antoni Maria br. kap. 1900 (1), Atrembek 1900 (1).

B. Eleonora 1897 (1), B. Roch 1888 (1), Baczakjewicz Anna 1884-1891 (14), Bandurski ks. 1900 (1), Baran Maria 1887 (1), Baranowski A. 1901 (1), Baranowski Antoni bp sejneński 1900 (1), Bardzki Izydor 1893 (1), Bartłomiej o. karm. bosy 1902 (2), Bartynowski b. d. (1), Baudiss Wojciech ks. T. J. b. d. (1), Baudoin de Courtenay 1902 (2), Beaupré Seweryna 1884 (1), Benedykt od Jezusa o. karm. bosy 1900 (1), Berger Wilhelm 1897 (1), Bielska Józefa 1903 (1), Biernacka Maria 1898 (1), Biernacka Zoíia 1898-1902 (5), Biesiadzka Maria 1885 (1), Boguszowa 1886-1890 (8), Bochenek Kunegunda b. d. (1), Bratkowski ks. T. J. 1897 (1), Brensztein Michał 1902 (1), Broniec B. 1891-1889 (2), Brzeziński A. 1891 (1), Brzozowska Zofia 1900 (2), Budnicka Teofila 1897 -1898 (3), Bukowski 1898 (3), Bułhak Józef 1890 (1). C. F. [Genewa] 1887 (1), dotyczy śmierci Kraszewskiego, Cecylia 1887 (1), Chmielowska z Kłopotowskich b. d. (1), Chodorowicz Michał b. d. (1), Chodyński ks. 1900 (1), Chojecka Wanda 1890 (1), Chojecka b. d. (1), Chryścińska Anna 1884 (1), Czacki kardynał 1884 (1), Czarnecka Lodzia Maria 1902 (1), Czartoryski Adam książę 1902 (1), Czeczelowa J. (1), Czeczott Mikołaj ks. kap. 1902 (1), Czerwińska Ewa 1881 (1), Czerwińska Maria 1891-1902 (8), Czytelnia Polska - Lwów 1898 (1), Cyrankiewicz Józefa b. d. (1).

Delmassy Stephanne 1895-1898 (3), Dębicki W. b. d. (1), Dłuska Eleonora 1896 (2), Dobrzycka Anna 1893 (1), Drozd. 1889 (1), Dubiecki C. 1895 (6), Dubiecki Marian 1885-1893 (4), Dziewicki M. H. b. d. (1), Drukarnia "Czasu” 1898 (1). Eliasz Wojciech 1898 (1), Eleftern 1892 (1), Emilcia [Genewa] (3), Estreicherówna Maria 1891-1902 (15).

Faszczewski ks. 1891 (1), Felichowski 1897 (2), Feliński Zygmunt arcybp 1882-1891 (6): listy Fel. nr. 1-4 do o. W., pozostałe do innych osób, Fijałek Jan ks. 1897 (1), Florian z Haczowa o. kap. 1901 (6), Freund M. 1899 (2).

Gawroński Fr. Rawita 1897-1902 (2), Gazeta Lwowska, Lwów 1900 (1), Gebethner i Sp. Kraków 1902 (1), Gieburowski ks. 1902 (1), Giejsztor Stanisław 1893 (1), Giller Agaton 1878-1885 
(9), Gloger Zygmunt 1899 (2), Głażewski J. 1876 (1), Gniewosz J. b. d. (2), Gniewoszowa 1891 (1), Gniewosz Maria 1884 (1), Gnoiński Z. W. 1898 (3), Goląo 1897-1902 (9), Gorayska Helena 1902 (3), Górska Seweryna b. d. (4), Górski Konstanty 18921897 (13), Golębiowska Waleria b. d. (1), Grejberowa W. 1891 (1), Grodzicka Klementyna b. d. (2), Gromadzki M. ks. 18811884 (6), Gronkiewicz J. ks. 1883-1887 (2), Groza Maria 1900 (1), Grychowska Helena b. d. (1), Gruszecka Józefa 1898 (1), Gubrynowicz i Schmidt - Lwów 1902 (1), Günther Maria $1897-1898$ (2).

Halski H. dr 1887 (1), Hallerowa 1902 (1), Harajewicz W. dr 1902 (1), Herasimowicz Wł. 1903 (1), Hirmer Max 1890 (1), Hofmajster J. 1888 (3), Hołyńska Jadwiga 1889-1898 (9), Howald 1873-1883 (2), Hölzel M. b. d. (1), Hulewicz Bronisława 18841896 (7), Huśnik and Häusler 1898 (1), Iwański J. dr 1894 (1), Iwanowska Maria b. d. (1), Iwanowski Eustachy [Heleniusz] 1891-1902 (219), Isepp. M. b. d. (1).

J. M. 1888 (1), Jabłoński Tadeusz 1902 (1), Jan Nepomucen o. karm. bosy 1900-1902 (5), Jan Baptysta o. karm. bosy 1897-1901 (3), Janczak ks. b. d. (1), Janczewska Maria 1888 (1), Janowski Wł, 1888 (1), Janowski 1892-1898 (3), Jarosiński Wincenty ks. karm. 1898 (1), Jaroszyński A. b. d: (1), Jaworska 1891 (1), Jasiński Aleksander 1901 (1), Jaśkiewicz Maria 1890 -1892 (2), Jelska A. 1893 (1), Jelska Helena 1888 (1), Jelske Aleksander 1898-1899 (2), Jordanowa N. 1887-1889 (4), Jundziłło Marceli 1893 (1).

K. 1883 (1) w sprawie sekularyzacji ks. Narkiewicza, Kallenbach Józef 1901-1902 (2), Kalinowska Helena 1902 (1), Kalinowski Jerzy ks. 1899-1902 (5), Karol br. kap. 1896-1897 (4), Karbowiak A. 1902 (1), Kazimierz? 1885 (1), Kazimierz? 1892 (1), Kiedrzyńska St. 1900 (1), Kieres Helena 1887-1889 (4), Kieresowa Alojza, Kirchmayerówna Aniela 1880-1902 (17), Kłębkowska Magdalena b. d. (1), Kłopotowska T. 1898 (1), Kluczycka Monika 1902 (1); Kobylińska Monika 1901 (1), Koneczny F. 1897 -1898 (2), Konieczny Jakub ks. 1891 (1), Konopiński Michał 1893 (1), Konopka Tadeusz 1900 (1), Konstanty o. kap. 1898 (1), Korzeniowski Józef dr 1902 (1), Kopernicki F. 1891 (1), Kopernicki Izydor b. d. (2), Kossak Wojciech b. d. (1), Kowalczyk Piotr b. d. (1), Kowalska Weronika b. d. (1), Kowal- 
ski Władysław 1897 (1), Kozicki Z. Dunin ks. 1902 (1), Kozłowska Aniela b. d. (1), Kozłowska Józefa b. d. (1), Kozłowski Wiktor 1901 (1), Kozłowski Kandyd ks. 1893-1894 (2), Koźmiński A. 1886 (1), Krahelski Jan b. d. (1), Krajewski A. 1903 (1), Kraszewska Sabina Helena b. d. (3), Kraszewski Bogusław 1902 (3), Krescenty o. kap. 1891 (1), Kremer Stanisław 1897 (2), Krieger Albertine 1899 (1), Kreszkowska Jadwiga b. d. (1), Kruszewska Wanda 1883-1884 (2), Kuczyk J. b. d. (1), Kułakowski Feliks o. kameduła 1880 (2), jeden list do ks. Narkiewicza, Kulikowska P. 1895 (2), Kulikowski Oskar b. d. (1), Kwaśnicka J. b.d. (1), Kwaśnicki A. 1900 (4).

$25 \times 16 \mathrm{~cm}$, bez opr.

AP 134. Korespondencja o. Wacława. Listy różnych osób do o. Wacława. Lit. L-Ż. Listów 598.

L. Paulina 1891 (1), Lanckorońska Fr. hr. 1889 (1), Lewocka M. 1883-1887 (2), Lignowska Wacława 1900 (1), Lipińska Helena 1895 (2), Lipiński Karol 1891 (2), Lisowska W. 1878 (1), Lisowski J. 1881 (2), Lohman Michalina 1901 (3), Louis de Nicola 1887 (1), Lubomirski J. T. 1899 (3).

Łążyńska M. 1900 (1), Łepkowska Teresa 1882 (2), Łobezowski Józef ks. 1886, 1891 (2), Łubieński Bernard o. redemptorysta 1891 (1), Łuczycka Stefania 1884 (1), Łukasz br, kap. 18991901 (2).

Machnicka F. 1883 (2), Madeyski 1890 (1), Majchrowicz b. d. (1), Marcoin M. 1891-1892 (3), Marynia? 1887 (1), Markiewicz Waleria 1897 (1), Marek Jan 1895 (1), Mania? 1884 (1), Maryański Aleksandèr ks. 1880-1902 (40), Matejko Dora 1896 (1), Maurisset Louise b. d. (1) wiersz, Maurycy o. karm. bosy 1898 (1), Mende Gabriela 1882 (1), Mianowski J. ks. 1883 (1), Michałowska Józefa 1893 (1), Michnikowski 1898 (1), Mielechowicz J. ks. 1880-1881 (3), Mieroszowska Emilia 1893 (1), Mieroszowski Sobiesław 1892-1895 (3), Mikołaj ks. 1902 (2), Mikulski ks. b. d. (1), Milkom, 1902 (1), Morawski M. ks. 1891 (1), Mostowscy 1896 (2), Mrowiński W. ks. 1898 (1), Mrozowska Jadwiga 1894 (1), Musiałowiczówna Emilia 1886 (1), Müllerowa Z. z Siemieńskich b. d. (2), Myczkowski Zeno 1893 (1), 'Narkiewicz Jan ks. 1876 (2), Neumark Maria b. d. (1), Niemojewski Ludwik b. d. (1), Olszewski Leopold 1898 (1), Opidowicz Ludwik b. d. (1), Ortoł ks. 1902 (1). 
Pacińska Anna b. d. (2), Paleczek K. ks. b. d. (1), Piotrowski Onufry ks. 1887 (1), Pietkiewicz Maria 1887 (1), Pietraszek Teresa 1889 (1), Pietraszkiewicz Elżbieta 1890 (2), Pietraszkiewicz F. b. d. (1), Pietraszkiewicz Fr, ks. 1898 (1), Pisarzewska Stanisława 1900 (1), Podlewska Janina 1887 (1), Poldowska Maria 1889 (1), Polewko Kazimierz 1890-1901 (6), Popowska S. b. d. (1), Potocka A. b. d. (2), Poziomska Józefa 1895 (1) dotyczy biografii o. Prokopa, Prokop o. kap. 1876-1889 (25) nr 19-25 w kopertach zaadresowanych przez o. P., Przeździecki Konstanty 1891 (1), Pydynkowski ks. T. J. 1886 (1).

Rafał o. karm. bosy 1891-1901 (5), Rafiański St. ks. 1'899 (1), Rejowicz Jarosław ks. T. J. 1902 (2), Rewieńska Maria 1898 (2), Rey Mikołaj b. d. (4), Rodziewicz Juliusz ks. 1902 (2), Rogozińska Ewelina b: d. (3), Romer A. b; d. (1), Romuald o. karm. bosy 1894-1902 (5), Różycki Walerian ks. 1891 (1), Rulikowska Wacława 1898 (1), Rulikowska 1892 (2), Rulikowski Erazm 1892 (1), Rulikowski Jerzy Józef 1880-1882 (4), Rulikowski Wacław 1883-1892 (20), Rusiecki Bolesław 1899-1900 (13).

S. b. d. (1), S. b. d. (1), Sadowska Anastazja 1895 (1), Sadowski Edward b. d. (1), Sapecki ks. 1899 (1), Sassulicz Konstanty 1901 (1), Scierzka Modest ks. 1881 (1), Sedlmayer 1887 (1), Serwiński M. ks. 1888 (1), Seweryn[Korzeliński?] 1875-1876 (2), Sędziakowski Wł. ks. 1898 (1), Siedlecka Maria 1900 (1), Siedlecki W. ks. 1898-1902 (4), Siemieńska Ludwika 1888-1889 (8), Siemieński Jan ks. b. d. (4), Siemiradzka Seweryna 1899 (3), Sienkiewiczówna b. d. (1), Smoczyński W. ks. 1902 (2), Sobkowski ks. 1902 (1), Sokołowski Maurycy 1899-1901 (2), Sokołowski Sylwester 1902 (1), Sosnowski Anioł ks. 1883 (2), Sławińska A. 1889-1902 (48), Sławiński W. 1899 (1), Skórczewska Jadwiga, Halina i Wanda 1895 (1), Słotwiński Józef 1881 (1), Stadnicki Bogumil 1892 (1), Stanisław ks. 1885-1899 (9), Starorypińska Anna 1878-1879 (7), Starzeńska Stefania b. d. (1), Stępowski Wł. 1899 (1), Strzałecki A. J. art. mal. 1902 (1), Strzelecka Helena 1893 (1), Swiderska Alina 1891-1898 (3), Swięch Fabian 1898 (1), Szadurska Helena 1886 (1), Szajnowa b. d. (1), Szalay Jan ks. b. d. (1), Szezlecka 1899 (1), Szczepański Karol ks. 1889-1899 (4), Szczepkowska Helena 1897 (1), Sztaudynger Izydor 1888 (1), Szwarce Bronisław 1894-1902 (4), Szujska Jad- 
wiga 1888-1889 (5), Szulakowska Wacława 1898 (1), Syrwid ks. b. d. (1).

Tabeńska Elżbieta 1893-1894 (3), Teofil br. kap, 1902 (1), Teresa b. d. 1889 (1), Teresius fr. karm. bosy 1896 (1) z dopiskiem o: Rafała, Tetmajer Ad. 1892 (1), Tomasz o. kap. 1890: (1), Tomaszewski R. ks. 1883 (3), Turowski Zygmunt b. d. (1), Tyszkiewiczowa Katarzyna. 1897-1900 (7); Tyszkiewicz Tadeusz $1888(1)$.

W. K. b. d. (1), Wagner Maria b. d. (1), Waściszewska W. b. d. (1), Wasiutyński. 1877-1878 (5), Wasilewski T. ks. 1900 (1), - Wenzel Kazimierz b. d. (1), Węcławowicz Ludwika: 1893-1898 (2); Wielhorska C. 1876 (17), Wiehorski Zygmunt 1876-1880 (7), Wilkońska Zofia b. d. (2), Wincenta 1899 (1), Wincenty br. karm. 1900 (1) Wincenty Maria o. dominikanin 1892-1902 (2), Winde Alojzy 1888 (1), Wiśniewska K. 1891 (1), Wodzicka A. b. d. (1), Wojciech ks. T. J. 1879-1880 (3), Wojciechowski A. ks. b. d. (1), Wolańska Lidia 1894 (1), Wolański Adam 1900 (1), Wojnarowiczowa W. 1898 (1), Wybranowski Aleksander 1897 (1), W.y.rwińska Anna b. d. (1).

Zabem. Maria Franciszka b. d. (1), Zagórzańska Maria b. d. (1), Zakład Wychowawczy św. St. Kostki - Kraków 1885 (1), Zaleski. Dionizy 1900 (4), Załęski Stanisław ks. T. J. 1892-1902 (12), Załuski Walenty ks. 1898-1899 (2), Zawistowska Antonina b. d. (1), Zaziemski b. d. (1), Zdziechowski Jerzy 1892-1893 (2), Zembaczyński Jan Wł. 1898-1902 (2), Zembrzycka 1896 (1), Zielińska Maria b. d. (1), Zieliński Józef 1902 (1), Zienkowicz Konstancja 1892 (1), Zyskowska Teresa 1883 (1), Żmigrodzki Romuald 1900-1902 (10), Zurowski Adam 1894 (1). $25 \times 16 \mathrm{~cm}$, bez opr,

AP 135. "Iwanowski E.: Listki wichrem do Krakowa z Ukrainy przyniesione". [Rękopis z korektą o. Wacława].

$35 \times 22 \mathrm{~cm}$, bez opr. knlb. 261.

Ukazał się drukiem w Krakowie 1900, 1901 i 1902.

AP 136. „O cudownych obrazach Matki Boskiej w Król. Polskiem, Litwie i na Rusi, o których w "Pruszczu“ wzmianki nie ma, lub niektóre szczegóły $w$ jego zbiorze nie znajdujące się, zbierane $\mathrm{z}$ różnych pism publicznych, książek itp. oraz i niektóre pieśni nowszego utworu. Rękopis Wincentego Janowskiego (¥1875)". $19.5 \times 15.5 \mathrm{~cm}$, bez opr., slb. 221 . 
AP 137. [Giżycki Marek J.] „Podlasiak P. J. K.: Historia zjawionego cudownego obrazu Matki Boskiej... w Leśny".

Ziachowany od slb. 17-140,34.8 x $21 \mathrm{~cm}$, bez opr.

Rps wyd. drukiem w Krakowie w r. 1899.

AP 138. [Giżycki Marek J.] "Podlasiak P. J. K.: Janów Biskupi czyli podlaski z dawnych i współczesnych źródeł napisał"...

$35.5 \times 21 \mathrm{~cm}$, bez opr., slb. 439 .

Rps ogłoszony drukiem w Krakowie w r. 1898.

AP 139. "Trembecki Anastazy: Zestawienie przedmiotów w dziełach Eustachego Heleniusza".

$35.5 \times 21 \mathrm{~cm}$, bez opr., slb. 24 .

Rps wydany daukiem w Krakowie 1900.

AP. 140. "Początki życia zakonnego". [Podręcznik życia zakonnego używany przez o. Wacława].

Druk 00. Franciszkanów we Lwowie 1769.

$12: 5 \times 8.3 \mathrm{~cm}$, sk., slb. 219 .

A:P 141. Fótografie luźne.

Osobiste - 17 sztuk, uczniowie i uczennice -84 sztuki, przyjaciele i znajomi - 93 sztuki, fotografie historyczne (powstania 1831 i 1863$)-205$ sztuk.

AP 142. Album rodzinny Wielhorskich z r. 1900.

$14 \times 10.5 \mathrm{~cm}$, zawiera 23 fotografie.

4. Spuścizna o. Florian a Jan o chy (1855-1921)

AP: 143. Kazania. 1888-1920.

$23 \times 18.5 \mathrm{~cm}$, bez opr., klb. 275 .

AP 144. Kazania. 1900-1920.

$21 \times 17 \mathrm{~cm}$, pkpłk., klb. 200.

AP 145. Modliwy, kazania, nauki rekolekcyjne i misyjne. 1900-1920. $361 \times 23.7 \mathrm{~cm}$, bez opr., klb. 235 .

AP 146. "Nowe nabożeństwo majowe".

$40 \times 25.5 \mathrm{~cm}$, bez opr., klb. 75 .

AP 147. "Obrazy z życia św. Franciszka".

23 ryciny oryginaine wykonane przez W. E. jako ilustracje do pracy o. Floriana pt. „Święty Franciszek Seraficki w pieśni”.

$\mathrm{Na}$ odwrocie ryein znajduje się tekst słowny opracowany przez

o. Floriana. Rzecz ukazała się drukiem w Krakowie $1901 \mathrm{r}$.

$21 \times 15.8 \mathrm{~cm}$, bez opr., klb. 23 .

AP 148. Materiały do historii Zakonu Kapucyńskiego. „Życiorys błogosławionych kapłanów o. Agatanioła i o. Kasjana” kapucynów w Abisynii misjonarzy" k. 1-3. "Życiorys świątobliwego o. Jana Baptysty Dębińskiego, pierwszego Polaka kapucyna, żył od 1550-1632" k. 4-13. „Kapucyni w Polsce” k. 14-49. "Rok Pański. 1768 (klasztor w Krakowie)” k. 50- 
54. „Tułaczka (historia figury M. B. w krakowskim. kościele OO. Kapucynów)" k. 55-56. "Opis pomnika Piotra Swiderskiego przed krakowskim kościołem Kapucynów“n k. 57-58. "Historia cudownego obrazu Matki Bożej w Kutkorzu" k. 5966. „Materiały 'do historii zakonu” k. 67-88. „Fragmentỳ: Haczów w 1863 roku, Duch mnicha na Łysej górze w Haczowie" k. $89-90$.

$34 \times 22 \mathrm{~cm}$, bez opr., klb. 90 .

AP 149. Utwory poetyckie o. Floriana.

$35 \times 22 \mathrm{~cm}$, bez opr., klb. 31 .

AP 150. Sztuki sceniczne o. Floriana. 1903-1918.

"Jasełka” k. 1-3. „Na krzyżowe drogi“ k. 5-8. "Polska w kajdanach" k. 9-13. "Scena z życia Haczowa" k. 14-29. "Swiętokradztwo, dramat, 1903" k. 30-49. "Nauki do tercjarzy" k. 50-53. "Na Saxy. Po ślubną wyprawę i na lepszą strawę, sztuka w 5 aktach" k. 54-80. „Przedstawienie teatrzykowe i rozmowy dziecinne $\mathrm{w}$ rocznicę założenia ochronki pod opieką świętej Bronisławy na Zwierzyńcu w r. 1906-1907" k. 81-93. "Swięty Leon I Wielki papież i doktor Kościoła, sławny pogromca Attyli króla Hunów i zbawca Włoch w roku 452" k. 94-107. „Wywłaszczenie księżny Poznańskiej w roku 1908 dnia 27 lutego" k. 108-124. "Sztuka sceniczna na jubileusz przełożonej Zgromadzenia Służebniczek N.M.P.N.P. w Dębicy“ k. 125-146. „Krótka historia zgromadzenia” k. 147-150. "Nie płacz mamo, z dnia 7. października 1918. Na proklamacje niepodległej i zjednoczonej Polski, obrazek sceniczny" k. $151-159$.

$34 \times 23.5 \mathrm{~cm}$, bez opr., klb. 159 .

AP 151. „Ilg: Geist des heiligen Franciscus". Tłumaczył o. Florian. $34 \times 21 \mathrm{~cm}$, bez opr., klb. 400 .

AP 152. "Hévret M.: O. Marek z Aviano". Tłum. o. Florian. $34 \times 22 \mathrm{~cm}$, bez opr., dwa egz.; I-klb. 45, II-74.

AP 153. „Bruch mit der Welt“". [Rozważania. Tłum. o. Florian]. $34 \times 22 \mathrm{~cm}$, bez opr., klb. 139 .

5. Spuścizna o. Zenona Gorlickiego (1867-1936)

AP 154. Kazania i nauki ascetyczne. $22 \times 18 \mathrm{~cm}$, beż opr., klb. 257 .

AP 155. Kazania na obchód kościuszkowski. $22.5 \times 17.5 \mathrm{~cm}$, bez opr., klb. 6 . 
AP 156. Wykład reguły zakonu.

$22.5 \times 18 \mathrm{~cm}$, bez opr., klb. 105 .

AP 157. „Instrukcja dla zwyczajnych i nadzwyczajnych spowiedników zakonnic" k. 1-20. "Casus conscientiae" k. 21-44. "Collationes morales" k. 45-61.

$21 \times 17.5 \mathrm{~cm}$, bez opr., klb. 61 .

AP 158. Noty bibliograficzne.

$24 \times 18 \mathrm{~cm}$, bez opr. klb. 216 .

AP 159, „Bibliografia”. [Notatki do historii konwentu Kapucynów w Warszawie. Poszukiwania 1933 r. Wykaz dzieł opracowanych przez kapucynów]. „Index nominum scriptorum Capuccinorum" $[1529-1747]$ k. $61-78$.

$22.5 \times 17 \mathrm{~cm}$, pap., klb. 79 .

AP 160. "Notationes bibliographicae". [Noty bibliograficzne opracowane na podstawie zasobów różnych bibliotek]. „Biblioteka kapucyńska w Krakowie" k. 107-127. „Bibl. kap. w Krośnie“ k. 128-137. „Bibl. kap. w Kutkorzu” k. 138-144. „Bibl. Łopacińskiego i Jezuitów w Lublinie" k. 145-154. "Bibl. Seminarium Duch. w Lublinie" k. 155-163. "Bibl. kap. w Nowym Mieście” k. 164-180. „Bibl. kap. w Olesku” k. 181-188. "Bibl. kap. w Rozwadowie" k. 189-197. "Bibl. kap. w Sędziszowie" k. 197-198. „Bibl. kap. w Sędziszowie” k. 198-211.

$22 \times 17.5 \mathrm{~cm}, 11$ brulionów, klb. 211.

AP 161. Materiały do historii Kapucynów w Polsce. Zebrał o. Zenon Gorlicki.

$22 \times 18 \mathrm{~cm}, 22$ bruliony, klb, 461 .

AP 162. Materiały do historii Kapucynów w Polsce. Częściowe opracowania.

$25 \times 19 \mathrm{~cm}, 18$ brulionów, klb. 470 .

AP 163. "Notatki z historii zakonu kapucynów w Polsce". [Tom I].

$20 \times 16.5 \mathrm{~cm}$, pap., slb. 178 .

AP 164. "Notatki do historii prowincji kapuc. w Polsce". [Tom II]. $19.8 \times 16 \mathrm{~cm}$, pap., slb. 300 .

AP 165. "Notatki do historii prowincji kapucynów w Polsce". [Życiorysy sławnych kapucynów. Materiały do biografii o. Jana Baptysty Dembińskiego. Tom III].

$20 \times 16 \mathrm{~cm}$, pap., slb. 332 .

AP 166. „Notatki. Polacy na Rusi. Kapucyni na Rusi. Miary, wagi dawne". [Tom IV].

$20 \times 16 \mathrm{~cm}$, pap., klb. 140 .

AP 167. „Wyciąg z łac. kroniki klasztoru oo. kapucynów w Lublinie“. $20 \times 16 \mathrm{~cm}$, bez opr., klb. 17 . 
AP 168. „Życiorysy kapucynów".

$24 \times 17 \mathrm{~cm}$, bez opr., klb: 72 .

AP 169. „Wspomnienie wypadków dziejowych epoki 1780-1790 w krajach Habsburgom podległych za panowania cesarza niemieckiego Józefa II na tle polityki kościelnej. (Opracowane na podstawie rkp: Epocha rerum gestarum in ditionibus et regnis domus austriacae subiectis disciplinam Ecclesiae Catholicae concernentium, sedente in cathedra Petri Pio VI, tenente clavum Imperii Romani Josepho II ab anno 1780 ad annum 1790 in Galicia)".

$28.5 \times 23 \mathrm{~cm}$, bez opr., klb. 36 .

AP 170. "Złota księga. Literatura wesoła".

Zapis. ręka o. Zenona do str. 51.

$19.5 \times 16.5 \mathrm{~cm}$, płpł., slb. 102 .

AP 171. Korespondencja o. Zenona. Listy różnych osób do o. Zenona. Listów 51.

List b. d. i autora (1), Arndt A. 1912 (1), Basilius a Bolonia kap. 1928-1932 (9), Benziger and Co. A. G. 1910 (1), Bohdziewicz Piotr 1934 (1), Czesław. o. kap. 1932 (1), Cyryl o. kap. 1932 (1), Daniel o. kap. 1929 (2); Dembiński b. d. (1), Dembiński Bronisław. 1934 (1), Dembiński Józef 1934 (1); Gondulf o. kap. 1930 (1), Dominicus fr. kap. 1907 (1), Fredegandus fr. kap. 19281932 (2), Georgius fr. kap. $1911-1915$ (4), Honorat o. kap. 1910 (1), Katolik - Spółka Wydawnicza w Bytomiu 1930 (1), Kazimierz fr. kap. 1934 (1), Konstanty o. kap. 1928 (4), Krzemieniecki Jan ks. 1926 (1), Kuria Metropolitalna we Lwowie 1928 (1), Leopoldus fr. kap. 1935 (1), Litwiński Leonard 1933 (2), Lewiński Jan ks. 1933 (1), Marian o. kap. b. d.' (1), Mycielska z Dembińskich Maria 1934 (1), Nowakowski Wł. ks. 1934 (2), Steinen P. 1918 (1), Swirtun ks. b. d. (2), Tokarz Wacław 1933-1934 (2), Z.G.J. 1913 (1).

$34 \times 22$ cm, bez opr., klb. 62 .

6. Spuścizna o. Anioła Madejskiego (1873-1951)

AP 172. Dokumenty osobiste $1901-1950 \mathrm{k} .1$-15. Karty wpisowe do bractw kościelnych 1893-1918, sztuk 4. Legitymacje szkolne i inne 1915-1935, sztuk 4. Legitymacja Michaliny Madejewskiej 1915. Książeczka wypłat za naukę religii w szkołach 1908-1918, sztuk 2. Książka wypłat za naukę religii należąca 
do ks. Jerzego Anioła 1910-1911. Kalendarzyk kieszonkowy 1904. 1893-1950.

$34 \times 23.5 \mathrm{~cm}$, dokumentów klb. 15, jedn. arch. 14 .

AP 173. Notes klasyfikacyjny.

$12.8 \times 7.5 \mathrm{~cm}, \mathrm{sk} ., \mathrm{klb} .116$.

AP 174. Dyspozycje i szkice kazań.

$19.8 \times 12.5 \mathrm{~cm}$, płpł., klb. 314 .

AP 175. Dyspozycje i szkice kazań.

$19 \times 13 \mathrm{~cm}$, bez opr., klb. 444 .

AP 176. Materiały do kazań. Kazania. Poezje różnych autorów i o. Anioła.

$22 \times 18 \mathrm{~cm}$, bez opr., klb. 180 .

AP 177. Album z wycińkami z gazet i czasopism o działalności duszpasterskiej, społecznej i patriotycznej o. Anioła od r. 1900-1939. $19.5 \times 12.5 \mathrm{~cm}, \mathrm{pł}$, klb. 100 .

AP 178. Pamiętnik o. Anioła 1873-1912.

Pisany ołówkiem na luźnych kartach.

$21 \times 17 \mathrm{~cm}$, w kopercie, slb. 26.

AP 179. Odpis pamiętnika o. Anioła. K. 1-12. Wiersze: "Mój nagrobek" 1948 k. 13, "Przed moim jubileuszem" 1948 k. 14, oraz 3 wiersze b. t. $1948-1949$ k. 15-17. 1873-1949.

$30 \times 21 \mathrm{~cm}$, bez opr, klb. 17 .

AP 180. Korespondencja o. Anioła 1902-1950. Listy różnych osób do o. Anioła. Listów 88.

Anatol o. 1939 (1), Baziak Eugeniusz ks. 1933 (1), Brojakowa Janina 1949 (1), C. Z. 1907 (1), Czadowska Stefania 1948 (1), Czesław o. kap. prow. 1938 (1), Ernestyna s. serafitka 1950 (1), Haraschin K. K. 1948 (1), Honorat o. kap. 1927 (1), Innocenta s. serafitka 1948 (1), Kaczmarczykowa Maria b. d. (4), Kaliksta s. serafitka 1948 (1), Kalinkowa Maria 1950 (1), Konopka Feliks 1949 (1), Malczewski Rafał 1947 (1), Męciński Mieczysław 1902 (1), Nodzyński Józef ks. b. d. (1), Pruszyńska Zofia 1947 (1), Rajmund br. kap. b. d. (1), Rowiński Stanisław dr 1948 (1), "Sokół" Borysław 1905 (1), "Sokół" Kraków 1904 (2), "Sokól” Lwów 1906-1912 (2), Stowarzyszenie wzajemnej pomocy kupców i młodzieży handlowej 1905 (1), Swięcka Eugenia 1950 (2), Teresa s. b. d. (1), Towarzystwo Młodzieży Polskiej im. Tadeusza Kościuszki Lwów 1912-1914 (3), Towarzystwo Ochotniczej Straży Pożarnej w Łoniowcach, b. d. (1), Towarzystwo Szkoły Ludowej w Złoczowie 1903 (1), Towarzystwo Szkoły 
Ludowej w Zamarstynowie b. d. (1), Tytus o. kap. 1939 (1), Vetulani Elżbieta 1935-1944 (2), Vetulani Tadeusz 1946 (1), Zofia, Janka 1925 (1), Zofia siostra miłosierdzia 1917 (1), Znaniecka Maryla 1926 (1).

$34.5 \times 23.5 \mathrm{~cm}$, bez opr., klb. 98 , list. 45 , poczt. 43 .

AP 181. Kolekcja obrazków religijnych. $25 \times 18.5 \mathrm{~cm}$, obrazków 71.

AP 182. Laurki imieninowe.

$32.5 \times 25 \mathrm{~cm}, 14$ laurek i wierszy imieninowych.

AP 183. Album fotografii rodzinnych.

$13.2 \times 10.7 \mathrm{~cm}$, album bez okładzin, 14 fotografii.

AP 184. Fotografie o. Anioła i inne.

$20.5 \times 13.8 \mathrm{~cm}, 61$ fotografii.

7. Spuścizna o. Marian a Na jdeckiego (1876-1951)

AP 185. Dokumenty osobiste, legitymacje,' świadectwa szkolne, dokumenty jurysdykcyjne, karty wpisowe do bractw kościelnych, odznaczenia, wyciągi metrykalne Edwarda Najdeckiego legionisty zmarłego w 1920 wraz z dołączoną notatką biograficzną. $1886-1950$.

$38 \times 34,5 \mathrm{~cm}$, bez opr., klb. 60 .

AP 186. 3 notatniki z zapiskami o. Mariana; slb. 56, 72, 41. Kalendarzyk z zapiskami o. Mariana: b. r. klb. 95; 1931 klb. 73, 1933 klb. 110, 1934 klb. 109, 1936 klb. 99, 1941 klb. 112.

$12.5 \times 8 \mathrm{~cm}, \mathrm{pt}$., klb. jw.

A. 187. Skrypty filozoficzne i teologiczne. 1892-1896.

$21 \times 17.5 \mathrm{~cm}$, bez opr., klb. 189.

AP 188. Kazania. 1897--1939.

$22.5 \times 18 \mathrm{~cm}$, bez opr, klb. 738 .

AP 189. Rubrycele opracowane przez o. Mariana od r. 1930 do 1950. (Brak rubrycel z r. 1932, 1938, 1945)

$16.2 \times 11.5 \mathrm{~cm}, 18$ druków jw.

AP 190. Materiały do biografii br. Stefana Rembiszewskiego. Pamiętnik o. Mariana o br. Stefanie pisany od r. 1918 do 1920. $19.5 \times 16.5 \mathrm{~cm}$, pap., klb. 35 .

AP 191. Materiały do biografii br. Stefana Rembiszewskiego opracowane przez o. Mariana, br. Teofila, o. Kosmę Lenczowskiego, o. Konstantego i s. Bogumiłę nazaretankę. 1934-1945. $26.5 \times 20.2 \mathrm{~cm}$, bez opr., klb. 15 .

AP 192. „Kilka słów o bracie Stefanie Rembiszewskim, zaczerpniętych z kroniki Zgrom. SS. Najśw. Rodziny z Nazaretu w Rzymie, 
Krakowie, oraz na podstawie opowiadań starszych sióstr tegoż Zgromadzenia".

$29.5 \times 20.5 \mathrm{~cm}$, bez opr., klb. 12 .

AP 193. Biografia br. Stefana Rembiszewskiego opracowana przez

o. Konstantego Jaronia.

$29.5 \times 20.5 \mathrm{~cm}$, bez opr., klb. 16 .

AP 194. Pamiętnik z podróży do Rzymu w r. 1909.

Dwie jedn. archiwalne.

$12.5 \times 7.5 \mathrm{~cm}$, pap., slb. 38 i 4 .

AP 195. Korespondencja o. Mariana. 1915-1950. Listów 58.

Akielaszek Helena b. d. (2), Caietanus fr. kap. 1924 (1), Chryścińska M. 1944 (2), Czesław o. kap. 1928 (2), Daniel a Vlissingen fr. kap. 1933 (1), Feliks br. kap. 1948 (1), Florian o. kap. 1916 (1), Gabriel o. kap. 1932 (1), Glurówna Maria s. klaryska b. d. (1), Gondulf o. 1928 (1), Haduch ks. T. J. 1919 (1), Honorat o. kap. 1942-1948 (4), Hubicki Agenor 1942 (1), Hübner Karol ks. 1935 (1), Jakub br. 1950 (1), Janusz Helena s, klaryska 1950 (1), Jasiewicz por. 1915 (1), Jeż Mateusz ks. 19191947 (2), Joannes Cantius fr. kap. b. d. (1), Józefa s. nazaretanka 1929 (1), Kasjan fr. kap. 1948 (1), Konstanty o. kap. 19231933 (2), Kozłowski S. 1923 (1), Kramarz K. 1950 (1), Krzyczkowska Olga 1947 (1), Libeltowa b. d. (1), Najdeccy b. d. (1), Najdecki [bratanek] 1945 (2), Najdecki Jan 1947 (4), Najdecka Genowefa b. d. (2), Najdecki Kazimierz 1945 (1), Najdecka Maria b. d. (1), Najdecki Stanisław 1947-1948 (2), Nowakowie 1923-1949 (2), Prokopia s. 1947 (1), Przemysław fr. kap. 1948 (1), Rajmund br. kap. b. d. (1), Różyczko Jadwiga s. klaryska 1950 (1), Strojkówna Józefa s. klaryska b. d. (1), Surmiński 1938 (1), Turowska Anna 1948 (1), Wagner 1944 (1), Witkowscy Tadeuszostwo 1948-1950 (2), jeden list b. a. i d.

$30.5 \times 22 \mathrm{~cm}$, bez opr., klb. 82.

AP 196. Kolekcja obrazów religijnych w liczbie 589 .

AP 197. Laurka imieninowa od sióstr Klarysek z r. 1949.

$30 \times 22.3 \mathrm{~cm}, \mathrm{klb} .2$.

AP 198. Kolekcja widokówek w liczbie 169.

AP 199. Fotografie osobiste o. Mariana, rodzinne, zakonne i różnych osób.

$21 \times 13 \mathrm{~cm}, 126$ fotografii.

AP 200. Album "Domu Sierot" z Prądnika ofiarowany o. Marianowi za dwuletnią opiekę nad zakładem. 1919.

$22.8 \times 31 \mathrm{~cm}$, zawiera 10 fotografii. 
8. Spuścizna o. Czes ł a w a Szu bera (1880-1951)

AP 201. Dokumenty osobiste, legitymacje, świadectwa szkolne, dokumenty jurysdykcyjne, obediencje zakonne, książeczki wpisowe do bractw kościelnych, akta spadkowe, książeczka wkładowa Towarzystwa Zaliczkowego w Krośnie (własność Katarzyny Szuber 1914 i 1916 r.) i inne. 1892-1951.

$33.5 \times 23 \mathrm{~cm}$, bez opr., klb. 143 .

AP 202. „Złote myśli“.

$16 \times 10 \mathrm{~cm}$, pł., klb. 10 .

A.P 203. "Teologia pastoralna. Wykłady w Studium Teologicznym OO. Kapucynów w Krakowie 1935". [Skrypt powielany].

$21.5 \times 17.5$ bez opr., slb. 78 .

AP 204. "WYkaz wygłoszonych kazañ". [1902-1951].

$15.3 \times 9 \mathrm{~cm}$, pł., klb. 22 .

AP 205. „Wykaz wygłoszonych rekolekcji i misji”. [1906-1951].

$16 \times 9.5 \mathrm{~cm}, \mathrm{pk}$., klb. 58 .

AP 206. "Wykaz wygłoszonych rekolekcji i misji".. [1933-1951]. $16 \times 10 \mathrm{~cm}$, pł., klb. 11 .

AP .207. „Kazania niedzielne". $25 \times 17.5 \mathrm{~cm}$, bez opr., klb. 202.

AP .208. „Kazania świąteczne". $80.5 \times 21.5 \mathrm{~cm}$, bez opr, klb. 688.

AP 209. "Kazania misy.jne i rekolekcyjne". $22 \times 17.5 \mathrm{~cm}$, bez opr, klb. 724 .

A'P 210. "Konferencje duchowne dla księży i zakonników". $32 \times 24 \mathrm{~cm}$, bez opr., klb. 346 .

AP 211. "Nauki rekolekcyjne dla tercjarzy". $20 \times 16.5 . \mathrm{cm}$, płpł., klb. 470 .

AP 212. "Kazania pasyjne". $21 \times 17.5 \mathrm{~cm}$, bez opr., klb. 24 .

AP 213. "Kazania maryjne". $23 \times 21 \mathrm{~cm}$, bez opr., klb. 372 .

AP 214. "Nowenna do św. Teresy od Dzieciątka Jezus". "Nowenna do Dzieciątka Jezus“. [1926-1931]. $21.5 \times 17.5 \mathrm{~cm}$, bez opr., klb. 83.

AP 215. Sprawozdanie z wizytacji kanonicznych SS. Sercanek, Felicjanek oraz instrukcja dla wizytatorów zgromadzeń żeńskich w Archidiecezji Krakowskiej. 1935.

$34 \times 21 \mathrm{~cm}$, bez opr., klb. 46. 
A.P 216. Sprawy beatyfikacji sług Bożych: o. Rafała Kalinowskiego, arcybpa Józefa Bilczewskiego i m. Marii Angeli Truszkowskiej. $1936-1949$.

$30.5 \times 22$, bez opr., klb. 60 .

AP 217. Oryginalne prace o. Czesława. 1927-1951.

$34 \times 21 \mathrm{~cm}$, bez opr., klb. 182.

AP 218. Tłumaczenia o. Czesława.

$30.5 \times 21.5 \mathrm{~cm}$, bez opr., klb. 48 .

AP 219. „Felder Hilarin o.: Ideały św. Franciszka z Asyżu. Przetłumaczył o. Czesław Szuber kapucyn. Kraków 1938. T. I i II".

$29.8 \times 20.7 \mathrm{~cm}$, pł., t. I - slb. 285 , t. II - slb. 249.

AP 220. Odbitka szczotkowa "Ideałów św. Franciszka" z korektą o. Czesława.

$62 \times 23.7 \mathrm{~cm}$, bez opr., klb. 114.

AP 221. Projekt okładki do "Ideałów św. Franciszka" wykonany przez Jadwigę Rymarównę.

$34 \times 24 \mathrm{~cm}$, bez opr., klb. 3 .

AP 222. Kalendarzyki amerykańskie z zapiskami o. Czesława. Jeden z r. 1923, drugi z 1928.

$11.3 \times 7 \mathrm{~cm}$, sk., klb. 71 i 113 .

AP 223. Amerykańskie adresy. Koperty $\mathrm{z}$ adresami ofiarodawców na budowę kościoła OO. Kapucynów w Zamarstynowie. 19281929.

$19 \times 17 \mathrm{~cm}$, bez opr., klb. 389 .

AP 224. Ksiega kasowa o. Czesława z czasów misji w Stanach Zjednoczonych A. P. Obejmuje również protokół przesyłek pieniężnych do kasy prowincji i do poszczególnych klasztorów, spis odprawionych intencji oraz wykaz wygłoszonych kazań i konferencji. $1928-1929$.

$23 \times 14.5 \mathrm{~cm}$, pł., sib. 300 .

AP 225. 14 przewodników po miastach Stanów Zjednoczonych, Włoch, Francji i Budapesztu. 10 albumów różnych miast. 1927-1931.

AP 226. Kongres eucharystyczny w Budapeszcie w r. 1938. 5 druków.

AP 227. "Związek Haczowiaków". [Akta i korespondencja, 1910-1947].

$37 \times 24 \mathrm{~cm}$, bez opr., klb. 131 .

AP 228. Pamiętnik. (Tylko początek). 1950.

$29.5 \times 21 \mathrm{~cm}$, bez opr., klb. 6 .

A.P 229. "Pamiętnik z podróży do Ameryki w r. 1928".

$15.5 \times 9.5 \mathrm{~cm}$, pł., klb. 17 .

AP 230. Korespondencja o. Czesława . Listów 31.

List - autor nieodczytany 1928 (1), Archanioł kap. 1937 (1), 
Balla Anna 1925 (1), Felicjanki - Buffalo i Lodi USA (3), Gra-. sela A. dyr. 1938 (1), Honorat o. kap. 1936 (1), Kornel o. kap. 1949 (1), Ministerstwo Skarbu 1932 (1), Kurski Adam 1942 (2), Lepkowski Wincenty prof. 1931 (1), Parafianie Parafii św. Stanisława w Nashua USA 1928 (1), Orange W. b. d. (6), Rymar Stanisław dr 1936 (1), Rusin L. ks. 1938-1939 (4), Salvator o. kap. 1937 (1), Stokowy Barnaba o. franciszk. 1948 (1), Tekla 1929 (1), 3 zaproszenia oficjalne 1933 (3).

30.5 x $22 \mathrm{~cm}$, bez opr.

AP 231. Kolekcja widokówek w liczbie 29.

AP 232. Fotografie: osobiste o. Czesława, rodzinne, zakonne i różnych osób. $25.5 \times 22 \mathrm{~cm}, 128$ fotografii.

9. Spuścizna o. Konstantego Jaronia (1873-1952)

AP 233. Dokumenty osobiste: legitymacje, metryka, świadectwo święceń, instrumenty jurysdykcyjne. 1885-1951.

$35 \times 21.5 \mathrm{~cm}$, bez opr., klb. 46 .

AP 234. Skrypty filozoficzne i teologiczne. 1891-1896.

$21 \times 17 \mathrm{~cm}$, bez opr., klb. 1068.

AP 235. "Spis misji, rekolekcji i kazań przygodnych". [1902-1951].

$21 \times 16.5 \mathrm{~cm}$, sk., slb. 246 .

AP 236. Kazania niedzielne. 1900-1950.

$21.5 \times 17.5 \mathrm{~cm}$, bez opr., klb. 844 .

AP 237. "Kazania świąteczne, maryjne, o świętych Pańskich, okolicznościowe" [m. i. na powrót Kapucynów do Lublina - 1.VIII.1919, streszczenie kazań i przemówień, nowenny. 1899-1951].

$21 \times 17.5 \mathrm{~cm}$, bez opr., klb. 631 .

AP 238. "Okruszyny misyjne. Rekolekcje dla studentów”. [1911-1938]. $21 \times 17.5 \mathrm{~cm}$, bez opr., klb. 55.

AP 239. Zbiór mniejszych prac i artykułów: „W 230 rocznice odsieczy Wiednia - Marek d'Aviano, Rzeszów 1916", druk k. 1-8. „Summula vitae famulae Dei Floridae“ k. 9-10. „Krótki żywot św. brata Konrada kapucyna“ k. 11-25. „Sp. o. Konstanty Żukiewicz dominikanin, największy mariolog polski $\mathrm{w} w$. XX" k. 26-42. 1916-1949.

$33.5 \times 22 \mathrm{~cm}$, bez opr., klb. 42 .

AP 240. "Br. Stefan Rembiszewski kapucyn".

$20.5 \times 14.5 \mathrm{~cm}$, pap., klb. 39 . 
AP 241. „Pierwsza uroczysta beatyfikacja świętego syna Sardynii czyli błogosławiony Ignacy z Lakoni braciszek zakonu oo. kapucynów. Napisał o. Konstanty z Głogowa".

$20 \times 16.5 \mathrm{~cm}$, płpł., slb. 154 .

Rps gotowy do druku. Posiada aprobate zakonna i Kurii Biskupiej Przemyskiej z r. 1943.

AP 242. „Pamiętnik". [Fragmenty. 1885-1915].

$22 \times 17 \mathrm{~cm}$, bez opr., klb. 18 .

AP 243. Korespondencja o. Konstantego. 1916-1951. Listów 46.

Barda Fr. bp. 1945 (1), Baziak E. arcybp. 1949 (1), Bronisław o. kap. 1950 (6), Czesław o. kap. 1951 (1), Dominikanki siostry 1949 (6), Franciszek o, bernardyn 1949 (1), Franciszkanki siostry 1950 (13), Gommaire o. kap. 1948 (1), Joseph Anton o. kap. 1947 (2), Józef o. karm. b. d. (1), Józefitki siostry 1950-1951 (2), Leon o. kap. 1948 (1), Modest o. kap. 1951 (1), Paździor Jakub o. domin, 1949 (1), Serafitki siostry 1951 (2), Wolfrid o. kap. 1949 (2), Wołek Lucjan o. domin. 1949 (1), bez autora 1916 i b. d. (4). $30 \times 21 \mathrm{~cm}$, bez opr., klb. 69 .

AP 244. "Ganter Hugo Pfarrer: Was denkt euch von Konnersreuth? Badenia in Karlsruhe, 1936" k. 1-36.

„Kreppeldt Fulgenz P.: Der selige Ignatius von Laconi, Kapuzinerlaienbruder $(1701-1781)^{\prime \prime}$ k. $1-64$.

30.5 x $21.5 \mathrm{~cm}$, bez opr., klb. jw.

AP 245. Fotografie: osobiste, rodzinne, zakonne i inne. $18 \times 12.5 \mathrm{~cm}, 152$ fotografie.

10. Spuścizna o. Honorata Jed lińskiego (1869-1952)

AP 246. Dokumenty osobiste. 1882-1952.

$30 \times 21.5 \mathrm{~cm}$, bez opr., klb. 22 .

AP 247. "Księga mszalna i wykaz nauki religii”. [1902-1908].

$16 \times 9.2 \mathrm{~cm}$, pap., klb. 27.

AP 248. Kazania." 1892-1950.

A.P 249. Działalność duszpasterska: wykaz uczniów, parafian, adresy wołyniaków. 1943-1950.

$21 \times 16.8 \mathrm{~cm}$, bez opr., klb. 70 .

AP 250. "Silva rerum".

$24.3 \times 19.5 \mathrm{~cm}, \mathrm{pk} ., \mathrm{klb} .40$.

AP 251. Korespondencja o. Honorata. 1932-1952. Listów 43.

Alojzy o. kap. 1951 (1), Anioł o. kap. 1943-1948 (7), Bernard

o. kap. 1948 (1), Bętkowska Teresa 1947 (1), Bielińska Maria 
1951-1952 (2), Chyliński Franciszek 1910 (1), Gabriel o. kap. b. d. (1), Grzegorczyk Piotr 1952 (2), Jarmoliński Piotr 1951 (1), Jedliński Stanisław 1951-1952 (7), Kapuścińscy 1949 (1), Kornel o. kap. 1951 (1), Konstanty o, kap. 1946 (1), Konopka J. ks. 1935 (1), Kwarta ks. USA b. d. (1), Łazarz br. kap. b. d. (1), Markiewicz Anna Walenta 1951 (1), Marian o. kap. 1950 (1), Malinowski Jan 1949 (1), Naumowicz Bolesław b. d. (1), Piotrowska Emilia 1951 (1), Piotrowska Józefa 1951 (1), Rafał o. kap. b. d. (1), Somrat St. 1950 (1), Wagner 1952 (1), Wójtowiczowa Michalina 1951-1952 (2), Zielińscy J. 1951 (1), bez nadawcy 1932 (1).

$30 \times 21 \mathrm{~cm}$, bez opr., klb. 52 .

AP 252. Fotografie osobiste, zakonne i inne.

$16.5 \times 11 \mathrm{~cm}, 47$ fotografii.

11. Spuścizna o. Gabriel a Banasia (1890-1953)

AP 253. Kazania i materiały do kazań. 1912-1938.

$22 \times 17.5 \mathrm{~cm}$, bez opr., klb. 511 .

AP 254. Kazania różne. 1920-1948.

$21.5 \times 17 \mathrm{~cm}$, bez opr., klb. 303.

AP 255. Kazania misyjne. 1920-1949.

$22 \times 18 \mathrm{~cm}$, bez opr., klb. 462 .

AP 256. "Dziennik“. [1917-1920].

$20 \times 16.5 \mathrm{~cm}$, pap., klb. 106 .

12. Spuścizna o. Inn oc en tego Trojan owskiego (19151955)

AP 257. Dokumenty osobiste. 1924-1954.

$35 \times 22 \mathrm{~cm}$, bez opr., klb. 21 .

AP 258. Notes klasyfikacyjny.

$14.5 \times 10 \mathrm{~cm}$, pł., klb. 21.

AP 259. Szkice kazań, dyspozycje kazań, kazania, konferencje, materiały do kazań i konferencji.

$21 \times 17 \mathrm{~cm}$, bez opr., klb. 618 .

AP 260. Korespondencja o. Innocentego.

Ciechocińska M. 1952 (1), Ernestyna s. serafitka 1951 (1), Janka [siostrzenica] 1951 (10), Kowalik Krystyna 1954 (1), Róża

s. 1954 (1), Turno Maria 1954 (1).

$30 \times 21 \mathrm{~cm}$, bez opr., klb. 18.

AP 261. "Turowska Anna: Poezje".

$38 \times 23 \mathrm{~cm}$, bez opr., klb. 96. 
13. Spuścizna o. Brunona Moskala (1885-1957)

AP 262. Dokumenty osobiste. 1901-1920.

$34.2 \times 25 \mathrm{~cm}$, bez opr., klb. 12 .

AP 263. Kazania. 1917-1952.

$20 \times 18 \mathrm{~cm}$, bez opr., klb, 828 .

14. Spuścizna o. Ernes ta $Ł$ an u chy (1914-1959)

AP 264. Dokumenty osobiste. 1926-1959.

$34 \times 24 \mathrm{~cm}$, bez opr., klb. 71 .

AP 265. Skrypty filozoficzne. 1945.

$34 \times 21.5 \mathrm{~cm}$, bez opr., klb. 111.

AP 266. "Kazania na niedziele". [1939-1950].

$26.5 \times 20.5 \mathrm{~cm}$, pł., slb. 104 .

AP 267. „Kazania świąteczne i przygodne". [1939-1956]. $26.5 \times 20.5 \mathrm{~cm}$, pł., slb. 298 .

AP 268. "Kazania dogmatyczne". [1939-1956].

$26.5 \times 20.5 \mathrm{~cm}, \mathrm{pł}$, slb. 244.

AP 269. "Kazania misyjne i rekolekcyjne". [B. d.]. $26.5 \times 20.5 \mathrm{~cm}$, pł., slb. 526 .

AP 270. "Matka Najświętsza". [Kazania. 1939-1956]. $26.5 \times 20.5 \mathrm{~cm}, \mathrm{pł}$, slb. 158 .

AP 271. "Konferencje franciszkańskie". [1939-1956]. $26.5 \times 20.5 \mathrm{~cm}, \mathrm{pł}$., slb. 351 .

AP 272. "Kazania nowe". [1956-1959]. $30.5 \times 22 \mathrm{~cm}$, pł., klb. 53.

AP 273. „Przemówienia prowincjalskie“. [1956-1959]. $33 \times 23 \mathrm{~cm}, \mathrm{pł}$., klb. 21.

AP 274. „Dwoistość uczuć u św. Tomasza z Akwinu. Dwustopniowość. $1945^{\prime \prime}$.

Praca magisterska. .

$29.5 \times 21.3 \mathrm{~cm}$, bez opr., klb. 22 .

AP 275. "Wstęp do filozofii. Wykłady w Wyższym Instytucie Wiedzy Religijnej w Gdańsku". [1947].

$30.5 \times 23 \mathrm{~cm}$, bez opr., klb, 22 .

AP 276. Album fotograficzny. 1934-1945.

$38 \times 25.5 \mathrm{~cm}$, sk., 113 fotogx. +326 fotogr. luźnych.

15. Spuścizna o. Kosmy Lencz owskiego (1881-1959)

AP 277. Dokumenty osobiste. 1894-1959.

$34 \times 25 \mathrm{~cm}$, bez opr, klb. 57 .

AP 278. Dokumenty i akta legionowe. Wycinki z czasopism i dzienników. 1914-1939.

$38.5 \times 26 \mathrm{~cm}$, bez opr., klb. 134 . 
AP 279. Dyplomy i legitymacje odznak, odznaczeń, Krzyża Niepodległości oraz Krzyża Oficerskiego Orderu Odrodzenia Polski. $1916-1938$.

$40.5 \times 38.5 \mathrm{~cm}$, bez opr., klb. 10 .

AP 280. "Szkice odprawionych przez siebie rekolekcji". [O. Wacław 1902-1904].

$21 \times 17 \mathrm{~cm}$, bez opr., klb. 13 .

AP 281. "Kazania niedzielne i świąteczne". [1907-1939].

$22 \times 19 \mathrm{~cm}$, bez opr., klb. 645 .

AP 282. "Kazania okolicznościowe o Najśw. Marii Pannie i Świętych". [1914-1939].

$23.5 \times 18 \mathrm{~cm}$, bez opr., klh. 247 .

AP 283. "Kazania okolicznościowe". [1914-1939].

$22 \times 18.5 \mathrm{~cm}$, bez opr., klb. 169 .

AP 283a. „Kazania i przemówienia legionowe". [1914-1939].

$37 \times 22.5 \mathrm{~cm}$, bez opr., klb. 28 .

AP 284. "I-szy dziennik czynności urzędu duszpasterskiego II pułku I brygady Piłsudskiego (5 pułk) od 1.X.1915-1916". [Kilka piosenek legionowych. 1915-1916].

$12.8 \times 7.8 . \mathrm{cm}$, bez opr., klb. 18 .

AP 285. „Kataster grobów na pobojowiskach I Brygady Legionów Polskich". [Inwentarz grobów sporządzonych przez o. Kosmę Lenczowskiego kapelana Legionów Polskich. 1914-1916].

$23.5 \times 34.5 \mathrm{~cm}$, pap., klb. 5 .

AP 286. „Opis grobów na pobojowiskach I Brygady Leg. Polskich zwiedzanych przez ks. Kosmę Lenczowskiego kapelana Leg. Polskich". [1914-1916].

$17.7 \times 22.3 \mathrm{~cm}$, bez opr., slb. 13 .

AP 287. "Spis poległych legionistów czwartaków i I-szej Brygady". [Dołączone plany cmentarzy. 1915-1916].

$21 \times 16.5 \mathrm{~cm}$, pap., klb. 13.

AP 288. Notes z pięczęciami urzędów i jednostek Legionów Polskich oraz autografy urzędników L. P. i legionistów. 1914-1918.

$8 \times 14.2 \mathrm{~cm}$, pap., klb. 79 .

AP 289. Notes z pieczęciami urzędów i jednostek L. P. oraz autografy urzędników L. P. i legionistów. 1914-1918.

$9.5 \times 15.8 \mathrm{~cm}, \mathrm{pl}$., klb. 54 .

AP 290. Notes z pieczęciami urzędów i jednostek L. P. oraz autografy urzędów L. P. i legionistów. 1914-1918.

$16.5 \times 10.5 \mathrm{~cm}$, pap., klb. 51 .

AP 291. Autografy legionistów. 1917. K. 1-26. Autografy uczestników jubileuszu 50-lecia kapłaństwa o. Kosmy w r. 1955. K. 27-47. $8 \times 16 \mathrm{~cm}$, pap., klb. 47 . 
AP 292. Jubileusz 50-lecia kapłaństwa o. Kosmy Lenczowskiego. Przemówienia i wiersze. 1955.

$30 \times 21 \mathrm{~cm}$, pap., klb. 22 .

AP 293. "Moja pielgrzymka do Ziemi Swiętej w r. 1914". [Napisane w r. 1957]. $20.5 \times 14.5 \mathrm{~cm}$, pap., klb. 20.

AP 294. „Pamiętnik o. Kosmy Lenczowskiego kapucyna, kapelana I Brygady Legionistów Polskich. Zeszyt 1". [1914-1915]. $19.8 \times 15.3 \mathrm{~cm}$, pap., slb. 114 .

AP 295. „Pamiętnik o. Kosmy Lenczowskiego kapucyna, kapelana I Brygady Legionistów Polskich. Zeszyt 2". [1915—1945]. .

Oryginał pamiętnika zaginał we Lwowie w czasie drugiej wojny światowej. Obeeny tekst odtworzył autor pamiętnika z dokumentów, zapisków i pamięci po $x$. 1945.

$20.5 \times 15 \mathrm{~cm}$, pap., slb. 182 .

AP 296. "Niemiłe przygody moje w listopadzie i grudniu 1939 r. à் do 12 maja 1940 r.". [Uzupełnienie pamiętnika].

$20.5 \times 14.5 \mathrm{~cm}$, pap., klb. 57.

AP 297. Korespondencja o. Kosmy Lenczowskiego. 1914-1958. Listów 233.

Abanowicz K. 1953-1956 (3), Alojzy o. kap. 1916 (2), Andruszewski Jan 1915 (1), Baziak Eugeniusz arcybp. 1955 (1), Baygerowie 1927-1938 (12), Benedykt br. kap. 1916 (1), Benedyktynki 1917 (1), Brandt A. M. 1955 (2), Brykner Józef 1918 (1), Bryła Tadeusz 1939 (3), Bukowscy 1916 (1), Cieślikowski Wacław 1955-1956 (3), Chmielowa z Rosiewiczów Janina 1955 (1), Chodzicka Maria 1915 (3), Chrobakiewicz Jan ks. 1955 (1), Czesław o. kap. 1915-1916 (3), Czołowski Stanisław 1943 (1), Damian o. kap. 1916 (1), Domańska Fr. 1921 (1), Dooner Wiktoria 1955 (1), Dziura Wincenty 1939 (1), Dworska Stanisíawa 1947 (1), Efrem o. z Kcyni kap. art. mal. i rzeźbiarz b. d. (4), Felicjan o. kap. 1915 (1), Florian o. kap. 1915 -1816 (2), Folfasiński Piotr ks. 1939 (1), Godziszewski Włodzimierz Siemionow prof. 1916 (2), Gorgoń Julia 1915 (1), Gorgoń Kazimierz 19161917 (2), Gorgoń Stefania 1945 (1), Gorgoń Teresa 1939-1956 (4), Góyska Alina 1918-1919 (5), Głąbiński Piotr 1916 (1), Grudniok Fr. ks. 1955 (1), Grząkowie A. I W. 1955 (1), Hajec por. 1916 (2), Honorat o. kap. 1948 (1), Janiewski Grzegorz ks. 1918 (2), Jankowska Aniela 1915 (1), Jankowski J. ks. 1916 (5), Jaworska Aniela 1939 (1), Jeziorski Michał 1915 (1), Jirsa ks. 1916 (1), Józef o. kap. 1955 (1); 
Kamiński St. ks. 1916 (4), Komocki M. 1916 (1), Kapucyni Kraków 1915 (1), Kaszuba Maria 1955 (1), Katolickie Stow. Młodzieży Ż. b. d. (1), Kawa Mieczysław b. d. (1), Kazik 1916 (1), Kołodziejska Leonarda 1947 (6), Kołodziejski Karol 19151918 (2), Kołodziejski Teofil 1916--1918 (6), Komitet Obchodu Rocznicy Bitwy Kościuszkowskiej w Słomnikach 1916 (1), Komitet jak wyżej w Racławicach 1916 (4), Konstanty o. kap. 1915 -1916 (3), Kozicki St. 1939 (1), Kicki Jan por. 1916 (2), Kisiała Adam [Jan Duklan br, kap.] 1916 (4), Korpet Wł. 1916 (1), Kowalczyk J. J. 1918 (1), Krechowiecki Jan (1), Krzysztofowicz Henryk 1958 (1), Kukulski Józef 1916 (1), Leonarda s. 1917 (4), Leruch R. 1916 (1), Lewicki Wł. 1916 (1), Lewicki St. 1944 (1), Liberowie 1955 (1), Liga Kobiet Kamińsk 1916 (1), Łysakowska Maria 1916 (1), Łuczyńska St. 1916 (2), Euczyński Jan 1916 (1), Makiel Józef 1939-1958 (3), Marceli 1916 (1), Marian o. kap. 1915-1916 (6), Maria s. klaryska 1955 (1);

Pakosz Innocenty o. kap. 1915 (1), Panaś ks. kapelan Komendy Legionów 1916 (8), Piekarska Felicja 1955 (1), Pieracki Bronisław minister 1933 (1), Poniński A. ks. 1916 (1), Potkańska H. 1915 (1), Pius o. kap. 1918 (1), Pyzikiewicz Hieronim b. d. (2), Ochał Laurenty o. kap. 1958 (1), Olszowska Stefania 1916 (2), Ołłowicz 1916 (1), Radzyński R. 1955 (1), Rogowska Maria b. d. (1), Rogowski Jan 1916 (3), Rozegnał Michał 1915-1916 (3), Różycka 1916 (1), Ruszak Jakub br. kap. 1955 (1), Skuciński M. 1916 (3), Smyrski Karol 1917 (1), Starzyk 1916 (4), Steinowa Natalia 1916 (1), Studencki Jan 1916 (3), Szeleżnik 1916-1917 (3), Szymankiewicz J. T. 1949 (2), Tadeusz o. kap. 1955 (1), Tatkowski Rudolf 1916 (3), Tomaszkiewicz Jan ks. 1914 (1), Toporczyk, Błaszczyński i Trapszo Tadeusz 1916 (1), Turkowski Maurycy ks. 1955 (1), Urbański 1955 (8), Wagner 1925 (1), W. Kazimierz 1916 (1), Wilamowski M. ks. 1915-1925 (3), Wilowski Marian 1916 (1), Wnękowa Antonina b. d. (1), Wolańska Maria b. d. (1), Zamarska Maria 1917 (1), Zawadzki W. ks. 1917 (1), Zarych Wacław o. kap. 1916 (2), Zygmunt o. kap. 1915-1917 (2), Żak Wł. ks. 1955 (2), Żelawski Józef b. d. (1), Żytkiewicz Stanisław ks. 1916 (1).

$34 \times 23 \mathrm{~cm}$, bez opr., klb. 338 .

AP 298. "Kazania ks. Antoniewicza".

Na 1 karcie uwagi o. Kosmy: „Przy końcu 19 wieku umierał ks. Antoniewicz. Zaopatrujacemu go św. Sakramentami ks. Stachurskiemu zlecił on chory wydać drukiem jego kazania. Ks. Stachurski tego nie doko- 
nał. Część tych kazań wpadła w me ręce. Oto te. Ks. Stachurski był proboszczem w Trzcianie ad Rzeszów".

$26 \times 21.5 \mathrm{~cm}$, bez opr., klb. 197.

AP 299. Album fotografii. Kapucyni w charakterze kapelanów armii austriackiej, fotografie różne, konsekracja kościoła w Zamarstynowie. 19 akwarel art. mal. Eugeniusza Dołganowa z Niżnego Nowogrodu ilustrujących pracę o. Kosmy w Legionach (1921). Fotografie o. Kosmy w Legionach Polskich.

$49.5 \times 31 \mathrm{~cm}$, płsk., klb. 27, fotogr. 101.

AP 300. Album legionowy. 1914-1918.

$22 \times 14,5 \mathrm{~cm}$, pł., klb. 37 , fotogr. 167 .

AP 30.1. Fotografie legionowe, rodzinne, zakonne i inne.

$19 \times 13 \mathrm{~cm}$, bez opr., fotogr. 225 .

16. Spuścizna o. In n oc ent eg o Pakos za (1892-1925)

AP 302. "Notes 1907/8. Pakosza Stanisława ucz. IV C kl. gimn. w Sanoku". [1907-1914].

$14.5 \times 9 \mathrm{~cm}$, sk., klb. 56 .

17. Spuścizna o. Damiana Węg la (ur. 1881)

AP 303. "Zapiski o. Damiana Węgla". [Listy do o. Damiana, wyciniri z gazet, rachunek. 1914-1915].

$20 \times 16.2 \mathrm{~cm}$, pap., slb. 106 .

18. Spuścizna br. Te ofila Kowalika (1866-1944)

AP 304. Książka kwestarska i zapiski br. Teofila Kowalika. Różne zapiski, przysłowia, sentencje, wiersze i inne. 1931-1939.

$19.2 \times 12 \mathrm{~cm}$, płpl., slb. 202.

AP 305. "Wykaz zmarłych zakonników w kapucyńskich konwentach". [Różne zapiski].

$19.2 \times 12 \mathrm{~cm}$, płpł., klb. 56.

AP 306. „Rozmaitości”. [Historia krakowskich kościolów i różne wspomnienia. 1933-1940].

$19.8 \times 15.5 \mathrm{~cm}$, pap., slb. 278.

19. Spuścizna o. Gerarda Rysza (ur. 1892)

AP 307. "Pamiętnik". [1919].

$20 \times 16.5 \mathrm{~cm}$, bez opr., klb. 8 .

AP 308. Zapiski z okresu prowincjalstwa. 1937-1939.

$16 \times 10 \mathrm{~cm}, \mathrm{pl}, \mathrm{slb} .377$. 
AP' 309: Korespondencja 'o' Gerarda. 1917-1957. Listów 56. Adalbert o. Budapeszt 1939 (1), Gunia Franciszek ks. s. 1944 (1), Foryś Józef ks. 1917 (1), Janocha Florian o. b. d. (1), Jaroń Konstanty o. 1917-1919 (4), Kocjan Otto o. Skofja Loka 1940 (1), Korecki Eugeniusz prof. 1937 (1), Laurean o. Palestyna b. d. (1), Mayerhofer Franz 1947 (1), Michiels Gomar o. Heerentals 1952 (1), Nowak Anatol bp. 1931-1933 (3), Pakosz Innocenty o. b. d. (2), Salvator o. Olten 1942 (1), Sapieha A. bp. b. d. (1), Stepek Bronisław o. 1925 (1), Szczepan br. Loreto 1955-1957 (3), Tomaka W. bp. 1934 (1), Wolfrid o. Luzern 1940-1944 (30), $33.5 \times 23 \mathrm{~cm}$, bez opr., klb. 59 .

AP 310. Korespondencja o. Kasjana Wolaka z siostrą Heleną Grzeszczyk. „Obrazki z Dachau, Dokument nr 12, Zeznania ks. Stanisława Wolaka". 1942-1944.

$22.5 \times 15.5 \mathrm{~cm}$, bez opr., klb. 50, 25 listów.

AP 311. "Despinoix Apolinary: Z kapucyńskiej niwy". [Rozwadów 1933. Przeróbka dzieła Ilga pt. Geist des heiligen Franciscus].

$21 \times 17 \mathrm{~cm}$, bez opr., klb. $326+16$.

AP 312. 7 akwarel pędzla art. mal. Barwickiego.

$28 \times 21 \mathrm{~cm}, 7$ akwarel.

AP 313. 13 akwarel art. mal. Barwickiego (w tym jedna M. Hołyńskiego - 1942).

$17 \times 12.5 \mathrm{~cm}$, pł., 13 akwarel.

AP 314. Sztambuch. 15 akwarel art. mal. Barwickiego, kompozycja B. Wallek-Walewskiego "Ave Maria" z r. 1936, wiersz A. Despinoix z r. 1932 oraz dwa wiersze o. Marka Kolbuszewskiego. $16.5 \times 12 \mathrm{~cm}, \mathrm{p} ł, \mathrm{klb} .19$.

AP 315. Albumy fotograficzne.

\section{KOLEKCJE ARCHIWUM PROWINCJI KRAKOWSKIEJ}

1. Akta i materiały dotyczące Prowincji Polskiej OO. Kapucynów i różnych jej klasztorów.

APP 1. Obediencje i dokumenty kwestarskie klasztorów prowincji polskiej. Familie konwentów z lat 1835-1858. Listy papieskie, biskupie, władz świeckich oraz odezwa cara do biskupów polskich.

Alsta luźne, $38.5 \times 23.3 \mathrm{~cm}$ i mniej, bez opr., knlb. 190 .

$\triangle \mathrm{PP}$ 2. "Annalium Provinciae Poloniae Patrum Capuccinorum Tomus III. Inchoatus anno 1833". [1833-1889]. Odpis reczny z orvg nału zrajdujacego sie w Archiwum Prowincji Warszawskiej OO. Kapucynów sporzạdzony w r. 1957. $29.8 \times 20.8 \mathrm{c:n}$, pl., slb. 269 , knlb. 5 , 
APP 3. "Historia Conventus et Ecclesiae Patrum Capuccinorum Eomżensis Anno Domini 1814 incepta. Tomus II sub Guardianatu Admodum Venerandi Patris Georgii a Duchny". [1814-1840].

Odpis (maszynopis) z oryginału znajdującego sie w Archiwum Klasztoru 0O. Kapucynów w Łomży sporządzony w r. 1956 przez o. Alfonsa z Lublina, $29.5 \times 20.7 \mathrm{~cm}$, plpł., slb. 332 .

A.PP 4. „O. Honorat z Białej Podlaskiej, kapucyn. Oprac. Elekta Muśnicka i Jolanta Muśkiewicz. Warszawa 1952".

Maszynopis, $30 \times 20.5 \mathrm{~cm}$, płpł., slb. 292.

APP 5. „Kazania na święta Najświętszej Maryi Panny pisane w Lubartowie przez "Księdza Jakuba Kapucyna w roku 1814".

$15.7 \times 10 \mathrm{~cm}$, pap., kart zapis. 10 .

2. Akta prowincji ruskiej czyli roksolańskiej i materiały dotyczące tej prowincji

APR 1. "Akta Capitulorum et Congregationum Ordinis Fratrum Minorum Capuccinorum Provinciae Russiae". [1827-1875].

„Uwaga: „Hic liber ex Conventu Vinnicensi a P. Casimiro 1892 Cracoviem delatus".

$37.6 \times 23.5 \mathrm{~cm}$, płpł., slb. 129.

APR 2. „Giżycki Marek Jan [pseud. Wołyniak]: Nieco faktów fragmentarycznych o Kapucynach w. Polsce. (Prowincya Roxolana)".

Rps zakupiony przez o. Czesława Szubera.

$16.7 \times 20.7 \mathrm{~cm}$, bez opr., knlb. 160 .

Część druga

\section{ARCHIWA POSZCZEGÓLNYCH KLASZTORÓW KAPUCYŃSKICH}

\section{ARCHIWUM KLASZTORU W KRAKOWIE}

\section{Historia klasztoru}

Klasztor krakowski jest drugą po Warszawie placówką kapucyńską w Polsce.

Papież Innocenty XI w breve wydanym 10 września $1680 \mathrm{r}$. zezwolił zakonowi na założenie dwóch hospicjów w Warszawie i Krakowie xa zgodą miejscowych ordynariuszy. Biskup krakowski Jan Małachowski wyraził zgodę na erekcję konwentu w Krakowie dnia 20 stycznia $1634 \mathrm{r}$. Papież. Innocenty XII w breve z dnia 1 grudnia $1691 \mathrm{r}$. zgodził się na zainiane hospicjów $w$ formalne konwenty z 12 zakonnikami.

Pierwszymi fundatorami konwentu krakowskiego byli Hieronim Luhomirski marszałek w. koronny i jego siostra Krystyna Potocka, żona 
Feliksa wojewody krakowskiego. W latach 1683-1685 przekazali oni o. Jakubowi z Rawenny Pałac Spiski przy rynku. Legat ten zatwierdził sejm warszawski dnia 23 lutego $1685 \mathrm{r}$.

Po załatwieniu formalności prawnych przybyli do Krakowa pierwsi kapucyni 20 lipca 1695 r. i znależli gościnę w domu ks. Jana Stachowskiego rektora kościoła św. Piotra na Garbarach. Mieszkańcy miasta, a zwłaszcza rodziny włoskie lub włoskiego pochodzenia, przyjęli serdecznje zakonników. Za poradą dr Bergamino wybrano ogród rajcy kra. kowskiego Kazimierza Cantelli na miejsce pod fundację. Obiekt ten powiększono zakupionymi działkami ziemi od OO. Karmelitów na Piasku i micszczan krakowskich Franciszka Cezarego i Roberta Forbesa.

Rudową kierował Jan Ceroni architekt z Warszawy. Dnia 10 kwietnia 1696 r. bp Małachowski poświęcił kamień węgielny. Kościół wznos7ono w stylu toskańskim pod wezwaniem Zwiastowania N.M.P. ze składek różnych ofiarodawców. Składki wystarczyły tylko na zakup placu i założenie fundamentów. Funduszów do dalszej budowy zabrakło. Z pomocą przyszedł dopiero Albrecht Dembiński chorąży zatorski, który zobowiązał się prowadzić budowe do końca. Po zgromadzeniu odpowiedıiej ilości materiału budowlanego, architekt Marcin Pellegrini zakonczył w r. 1699 . budowę. Dnia 3 października 1699 r. odbyło się uroczyste przekazanie kościoła i konwentu zakonnikom. Koszt budowy całego obiektu wyniósł 19.305 złp. Aktu konsekracji kościoła dokonał w dniu 13 maja 1703 r. bp Kazimierz Lubieński sufragan krakowski.

Albrecht Dembiński ufundował również w latach 1712-1719 Domek Loretański. W r. 1720 wzniósł jeszcze biblioteke, do której ofiarowali s, woje zbiory: bp Łubieński, ks. Weyss kapelan biskupa, Eligiusz Wadowski i inni obywatele miasta.

Dalsza rozkudowa klasztoru i kościoła według projektów architekta Zygmunta Gawlika nastąpiła w latach 1927-1933 i 1937-1939. Charakter zabytkowy obiektu został zachowany.

Wyposażenie wnętrza kościoła jest bardzo ubogie. Zwraca uwagę "Zwiastowanie" - kopia obrazu Dandiniego z kościoła serwitów we Florencji, „św. Franciszek" Czechowicza, krucyfiks w chórze zakonnym, figura św. Feliksa oraz łaskami słynąca M. B. Loretańska - dzieła o. Franciszka z Pescji. W kaplicy Pana Jezusa słynie łaskami Chrystus Ukrzyżowany. Ciekawą kompozycję artystycznạ posiada figura św. Józefa dłuta mistrza T. Błotnickiego. W Domku Loretańskim znajduje się biurko ofiarowane przez Jakuba Sobieskiego w r. 1733. Klasztor posiada galerię obrazów o różnej wartości artystycznej. 
Historyczny związek z klasztorem posiada krzyż przed kościołem wzniesiony na mogile konfederatów barskich i statua N. M. Panny wznosząca się przed wojną u wylotu ul. Kapucyńskiej a przeniesiona w czasie okupacji hitlerowskiej na Planty (naprzeciw ul. Jagiellońskiej).

Pod względem administracyjnym klasztor krakowski najdłużej z obecnych konwentów prowincji krakowskiej wchodził w skład prowincji polskiej. Prowincjałowie prowincji galicyjskiej starali się o przyłączenie klasztoru krakowskiego do swojej prowincji. Zamierzali bowiem zwiększyć u siebie liczbę zakonnków a w Krakowie otworzyć klerykat. Starania te doprowadziły do wydania dekretów pozytywnych w r. 1847 i 1852, które jednak nie zostały wykonane. Dopiero w r. 1865 klasztor krakowski został formalnie przyłączony do prowincji galicyjskiej. Życie klasztorne ożywiło się z chwilą przeniesienia tu klerykatu w r. 1872. W r. 1921 dotychczasowa prowincja galicyjska została przemianowana na prowincję krakowską a Kraków został wyznaczony na stałą siedzibę prowincjała. Tu również erygowano studium filozoficzno-teologiczne. Od tej chwili rozpoczął się wzmożony rozwój życia zakonnego zahamowany dopiero wybuchem drugiej wojny światowej.

Klasztor opromienili swym życiem zakonnicy zmarli in odore sanctitatis: o. Wojciech Gedroyć, o. Wacław Nowakowski, o. Leander Lendzian, br. Stefan Rembiszewski, o. Marian Najdecki, o. Anioł Madejewski i o. Kosma Lenczowski.

Z klasztorem zrosła się legenda o insygniach królewskich. O. Wacław Nowakowski, powstaniec z 1863 r., sybirak, pisarz i pedagog wywarł poważny wpływ na patriotyczne i duchowe życie miasta i całego zaboru austriackiego.

Klasztor był znanym ośrodkiem patriotyzmu. Z jego murów wyszli kapelani konfederacji barskiej, “insurekcji kościuszkowskiej, legionów polskich i powstania warszawskiego.

Na wspomnienie zasługuje również działalność charytatywna konwentu w czasie okupacji hitlerowskiej. Z racji swej postawy patriotycznej konwent był prześladowany przez okupanta.

\section{Historia archiwum}

Najstarszy znany fragment inwentarza archiwum klasztoru pochodzi $z$ lat 1801-1819. Pierwsza część inwentarza została prawdopodobnie sporządzona przez o. Tadeusza z Warszawy, drugą opracował o. Kajetan z Lautenburga. O. Tadeusz był gwardianem klasztoru w latach 17931796, 1801 -1804 i 1810 -1811 a o. Kajetan od r. 1816-1820. Do dzisiaj 
przetrwały zaledwie szczątki tak spisu jak i samẹj zawartości archiwum. Ale i na tej skromnej i szczupłej podstawie można odtworzyć schemat i zawartość dawnego układu archiwum klasztoru.

Wspomniane archiwum dzieliło się na grupy oznaczone dużymi literami alfabetu od $\mathrm{A}$ do Z. Każda grupa z kolei podzielona była na pliki numerowane od 1 wzwyż. Dokumenty w każdym pliku nosiły numer kolejny. System ten był powszechnie praktykowany w całej prowincji polskiej.

Zapis inwentarzowy podawał najpierw sygnaturę grupy i pliku, potem numer porządkowy, krótkie streszczenie dokumentu, obejmujące wystawcę i treść dokumentu, miejsce wystawienia, dzień, miesiąc oraz rok. Każdy plik obejmował oczywiście dokumenty pokrewne. Dla ilustracji podaje przykład z pierwszej karty inwentarza:
${ }_{1}$ Nrus
Plica 1 ma b Litt. A

2. Breve Innocentii XII Papae pro fundatione hujus Conv., Romae, 1 Xbris 1691.

3. Lubomirski Mareschal. Curiae Regiae donat lapideam, Cracoviae, 13 Xbris $1683^{\prime \prime}$.

$\mathrm{Z}$ wyjątkiem podanego przykładu wszystkie inne dokumenty ułożone były w porządku ściśle chronologicznym i obejmowały lata 1683-1797.

Ostatnią literę alfabetu przeznaczono na akta personalne: „Baptismalia, Testimonialia, Ordinationes Fratrum Clericorum et Laicorum". Każdy zakonnik posiadal tutaj ponumerowane dokumenty pod swoim imieniem.

Ten sposób ewidencji zespołu archiwalnego był praktyczny i pozwalał dotrzeć szybko do potrzebnych dokumentów i akt.

Archiwum klasztorne narastało od początku fundacji. Kancelaria klasztorna musiała bowiem miéc uporządkowaną registraturę, ażeby w każdej chwili wykazać się wobec władz kościelnych i świeckich prawem własności kościoła, klasztoru i ogrodu. Nieraz również trzeba było udowodnić otrzymanie bulli, breve lub legatu. Z biegiem lat ilość dokumentów i aktów zwiększała się tak, że należało sporządzić inwentarz całego zespołu dla lepszej w nim orientacji. Wiele przemawia za tym, że pierwszy spis wykonany został dopiero na przełomie XVIII i XIX w. Wtedy bowiem, tak ze względu na znaczną ilość nagromadzonych akt jak i z powodu częstej zmiany gwardianów, należało usprawnić pracę w kancelarii klasztornej.

Archiwum klasztoru krakowskiego zawdzięcza więc wiele działalności o. Tadeusza z Warszawy, znanego pisarza, tłumacza, historyka 
oraz dobrego organizatora. Na podstawie pierwszej kroniki konwentu, pisanej cześciowo w języku włoskim i w oparciu o późniejsze akta, wtedy jeszcze zachowane w całości, opracował on na nowo kronikę klasztoru od początku fundacji aż do r. 1794. W ten sposób uratował od zapomnienia najważniejszy okres dziejów konwentu i stworzył wzór prowadzenia kroniki klasztornej, który naśladowano aż do połączenia klasz.toru z prowincją galicyjską.

W następnych latach archiwum klasztornemu poświęcali więcej uwagi o. Filip z Szumowa (1835-1841) i o. Benwenuty Kaufman z Krakowa (1847-1860). Z czasów urzędowania tych gwardianów pozostały. dobrze prowadzone kroniki oraz spora ilość akt cennych dla poznania organizacji klasztoru w tych czasach. Od chwili przyłączenia konwentu do prowincji galicyjskiej zanikło w klasztorze krakowskim zainteresowanie dawniejszymi jego aktami. Klasztory bowiem tej prowincji, skrępowane ograniczeniami ",józefinizmu” i przeciążone pracą duszpasterską, całą uwagę poświęcały sprawie własnego przetrwania.

Archiwum konwentu krakowskiego stało się ponownie przedmiotem zainteresowania dopiero na początku naszego wieku, tym razem jako żodło do dziejów nie tylko własnego klasztoru i zakonu, ale również całego narodu. W latach 1910-1912 Tadeusz Kupczyński wykorzystał zasób archiwum do studium „Kraków . w powstaniu kościuszkowskim” (Kraków 1912) i opracował inwentarz archiwum dla potrzeb Akademii Umiejętności w Krakowie. Uporządkował on jednak i spisał tylko część archiwum prowincji i klasztoru oraz varia obejmujące druki ulotne związane z ogólnymi dziejami Polski. Niestety, uporządkowany przez Kupczyńskiego materiał rozproszył się ponownie w ciągu minionego półwiecza, ponieważ nie udało się odnależć jego spisu, trzeba było pracę rozpocząc od nowa.

Dziś można stwierdzić, że po trzechwiekowej prawie działalności klasztoru nie pozostało zbyt wiele śladów pisanych. Oryginalne dokumenty fundacyjne $w$ liczbie siedmiu zostały złożone w komisji zreorganizowanej hipoteki Wolnego Miasta Krakowa w dniu 18 maja 1824 r. Pozostałe dokumenty wraz z rachunkami budowy. klasztoru przedłożono hipotece 2 czerwca $1829 \mathrm{r}$. W archiwum klasztoru pozostały tylko odpisy ważniejszych dokumentów, sporządzone w r. 1831 za rządów o. Rafała z Chelmna dla potrzeb kancelarii klasztornej. Odpisy wykonane zapewne przez jednego $z$ niższych urzędników państwowych zawierają wiele błędów. Pokażną część archiwaliów, zwłaszcza personalnych, wchłonęło archiwum prowincji polskiej. Zachowane adnotacje przekazują wiadomość o przejęciu z archiwum klasztornego dokumentów. personalnych 
przez prowincjała o. Filipa Szumowskiego w r. 1821. Później tak samo postępowali innj prowincjałowie. Tylko bardzo niewielka ilość aktów personalnych zachowała się $\mathrm{z}$ tych czasów i dziś wzbogaciła dział personalny archiwum prowincji krakowskiej.

Są wyraźne dowody, że w archiwum klasztoru krakowskiego gospodarowały nieodpowiedzialne jednostki, które bądź same przekazały część zespołu archiwalnego obcym zbiorom, bądź też pozwoliły na bezkarne w nim plądrowanie. Dlatego to jedno $z$ bogatszych archiwów kapucyńskich uległo dewastacji.

W wyniku zamiany Biblioteka Jagiellońska otrzymała 9 wartościowych rękopisów, które posiadają dzis sygnatury biblioteczne 4160-4169. Przepadły oryginały prac historycznych o. Wacława Nowakowskiego, jak téz pewne grupy listów $\mathrm{z}$ jego spuścizny, $\mathrm{m}$. in. korespondencja $\mathrm{z}$ o. Rafałem Kalinowskim z Zakonu OO. Karmelitów Bosych. Korespondencję tę w liczbie 107 listów i 114 pocztówek zabrał 4 maja 1934 r. o. Benedykt karmelita bosy, wicepostulator beatyfikacji o. Rafała. Dokładnych strat archiwum z braku dawnych wykazów ustalić się nie da.

\section{Opracowanie}

Najpierw wyłączono ze wspomnianego archiwum akta i rękopisy odnoszące się do działalności prowincji galicyjskiej i krakowskiej oraz różnych klasztorów. Materiały te, nie należące do archiwum klasztoru kraknwskiego, otrzymały miejsce w spisie zasobu archiwum prowincji k.rakowskiej.

Szczątki scalonego zespołu archiwalnego świadczą o poważnym wkładzie konwentu krakowskiego w dzieje własnego zakonu, Kościoła i miasta Krakowa.

\section{Z awartość a r chiw um}

AKK 1. Dokumenty fundacyjne kościoła i konwentu. 1683-1733. Sạ to kopie dokumentów fundacyjnych wykonane w r. 1831. Rps zawiera jeszcze dwie jednostki archiwalne: AKK 10 i AKK 95. $32.5 \times 23.5 \mathrm{~cm}$, plsk., od klb. 86-116.

AKK 2. Inwentarz archiwum klasztoru oraz dokumenty odpustowe:

1. Inwentarz Archiwum OO. Kapucynów w Krakowie. (Zachowały się tylko fragmenty). 1683-1821. K. 1-7.

2. "Brevia indulgentiarum perpetuarum". [1698-1769]. K. 8-33. 
3. "Brevia indulgentiarum". [Pergaminowe. 1761-1895]. K. $34-39$.

4. "Brevia indulgentiarum". [Papierowe. 1779-1895]. K. $40-46$.

$35.9 \times 25.5 \mathrm{~cm}$, płsk., klb. 46, knlb. 4. Druków 21, dok, perg. 6 (od k. 34-39).

AKK 3. 1. "Extractum ex Libro Resolutionum Reverendissimae Definitionis Generalis". [1633-1847].

2. Formularze używane w kancelariach prowincjała i klasztorów.

$21.2 \times 16.7 \mathrm{~cm}$, pap., slb. 84 .

AKK 4. 1. "Chronologia kościelna". [Poczet papieży do r. 1846].

2. Formularze używane $w$ kancelariach prowincjała i klasztorów.

3. "Liber Novitiorum". $[1795-1847]$.

$24 \times 19.2 \mathrm{~cm}$, płsk., slb. 61, część. zniszczony.

AKK 5. "Chronologica descriptio status interni P. P. Capucinorum Provinciae Polonae. 1740-1811".

$35 \times 20.5 \mathrm{~cm}$, bez opr., slb. 21 .

AKK 6. Dokumenty prowincji polskiej. Dekrety papieskie. Pisma królewskie. Zarządzenia i listy generalskie i prowincjalskie. ZwYczaje prowincji polskiej. (Oryginały i kopie). 1749-1860.

$38 \times 22,5 \mathrm{~cm}$, bez opr., klb. 85, knlb. 1. Jeden druk.

AKK 7. Ordynacje generalskie i prowincjalskie:

1. Ordynacje generalskie z lat: 1761, 1766. K. 1-10.

2. Ordynacje prowincjalskie $\mathrm{z}$ lat: $1760,1762,1765,1766$, 1767. K. $11-57$.

$21.3 \times 17.5 \mathrm{~cm}$, sk, klb. 57 , knlb. 4 .

AKK 8. „Ordynacje prowincjalne przy oddziale Prowincji naszej Polskiej od Czeskiej, w przytomności Komisarza generalnego ułożone roku $1762^{\prime \prime}$.

$23.7 \times 18.8 \mathrm{~cm}, \mathrm{sk}, \mathrm{klb}, 14$.

W AKK znajdują się dwa egzemplarze ordynacji. Drugi egz. posiada klb. 15.

AKK 9. "Listy dwa okólne Najprzew. o. Erharda z Radkespurgu Zakonu naszego Kapucyńskiego Ministra Generalnego. Dla wygody czytających przepisane i w tej jednej książce umieszczone roku 1793. [Na końcu rękopisu wlepiony dokument:] Decretum reformationis Conventus Ryvaldensis, ex canonica visitatione ejusdem, die 28 9-bris anno Domini 1791 emanatum". $23.5 \times 19 \mathrm{~cm}$, sk., klb. 21 . 
AKK 10. „Fasciculus producit Tentamina PP. Capucinorum Introductionis et Intromissionis ad Provinciam Lithuanam in variis locis cum variis ad hoc negocium Instantis Magnatum cum aliis scriptis pro et contra". [1763-1774].

Rps oprawiony razem z AKK 1. $32.5 \times 23.5 \mathrm{~cm}$, płsk, od klb. $117-248$.

AKK 11. „3tius Annus. Visitationes canonicae in conventibus ac hospitiis universae Provinciae Polonae in duas Custodias divisae nempe primam S. Adalberti Episc. et Mart. secundam S. Stanislai Episcopi et Mart. inhoatae. Per me Ludovicum a Kitnovia Capuc. et Ministrum provincialem. 1777 A. in mense Junio". $20.3 \times 16.5 \mathrm{~cm}$, bez opr., slb. 24, knlb. 1.

AKK 12. "Zbiór ustaw ważniejszych Kapituł i Kongregacyi Jeneralskich i Prowincyalskich na Prowincyą Polską OO. Kapucynów ułożony. A od wszystkich Ojców kapitularnych w Łomży dnia 12 Września 1845 r. zgromadzonych z chęcią i zgodnie przyjęty i podpisany".

$\mathrm{Na}$ karcie tytułowej napis: „Napisano: 1. Exemplarz do Archiwnm Prowincyi, $1 \mathrm{~d}=$ do Warszawy, $1 \mathrm{~d}=$ do Krakowa, $1 \mathrm{~d}=$ do Lublina". $25 \times 19.8 \mathrm{~cm}$, pap., slb. 73.

Rps ogloszony drukiem. Zob. AKK 13.

AKK . 13. "Zbiór ustaw ważniejszych Kapituł i Kongregacyj Jeneralskich i Prowincyalskich na prowincyję Polską OO. Kapucynów ułożony, od wszystkich Ojców kapitularnych w Łomży d. 12 Września 1845 r. zgromadzonych z chęcią i zgodnie przyjęty i podpisany a przez Władzę Najwyższą Zakonu trzykroć potwierdzonych". [Kraków 1849, Druk. U.J.].

Druk $22 \times 18 \mathrm{~cm},{ }^{\prime}$ plsk., slb. 89 , snlb. 1 .

$\mathrm{Na}$ str. tyt. napis: „Ad Cellam R. P. Guardiani Conv. Cracoviensis 30 Octobris 1849 Anno".

AKK 14. Rozporządzenia władz zakonnych generalskich i prowincjalskich. Korespondencja z prowincjałami Galicji. 1836-1942:

1. Rozporządzenia generalskie. 1849-1942. K. 1-14.

2. Korespondencja prokuratora generalnego z o. Filipem Szumowskim i z nuncjuszem wiedeńskim $w$ sprawie misji georgijskiej. 1836-1837. K. 15-31.

3. Korespondencja o. Benjamina Szymańskiego z o. Filipem Szumowskim. 1845-1850. K. 32-80.

4. Korespondencja o. Cyryla a Duchny z o. Filipem Szumowskim. $1849-1850 . \mathrm{K}, 81 \multimap 107$. 
5. Korespondencja prowincjałów galicyjskich z o. Filipem Szumowskim. 1844-1851. K. 108-163. $31.5 \times 23.5 \mathrm{~cm}$, plsk., klb. 163 knlb. 7 .

AKK 15. Rozporządzenia prowincjałów prowincji galicyjskiej i prowincji krakowskiej. 1882-1942. $35.8 \times 22 \mathrm{~cm}, \mathrm{płsk}$, klb. 106, knlb. 3 .

AKK 16. Rozporządzenia Konsystorza Krakowskiego. 1821-1916:

1. Rozporządzenia i korespondencja Konsystorza Krakowskiego. 1821-1916. K. 1-68.

2. Korespondencja klasztoru $\mathrm{z}$ Konsystorzem Krakowskim. 1821-1915. K. 69-105.

$35.8 \times 24.5 \mathrm{~cm}$, płsk., klb. 105, knlb. 4.

AKK 17. Rozporządzenia władz świeckich. 1796--1882:

1. "Cyrkularze" od władz świeckich i "kurendy" od Konsystorza Krakowskiego. (Odpisy). 1796-1882. K. 1-12.

2. Korespondencja władz austriackich z klasztorem. 1801-1809. K. 13-54.

3. "Mandata Regiminis". 1810-1929. K. 55-256.

4. Korespondencja klasztoru z władzami świeckimi. 18471882. K. 257-274.

5. Prośby klasztoru o wystawienie paszportów. 1848-1859. K. $275-302$.

$36 \times 24.5 \mathrm{~cm}$, płsk., klb. 302, knlb. 7 .

AKK 18. Organizacja klasztoru. 1784-1939:

1. Wybór dyskreta. 1922--1939. K. 1-6.

2. Tabele klasztorne na kapitułę. 1909-1933. K. 7-19.

3. Skład osobowy konwentu na kapitule. 1827-1903. K. $20-28$.

4. Zaświadczenie o przynależności do zakonu. 1857. K. 29.

5. Swiadectwa zwolnienia aspirantów z zakonu. 1847-1859. K. $30-38$.

6. Zapisy profesji. 1848, K. 39-42.

7. Obediencje klasztoru krakowskiego: Obediencje kwestarskie. 1791 -1870. K. 43-90.

8. Obediencje innych klasztorów. 1784-1789. K. 91-101.

9. Akta o o. Chryzancie. 1846-1848. K. 102-108.

10. Zaświadczenia o odbylych rekolekcjach dla księży diecezjalnych. 1841-1856. K. 109-116. 
11. Prośba o pozwolenie na czytanie książek zakazanych. 1861-1863. K. 117-118.

12. Zawiadomienie o: śmierci br. Marcina Cetnera. 1917. K. $119-120$.

13. Zaświadczenie odbioru rzeczy po Ferd. Candido. 1921. K. $121-125$.

14. Świadectwa dla służby. 1848-1852. K. 126-133.

15. Prośba o przyjęcie chorej staruszki do szpitala. K. 134.

16. Palet forszpanowy. 1879. K. 135.

17. Karta ewidencyjna koni klasztornych. 1924. K. 136-137.

18. Sprawa tabaki. 1796. K. 138.

36 x 24 cm, plsk., klb. 138, knlb. 19.

AKK 19. Organizacja klasztoru. Korespondencja, Zabytki. Studia kleryków. Działalność religijna i kulturalna. 1806-1946:

1. Korespondencja gwardianów krakowskich. 1844-1924. K. 1-39.

2. Zakaz sprzedaży zabytków. 1894. K. 40-41.

3. Uznanie kościoła, Loretu i klasztoru za obiekty zabytkowe. 1932. K. 42-44.

4. Kościół wolny od rekwizycji wojskowej. Zabranie dzwonu z Loretu w r. 1917. K. 45-48.

5. Kościół i klasztor w czasie wojny 1939-1945. K. 49-52.

6. Tablica pamiątkowa ku czci T. Kościuszki na ścianie zewnętrznej Loretu. 1894. K. 53-54.

7. Grób konfederatów barskich. 1905. K. 55.

8. Figura Matki Bożej przed kościołem. 1917. K. 56.

9. Puget L.: Co się stało w niedzielę w kapucyńskim kościele. (Druk). K. 57.

10. Budowa oranżerii i kanałów. 1850, 1908. Restauracja kościoła i klasztoru. Nowa wieża. 1847-1855. K. 58-72.

11. Drzwi kościelne. 1910. K. 73-74.

12. Szafy do zakrystii. 1910. K. 75.

13. Sprawa zatwierdzenia planów budowy klasztoru. 1931. K. 76-77.

14. Poświęcenie dzwonu w Lorecie. 1946. K. 78-83.

Studia kleryków:

15. Porządek dnia. K. 84.

16. Zarządzenia dla kleryków. K. 85. 
17. Adoracja Najśw. Sakramentu. 1830-1857. K. 86-94.

18. Przemówienie na otwarcie studium filozofii w r. 1828. K. 95-98.

19. Przemówienia przed egzaminem kleryków. 1838-1842. K. 99-102.

20. Przemówienie z okazji imienin gwardiana, K. 103-106.

21. Zezwolenie na egzamin dla ks. Studentowicza kan. reg. 1846. K. 107.

22. Pozwolenie prowincjała na przyjęcie święceń. 1848. K. 108.

23. Pozwolenie na egzamin jurysdykcyjny. 1848-1856. K. $109-114$.

Działalność religijna i kulturalna:

24. Zaświadczenie o przysposobieniu religijnym. 1848. K. $115-116$.

25. Prośba o chrzest. Metryki chrztu św. 1845-1848. K. 117 124.

26. Śluby. 1869, K. 125.

27. Pogrzeby. 1806-1852. K. 126-130.

28. Sprawa wydania modlitewnika "U stóp Marii". 1905. K. 131.

29. Sprawa wydania "Nowego Brewiarzyka Tercjarskiego" w Królestwie Polskim. 1907. K. 132-133.

30. Łaska otrzymana za pośrednictwem M. B. Loretańskiej. 1925. K. 134.

31. Dyplom "Caritasu” dla klasztoru. 1934. K. 135.

32. Biblioteka OO. Kapucynów w Krakowie. 1931. K .136-138.

33. Odczyt o. Laureana przez radio (Katowice). 1932. K. 139143.

36.4 x 24 cm, płsk., klb. 143, knlb. 34 .

AKK 20. "Książka meldunkowa. Nr domu 11. Ulica Loretańska. Nazwisko właściciela domu: Klasztor OO. Kapucynów“. [Zameldowano 332 osoby. 1913-1931].

$23 \times 14.8 \mathrm{~cm}$, płpł., klb. zapis. 38 .

AKK 21. „Felices Patres ac Fratres Peregrini fundatoribus Benefactoribusque permixti migrantes e corpore recesserunt. Patriam tendentes caelestem peregrinis a vivis pia suffragia poscentes ab anro peregrinationis 1691 Polono Peregrino Almae Custodiae Polonae consignante A. D. 1750". [Mortuologium zawie- 
rające wykaz zmarłych zakonników, fundatorów i dobroriziejów Zakonu OO. Kapucynów w Polsce. 1691-1790]. $31.8 \times 19.5 \mathrm{~cm}$, płsk., klb. $\mathbf{5 3}$, zapis. 47.

AKK 22. ,Mortuologium seu Calendarium Patrum et Fratrum Ordinis Minorum S.P.N. Francisci Capucinorum in Provincia Po'ona mortuorum ex mandato A.R.P. Stanislai a Markuszovia Ministri Provincialis conscriptum. Anno Domini 1791. Pro Conventu Cracoviensi. Hic liber restauratus est de novo, et prima vice introducti et inscripti Benefactores hujus Loci per R. P. Berardum a Czarnocin sub Guardianatu R. P. Cajetani a Lautenburg Anno Domini 1816. Mense 7bri". $21.5 \times 18 \mathrm{~cm}$, sk., slb. 445 .

AKK 23. "Mortuologium seu Cathalogus Patrum et Fratrum nostrorum Ordinis Minorum S.P.N. Francisci Capucinorum in Provincia Polona mortuorum nec non defunctorum fundatorum convenwum $€$ jusdem Provinciae et singularium Benefactorum hujus nostri Cracoviensis Conventus secundum ordinem mensium ei dierum in quibus obierunt, collectus et conscriptus. Pro sacristia hujus nostri Conventus et Ecclesiae Cracoviensis. Ut sacerdotes nostri quotidie accedentes ad Sacrum Altare meminerint in Sacrificiis Missae horum, qui qualibet die adnotantur Fratrum, Benefactorum, Fundatorum nostrorum. Freчuenterque suspirent ad Deum cum Ecclesia: Pie Jesu Domine, dona eis requiem sempiternam. Conscriptus et ordinatus noviter Cathalogus iste per Fr. Thadaeum a Varsavia Capucinum. Anno post Christum Natum: 1804". [1692-1846]. $32 \times 19.5 \mathrm{~cm}$, płsk., slb. 94 .

AKK 24. ,Cathalogus Patrum et Fratrum Capucinorum Provinciae Polonae' . [1718-1768]. $21.5 \times 17.2 \mathrm{~cm}$, pap., klb, 19, k. 14 i 15 niezapis.

AKK 25. "Caihalogus PP. et FF. Capucinorum Provinciae Poloniae Anno Domini 1766 conscriptus". [1718-1771].

Na karcie tutułowej napis: „R, Patri Severino Lubartoviensi”. $20.2 \times 14 \mathrm{~cm}$, bez opr., klb. 18 , knlb. 2 .

AKK 26. .Cathalogus PP. et FF. Ordinis Minorum S.P.F. Capucinorum Frovinciae Poloniae SS. Adalberti et Stanislai Episcoposum Marlyrum". [1770-1848].

$20 \times 16 \mathrm{~cm}$, bez opr., klb. 14, k. 9 niezapis.

AKK 27. ".ratres in Provincia Poloniae defuncti". [1687-1782].

Druk, 16.2 x $9.8 \mathrm{~cm}$, pap., knlb. 8. (4 egzempl.). 
AKK 28. "Fratres nostri defuncti". [Tytuł okładziny przedniej. 16871798]. „Parentes Fratrum nostrorum defuncti ad M. Dei Gloriam. Ubi etiam adnotati Fundatores Benefactoresque ac qui sunt sepulti in Cripta Ecclesiae Nostrae Conventus Vinnicensis". [Tytul okładziny tylnej. 1696-1799].

19.8 × $16 \mathrm{~cm}$, płsk., klb. 9. k. 9 niezapis., klb. 11.

AKK 29. "Defuncti Patres et Fratres nostri a Coniunctione utriusque Galliciae Anno 1806 ad hunc annum 1809 inclusive". $17.2 \times 10.8 \mathrm{~cm}$, bez opr., klb. 2.

AKK 30. "Cathalogus PP, et FFr. Provinciae Polonae Capucinorum". Zawiera odpisy rę̧kopisów: AKK 24, 27, 25, 26 i 28. $30 \times 21 \mathrm{~cm}, \mathrm{pl}$., slb. 118, knlb. 1 .

AKK 31. Wykład reguły dla nowicjuszy Zakonu OO. Kapucynów. Pocz. XIX w.

Rps bez początku i końca.

$20.2 \times 16.3 \mathrm{~cm}$, bez opr., klb, 12 .

AKK 32. „Początki życia zakonnego dla nowicyuszów i młodych professow Zakonu S. O. Franciszka Kapucynów... Nayprzód we Lwowie R. 1773 teraz powtórnie z rozkazu Zwierzchności do druku podane. [Warszawa 1787, Druk. F. Dufour].

Druk, $16.3 \times 9.7 \mathrm{~cm}$, płsk., slb. 154, knlb. 2.

Na pierwszej karcie ochronnej napis: „Fr. Bernardo a Cracovia Cler, Prof. Ord. S.P.F. Capucinorum donavit F. Victor Cler. Capucin, pro memoria".

AKK 33. "Cathalogus Fratrum Novitiorum Clericorum et Laicorum Capucinorum Conventus Cracoviensis Anno 1817 in Augusto inchoatus, post Congregationem Łomżae eodem anno 20 Junii celebratam per Fratrem Berardum pro tunc Vicarium Lectorem ac Magistrum, sub Provincialatu A.R.P. Viatoris a Bessovia et Guardianatu R.P. Cajetani a Lautemberg conscriptus. $\mathrm{Ab}$ anno medio Magisteriam accepit ex decisione Superiorum R. P. Agrippinus Goleszoviensis". [1817-1821]. $22.2 \times 17.5 \mathrm{~cm}$, płsk., klb. 63 .

AKK 34. "Liber Novitiorum O.S.P. Francisci Capucinorum in Conventu Cracoviensi ab anno 1834". [1834-1864].

$32.5 \times 20 \mathrm{~cm}$, płsk., klb. 82 , zapis. 45 .

AKK 35. ,Conclusiones, propositiones ex universa Theologia vel Philosophia". [Tezy studiów domowych Zakonu OO. Kapucynów i innych zakonów w liczbie 33 rękopisów i druków. 17491803].

Druki, $23 \times 17.5$ i mniej, 33 jedn. arch. 
AKK 36. „Conclusiones, propositiones ex universa Theologia vel Philosophia". [Tezaria roczne, tematy dysput, w większości dotyczące studiów domowych Zakonu OO. Kapucynów w Krakowie, Lublinie, Warszawie oraz innych zakonów względnie seminariów diecezjalnych. Zawiera 33 tezaria, w tym dwa druki. 1776-1900].

31 , druki 2, $25.5 \times 40 \mathrm{~cm}$, i mniej, bez opr.

AKK 37. „Inventarium Ecclesiae et Conventus nostri Capucinorum Cracoviensium. Sub Guardianatu R. P. Thadaei a Varsavia pro tunc Definitoris et custodis descriptum. Anno Domini 1794. Diebus mensis Julii".

$19.5 \times 16.5 \mathrm{~cm}$, płsk., k1b. 28, zapis. 23 .

AKK 38. "Inwentarz sprzętów kościelnych i klasztornych Xięży Kapucynów Krakowskich z wyszczególnieniem, co przybyło lub ubyło, spisany z polecennia Przewielebnego Ojca Benjamina Prowincyała pod Gwardyanią Ojca Filipa. - Podany w drugim Exemplarzu na Kapitułę Nowomiejską dnia 20 września 1839 roku". [1839-1842]. $33 \times 21 \mathrm{~cm}$, płsk., klb., 44, zapis. 13.

AKK 39. Inwentarze kościoła i klasztoru OO. Kapucynów w Krakowie. Od r. 1798-1936.

Jedenaście inwentarzy razem oprawionych.

39 x $25.3 \mathrm{~cm}$, płsk., klb. 187, knlb. 3 .

AKK 40. „Inwentarz klasztoru OO. Kapucynów w Krakowie, sporządzony wskutek rozporządzenịa Wysokiego C. K. Namiestnictwa we Lwowie z dnia 6 lutego 1870. L. 2070, za staraniem ówczesnego Gwardiana Ks. Wiktora Klimek, definitora I Zakonu OO. Kapucynów Prowincji Galicyjskiej. Kraków dnia 12 kwietnia $1875^{\prime \prime}$.

$40 \times 25.5 \mathrm{~cm}$, płpł., slb. 424 .

AKK 41. „Akt darowizny kielicha przez Kazimierza Małeckiego do kościoła OO. Kapucynów z zastrzeżeniem, ażeby go używano przy odprawianiu Mszy św. odprawianej za spokój duszy Teodory z Korolewiczów Małeckiej. 1932".

Akt $\mathrm{z}$ fotografia kielicha w oprawie płpł. o wymiarach $35.5 \times 23 \mathrm{~cm}$.

AKK 42. "Conversi ad fidem in Ecclesia nostra. Extractus de libro Historiae Conventus Cracoviensis O.N.S. P. Francisci Capucinorum conversorum ad fidem catholicam a patribus nostris ab initio fundationis ejusdem ut facilius inveniri possint in casu necessitatis, Factus cura et solicitudine R. P. Augustini a Mar- 
cusovia Definitoris Provinciae et Actualis Guardiani A. D. 1789 diebus Februarii". [Tytuł na okładzinie przedniej. 17391837]. „Baptisati in Ecclesia nostra. Extractus Baptisatorum in Ecclesia nostra Cracoviensi Capucinica in Anno 1789 diebus Martii factus". [Tytuł na okładzinie tylnej. 1728-1852]. $30.3 \times 19.3 \mathrm{~cm}$, plsk., klb. 9. zapis. 7. klb. 9 .

AKK 43. "Qui contraxerunt matrimonium in Domo Lauretana vel in Ecclesia nostra. Extractus de Libro Historiae Conventus Cracoviensis eorum qui in Ecclesia nostra sive in Domo Lauretana contraxerunt matrimonium. Factus cura et solicitudine R. P. Augustini a Marcusovia Definitoris Provinciae et actualis Guardiani. A. D. 1789. Diebus Martii". [1710-1891]. $34.5 \times 21.2 \mathrm{~cm}$, płsk., klb. 16 , zapis, 14 .

AKK · 44. "Księga ślubów. Kościół OO. Kapucynów w Krakowie". [1913-1948]. $33.5 \times 21 \mathrm{~cm}$, płpł., slb. 102 .

AKK 45. "Księga chorych, zaopatrywanych przez OO. Kapucynów w domach". [1913-1946]. $33.5 \times 21 \mathrm{~cm}$, płpł., slb. 101 .

A.KK 46. „Sepulti Fratres nostri. Extractus de libro Historiae Conventus Cracoviensis O. S. P. Francisci Capucinorum. Quinam quo anno et die obierunt in Domino nostri Patres et Fratres ut facilius inveniri possint in casu necessitatis. Factus cura et solicitudine R. P. Augustini a Marcusovia Definitoris Provinciae et actualis Guardiani A. D. 1789. Diebus Decembris". [Tytuł na okładzinie przedniej. 1711-1842]. "Sepulti in Ecclesia nostra saeculares. Fundatores et Benefactores nostri sunt sepul$t i$ in Ecclesia et cemeterio ab initio fundationis nostri Conventus et Ecclesiae Cracoviensis O. S. P. Fr. Capucinorum". [Tytuł na okładzinie tylnej. 1716-1860]. $34.6 \times 21.5 \mathrm{~cm}$, płsk., slb. 6 , slb. 11 .

AKK 47. "Księga chorych, ślubów, pogrzebów i celebr obcych księży w kościele OO. Kapucynów w Krakowie". [Do użytku zakrystii. 1892-1912].

$29 \times 22.5 \mathrm{~cm}$, płsk., slb. 243 .

AKK 48. "Księga celebr obcych księży w kościele OO. Kapucynów w Krakowie od r. 1911-1951".

$33.5 \times 21 \mathrm{~cm}, \mathrm{płpł}$., slb. 88 .

AKK 49. "Szkaplerz czyli Opieka św. Józefa, Oblubieńca Najśw. Maryi od r. 1894-1904". [Księga wpisowa do Bractwa św. Józefa]. $39.2 \times 12,5 \mathrm{~cm}$, pł., slb, 180 , 
AKK 50. "Registrum omnium librorum Bibliothecae, Cracoviensis Conventus PP. Capucinorum. Anno Domini MDCCXXX die XXII novembris". $32.4 \times 20.5 \mathrm{~cm}$, sk., klb. 58, częśc. uszkodz.

AKK 51. "Elenchus librorum Bibliothecae Cracoviensis P. P. Capucinorum 1769 anno conscriptus" [1769-1790].

$33.9 \times 21.7 \mathrm{~cm}$, sk., klb. 55 .

AKK 52. „Catalogus librorum Bibliothecae PP. Capucinorum Conventus Cracoviensis. Cura et Solicitudine A. V. P. Pontiani Vizunensis guardiani opera et studio A. V. P. Joannis Chrysostomi Varsaviensis vicarii adjutorio et manu PP. Martini et Eustachii studentium philosophiae. Labore sex mensium et ultra in ordinem redactae. Concinnatus digestus ac conscriptus anno 1790 diebus aestivis". $36.8 \times 24.5 \mathrm{~cm}$, sk., klb. 84, zapis. 80 . Oprawa uszkodz.

AKK 53. "Katalog Biblioteki OO. Kapucynów w Krakowie". [XIX i XX w. .".

$39.2 \times 24.5 \mathrm{~cm}, \mathrm{pł}$, slb. 410 . Rps uszkodz.

AKK 54. „Księga wypożyczanych książek w Bibliotece OO. Kapucynów w Krakowie". [1893-1911].

$37.9 \times 24.2 \mathrm{~cm}$, pap., slb. 84, zapis. 56 .

AKK 55, Archiwum redakcji czasop. „Pokój i Dobro”. 1936-1939. Kraków ul. Loretańska 11. Red. o. Alojzy Wojnar:

"Teczka 1. Artykuły dane do aprobaty duchownej". Slb. 199. "Teczka 2. Zbiór rachunków administr. "Pokój i Dobro", Slb. 178.

"Teczka 3. Kongregacje III Zakonu św. Franciszka OO. Kap. Prow. Krak. i red. korespondencja w różnych sprawach". Klb. 105.

„Teczka 4. Maszynopisy pracy "Dobrobyt" ks. Leona Zaziemskiego".

"Teczka 5. Spis adresów prenumeratorów".

$36 \times 25 \mathrm{~cm}$, pap., str. i k. jw.

AKK 56. Archiwum redakcji czasop. „Pokój i Dobro”. Kraków, ul. Loretańska 11. Red. o. Alojzy Wojnar:

„Teczka 1. Biografie - Historia. Slb. 53.

„Teczka 2. Tematy franciszkańskie. III Zakon." Slb. 94.

"Teczka 3. Życie duchowne - ascetyka". Slb. 107.

"Teczka 4. Apologetyka - katechizm". Slb. 22. 
"Teczka 5. Felietony - pogadanki". Slb. 82.

"Teczka 9. Poezje". Slb. 159.

"Teczka 10. Rozmaitości". Slb. 12.

$35 \times 25 \mathrm{~cm}$, pap., str, i k. jw.

AKK 57. Sprawy majątkowe. 1800-1930.

1. Hipoteka. 1880-1930. K. 1-7.

2. Obligacje. 1841-1891. K. 8-16.

3. Pożyczki z funduszów klasztoru. 1800-1868. K. 17.-22.

4. Sprawa zapisu 70 korcy zboża na Młynówce. 1909. K. 23-29.

5. Proces z księciem Jabłonowskim. 1874-1878. K. 30-40.

6. Sprawa ogrodu przy ul. Studenckiej. 1907. K. 41-45.

7. Podatki. $1802-1899$. K. 46-116.

8. Kwity. 1808-1899. K. 117-157.

9. Kwity bankowe. 1897-1919. K. 157-178.

35.7 x $24.5 \mathrm{~cm}$, płsk., klb. 178, knlb. 10.

AKK 58. "Allmossen Cassa Buch". [Tytuł okładziny przedniej. 17721802]. "Fabriquaen Cassa Buch". [Tytuł okładziny tylnej. 1772--1787].

$35.2 \times 21.5 \mathrm{~cm}$, sk., klb. 72, zapis. 57, klb. 18.

AKK 59. „Percepta eleemosynae Conventus. Regestr percepty Konwentu Krakowskiego od dnia 1 czerwca roku 1787 za czasów W. O. Gward. Augustina“. [Tytuł okładziny przedniej. 17871814]. „Expensa Conventus. Regestr expensy Konwentu Krakowskiego od dnia 1 czerwca r. 1787 za czasów W. O. Gwardiana Augustyna“. [Tytuł okładziny tylnej. 1787-1814]. $32.5 \times 20 \mathrm{~cm}$, płsk., klb. 31, klb. 73, zapis. 71 .

AKK 60. „Liber perceptarum". [1845-1888].

$31.5 \times 13 \mathrm{~cm}$, płsk., klb. 175, zapis. 121 .

AKK 61. "Liber expensarum". [1845-1872].

$31.5 \times 13 \mathrm{~cm}$, płsk., klb. 172.

AKK 62. „Rejestr wydatków od 1872 do 1888”.

$41 \times 13 \mathrm{~cm}$, płpł., klb. 173, zapis. 140.

AKK 63. „Księga dochodów i rozchodów od r. 1872 do 1879". $24.8 \times 19.5 \mathrm{~cm}$, plsk., slb. 169.

AKK 64. „Księga dochodów". [1883-1901]. $39.2 \times 13 \mathrm{~cm}, \mathrm{płpł}$, slb. 100 .

AKK 65. „Księga przychodów i rozchodów”. [1891-1895]. $20.6 \times 17 \mathrm{~cm}$, płpł., klb. 95 . 
AKK 66. „Księga kasowa“. [1896-1897]. $39 \times 12,5 \mathrm{~cm}$, płpł., slb. 44 . Rps uszkodz.

AKK 67. „Księga kasowa”. [1906--1916]. $33.5 \times 21 \mathrm{~cm}, \mathrm{pt.}, \mathrm{slb} .300$.

AKK 68. "Księga kasowa“. [1917-1923]. $33.5 \times 21.5 \mathrm{~cm}$, płpł., slb. 192 , zapis. 174 .

AKK 69. „Książka dochodów i rozchodów". [1923-1936]. $33.2 \times 20.5 \mathrm{~cm}, \mathrm{p \nmid pl}, \mathrm{klb} .194$.

AKK 70. „Msza' Polska i Ave Maria - Bolesława Wallek Walewskiego. Rozliczenie kasowe z rozsprzedaży". [1936-1937]. $33 \times 21 \mathrm{~cm}$, pap., klb. 38 .

AKK 71. „Wydatki z czasów okupacji hitlerowskiej oraz rozmieszczenie $w$ celach klasztornych wysiedlonych $z$ Poznania i $z$ innych miejscowości. Spisane przez br. Efrema". [1940-1948]. $12.8 \times 8 \mathrm{~cm}$, pł., slb. 190 .

AKK 72. „Inscripto Missarum. Die 1 Septembris 1856 A. D.": [18561885]. $32 \times 12 \mathrm{~cm}$, plsk., klb 159 , zapis. 127 .

AKK 73. „Księga mszalna”. [1886-1897]. $29 \times 12 \mathrm{~cm}, \mathrm{pl}$., klb. 102 , zapis. 100 .

AKK 74. „Księga mszalna”. [1893-1896]. $22.2 \times 14 \mathrm{~cm}$, płpł., klb., 45 .

AKK 75. „Księga mszalna”. [1909-1915]. $39.2 \times 24.5 \mathrm{~cm}, \mathrm{p} ł ., \mathrm{slb} .524$.

AKK 76. „Księga mszalna". [1912-1915]. $39.2 \times 24.5 \mathrm{~cm}, \mathrm{pł}$., slb. 492 .

AKK 77. „Księga mszalna“. [1915-1917]. $25.5 \times 21 \mathrm{~cm}$, płpł., slb. 120 .

A.KK 78. "Księga mszalna". [1917-1920]. $39 \times 24.5 \mathrm{~cm}$, pł., slb. 478 .

AKK 79. „Zapis odprawianych Mszy św. przez o. Bernarda kapucyna w Krakowie od roku 1882 dnia 19.I." [do dnia 14 kwietnia 1896]. Klb. 1--85. "Wykaz kazań i nauk głoszonych przez Ks. Bernarda kapucyna z Krakowa od r. 1882" [do 1896 r.]. Klb. $89-100$. $32.5 \times 12.7 \mathrm{~cm}, \mathrm{pl}$, klb. 100 .

AKK 80. "Celebrationes Missarum Fr. Thomae de Górski Rymanoviensis Capucini. Junius 1885-1891". [Zawiera także wykaz innych prac duchownych jak: ilość wyspowiadanych osób, kazania, chrzty, śluby].

$16.3 \times 10 \mathrm{~cm}$, płpl, slb. 156, knlb, 48, 
AKK 81. Legaty. Testamenty. 1798-1935. $36 \times 23 \mathrm{~cm}$, płsk., klb. 481, knlb. 3 .

AKK 82. Legaty mszalne. 1844-1904. $33 \times 21 \mathrm{~cm}$, plsk., slb. 113.

AKK 83. „Księga legatowa OO. Kapucynów Krakowskich". [Kopia. 1861-1921]. $39.5 \times 24.5 \mathrm{~cm}, \mathrm{plpl}$, slb. 200.

AKK 84. „Księga legatowa A. Wykaz papierów wart. zawinklowanych na rzecz fundacyi mszalnych przy kościele OO. Kapucynów w Krakowie". [1904-1918]. $24.5 \times 19.8 \mathrm{~cm}$, pl., slb. 400 (większość niezapis.).

A.KK 85. „Księga legatowa B. Wykaz papierów wartościowych niewinkulowanych legatowych, stanowiących fundusz żelazny łącznie z książeczkami kas oszczędnościowych a) miasta Krakowa, b) kasy powiat. krak., jakoteż losów, wymienionych wewnątrz, będących pod wyłącznym zarządem i administracyą oo. Kapucynów krakowskiego konwentu. Zawiera również wykaz książeczek kas oszczęd. na msze św. gregoryańskie mające się odprawić po śmierci tych osób, które je złożyły. Zawiera również wykaz książeczek i papiẹrów w depozycie będących". [1904-1921].

$21 \times 16.5 \mathrm{~cm}$, płsk., slb. 400 (większość niezapis.).

AKK 86. "Fundacyjne msze św. 1921-1930". $24.7 \times 20 \mathrm{~cm}$, płpl., slb. 336 (większość niezapis.).

AKK 87. Plany klasztoru i kościoła. 1907-1944.

Plany, 33 x $24.5 \mathrm{~cm}$, płpł., pl. 78, knlb. 19.

AKK 88. „Projekt powiększenia kościoła oo. Kapucynów w Krakowie. Skala $1: 100$. Projekt. inż. arch. dypl. Antoni Ippoldt. [1937]. Plany opr., $34 \times 21 \mathrm{~cm}$, pl., pl. 8, knlb. 3.

AKK 89. Kwity. Cz. I. 1909-1931. $36.3 \times 25 \mathrm{~cm}$, płsk., klb. 520, knlb. 42 .

A.KK 90. Kwity. Cz. II. 1932-1941. $36.3 \times 25 \mathrm{~cm}$, płsk., klb. 52.1-1104, knlb. 60.

AKK 91. Księga aktów konwentu krakowskiego OO. Kapucynów od ro$\mathrm{ku} 1910$.

$42.5 \times 25.5 \mathrm{~cm}$, płsk., slb. zapis. 157 .

AKK 92. "Protoḱłól czynności. 1909-1933".

$41 \times 26.2 \mathrm{~cm}$, płpł., slb. 284 , zapis. 39 .

AKK 93. „Protokół. 1933".

$33.7 \times 20.5 \mathrm{~cm}$, płpł., klb. 100 , zapis. 23. 
AKK 94. „Krótki spis życia, cnót i czynów niektórych Kapłanów i Braci Zakonu Swiętego Franciszka Braci Mniejszych Kapucynów Prowincyi Polskiej". [1692-1810]. $39.5 \times 23.5 \mathrm{~cm}$, bez opr., slb. 59 .

AKK 95. Kronika klasztoru OO. Kąpucynów w Krakowie. 1728-1794. (W jęz. włoskim i łac.).

Oprawiona razem z AKK 1.

$32.5 \times 23.5 \mathrm{~cm}$, płsk., klb. $1-85$.

AKK 96. "Historia Conventus Nostri Capucinorum Cracoviensium". [1687-1836].

Kromika opracowana przez o. Tadeusza w r. 1794 na podstawie rękopisu AKK 95 oraz innych źródeł.

$36 \times 21.5 \mathrm{~cm}$, sk., slb. 504, knlb. 12, slb. 24.

AKK 97. "Historia Conventus Nostri Capucinorum Cracoviensium". [Odpis kroniki AKK 96 wykonany w r. 1950].

$29.7 \times 21 \mathrm{~cm}$, płsk., slb. 522, slb. 5, slb. 13.

AKK 98. "Continuatur Historia Conventus Cracoviensis Patrum Capucinorum in Arno 1836. Tomus secundus. 1836-1894".

$35 \times 21.5 \mathrm{~cm}, \mathrm{p} \nmid \mathrm{sk} ., \mathrm{slb} .360$.

$\therefore K K$ 99. „Kronika klasztoru oo. Kapucynów w Krakowie. Pisana przez Ks. Józefa Maryę z Warszawy kustosza generalnego i wikarego konwentu. [Tom III]. 1894-1906".

$35 \times 21.5 \mathrm{~cm}$, plsk., slb. 346 .

AKK 100. „Kronika klasztoru oo. Kapucynów w Krakowie" [Tom IV. 1906-1959].

$34 \times 21 \mathrm{~cm}, \mathrm{pl}, \mathrm{slb} .492$.

AKK 101. „Kronika klasztoru oo. Kapucynów w Krakowie. [Tom IVa]. $1940-1954$.

$29.8 \times 25 \mathrm{~cm}, \mathrm{płpl}$, slb. 96 .

3. Zawartość archiwum

AKL 1. "Inventarium Leopoliense". [XVIII w.].

$33.2 \times 21 \mathrm{~cm}$, bez opr., klb. 6 , knlb. 2 .

AKL 2. "Processus Loci Ordinarii et Circularia Officii Circularis a die 22 Julii 1782 a. sub regimine P. Alexandri Guard. et Commissarii Prov." [1782-1803].

$32 \times 19.8 \mathrm{~cm}$, płsk., klb. 67 .

AKL 3. Historia Conventus Leopoliensis. 1707-1781.

$34.5 \times 21 \mathrm{~cm}$, sk., slb. 130 . 


\section{ARCHIWUM KLASZTORU W SEZDZISZOWIE}

\section{Historia klasztoru}

W r. 1738 Michał Potocki wojewoda wołyński postanowił ufundować w swoich dobrach w Sędziszowie klasztor kapucynów, ażeby „przez to continuos mieć przed Panem Bogiem exoratores". Zwrócił się z prośbą do biskupa krakowskiego kardynała Lipskiego o wyrażenie zgody na budowę klasztoru. Kardynał zarządził rewizje miejsca wyznaczonego pod fundację. Równocześnie o. Liboriusz komisarz generalny zakonu zwrócił się do przełożonych sąsiednich klasztorów, ażeby poparli nową fundację. Pod warunkiem otrzymania pozytywnych opinii kard. Lipski zgodził się 18 lutego 1739 r. na erekcję klasztoru w Sędziszowie. Zgodę swoją uzależnił jedriocześnie od dotrzymania umowy zawartej między miejscowym prepozytem ks. Karolem Orłowskim a Michałem Potockim. Umowa ta dotyczyła zamiany gruntu $\mathrm{z}$ beneficjum parafialnego, który najbardziej nadawał się pod budowę. Za 130 zagonów z tegoż beneficjum Potocki zobowiązał się oddać 170 zagonów swojego gruntu a za 64 zagony tyleż ziemi szpitalowi ubogich. Ponadto kościół parafialny otrzymał jeszcze 30 zagonów tytukem rekompensaty za stratę dziesięcin wynikłą z budowy klasztoru. Grunt pod budowę od dawna "Pachnowszczyzna" zwany oznaczono dwoma krzyżami.

Po pokonaniu wszystkich wstępnych trudności, Kongregacja dla Biskupów i Zakonników wydała w dniu 18 września 1739 r: dekret zezwalający na budowę klasztoru w Sędziszowie.

Budowę rozpoczął architekt Jan Opitz, którego o. Liboriusz przyjął do Kościola Katolickiego w r. 1738 we Lwowie. Kamień węgielny pod budowę poświęcił i położył, na mocy władzy udzielonej mu przez kard. Lispkiego, dnia 26 października $1741 \mathrm{r}$. proboszcz z Trzciany ks. Józef O]szewski. Budowa trwała długo. Dopiero w r. 1756 prepozyt sędziszowski ks. Jan Krasnosielski poświęcił nowy kościół i przeniósł Najświętszy Sakrament z drewnianej kaplicy do murowanego kościoła pod wezwaniem sw. Antoniego.

W wielkim ołtarzu umieszczono obraz patrona kościoła św. Antoniego. Od strony Lekcji rozmieszczono trzy ołtarze: św. Kajetana, M. B. Częstochowskiej i św. Feliksa. Od strony Ewangelii wzniesiono także trzy ołtarze: św. Jana Nepomucena, Chrystusa Ukrzyżowanego i św. Franciszka. Obraz M. B. Częstochowskiej jest darem fundatora. Ma wielką wartość historyczną. Był bowiem obozowym obrazem wojsk polskich i zaw- 
sze słynął licznymi łaskami. Pierwsi zakonnicy sędziszowscy, Czesi z pochodzenia, szerzyli w całej okolicy kult sw. Jana Nepomucena, którego posąg ustawiono przed klasztorem. Wkrótce figury świętego pojawiły się w szerokim zasięgu działalności klasztoru. Po wykończeniu wnętrza odbyła się konsekracja kościoła i ołtarzy, której dokonał dnia 28 września 1766 r. bp sufragan przemyski Ignacy Krzyżanowski.

Pierwotny klasztor pozostał w stanie niezmienionym aż do r. 1930, w którym to o. gwardian Roman Bałul nadbudował drugie piętro od strony południowej i wschodniej. Piętro to zostało przeznaczone na nowicjat.

Życie klasztorne rozwijało się dobrze. Zakonnicy spełniali z gorliwością swoje posłannictwo. Dopiero okres józefinizmu zaciążył niekorzystnie na życiu klasztoru. Sędziszowski konwent figurował na liście kasacyjnej. Dlatego starosta rzeszowski Riedheim stale szantażował zakonników groźbą kasaty. Zastraszeni kapucyni godzili się więc na wszystko, byle uniknąć większego zła. Tak więc rozebrano mur okalający klasztor rzekomo na budowę kwater dla wojska. Zniszczono studnię klasztorną. Bogatą i cenną bibliotekę skasowano, przewieziono do Rzeszowa i oddano na pastwę urzędników.W salach bibliotecznych i w części klasztoru zakwaterowano żołnierzy wraz $\mathrm{z}$ ich rodzinami. Całymi latami nieremontowany klasztor niszczał coraz bardziej. Podobne były losy klasztoru w czasie pierwszej i drugiej wojny światowej.

W murach klasztoru przebywało wielu świątobliwych zakonników. Tu zmarł w r. 1861 o. Stanisław Krzysik znany ze świętości życia. Tu również najczęściej przebywał o. Zenon Gorlicki, asceta i historyk, zmarły w r. 1936. O. Florian Janocha propagował niestrudzenie III Zakon. O. Edward Zelek w czasie pierwszej wojny świalowej starał się u władz rosyjskich i austriackich o aprowizację dia całego miasta. O. Marian Najdecki, gwardian i magister nowicjuszy, dawał wszystkim żywy wzór chrześcijańskiej doskonałości.

Klasztor na przestrzeni dwóch wieków był bardzo aktywnym ośrodkiem działalności duszpasterskiej i wychowawczej. Tutejsi zakonnicy w czasie morowego powietrza w r. 1846 i 1855 oddawali wiernym posługi duchowne.

Klasztor sędziszowski był ulubioną siedzibą prowincjałów galicyjskich. Tutaj wreszcie od dawnych czasów znajdował się nowicjat, w którym kształtowały się charaktery młodego narybku zakonnego. Tę funkcję spełnia klasztor do dzisiaj. 
2. Historia archiwum

Najstarsze dokumenty fundacyjne noszą sygnaturę "H: h:" łącznie z numeracją liczbową. Napis na odwrocie "Documenta Conv. Sędziszov": wskazywałby na istnienie tu uporządkowanego archiwum klasztornego. Są to jednak z całą pewnością znaki archiwum prowincji polskiej, zwłaszcza, że nie wszystkie dokumenty fundacyjne mają powyższe sygnatury. Część dokumentów posiada na odwrocie treść dokumentu bez żadnych sygnatur. Te ostatnie $\mathrm{z}$ pewnością były $\mathrm{w}$ posiadaniu konwentu. Grupa dokumentów z sygnaturami została przekazana urzędowo po podziale prowincji polskiej.

Inwentarz klasztoru z r. 1827 wylicza cztery dokumenty, które były w posiadaniu archiwum a mianowicie: oryginał dokumentu zezwalającego na konsekrację z r. 1766, rzymski dekret erekcyjny z r. 1739, zgode ordynariusza Diecezji Krakowskiej na poświęcenie kamienia węgielnego z r. 1740 oraz świadectwo komisarza dóbr ziemskich fundatora o zamianie gruntów pod budowę klasztoru. W odpisie w. w. inwentarza z r. 1885 znajdują się jeszcze dwa dokumenty: dekret cesarski przyznający klasztorowi 39 sągów drzewa z lasów bratkowickich, dawniej królewskich, a w r. 1827 bar. de Kronegg i wykaz niewielkich działek gruntu będących w posiadaniu klasztoru od r. 1820.

Na podstawie pozostałych aktów trudno stwierdzić, czy kancelaria klasztorna posiadała akta usystematyzowane według grup rzeczowych. Pewne jest, że przeważna część aktów sẹdziszowskich uległa zniszczeniu w r. 1914 wraz z aktami prowincji w Krośnie. Można również przypuszczać, że najdawniejsze akta i część nowszych, znajdujące się w klasztornej bibliotece, przepadły wraz z książkami w dobie józefińskiej. Zaginęla wtedy również pierwsza kronika klasztorna obejmująca dzieje konwentu od r. 1739-1775.

Do rozwiązania $w$ koncu pozostaje zagadnienie jedynej zachowanej karty kroniki z r. 1818-1820, spisanej w języku polskim i uwzględniającej problemy całej prowincji, z wyszczególnieniem dziejów konwentu sędziszowskiego (por. niżej AKS 3 poz. 12). Kronika sędziszowska z tych lat (t. II) jest pisana w jęz. łacińkim i zacieśnia się raczej do spraw samego klasztoru, podając $\mathrm{w}$ mniejszym stopniu fakty $\mathrm{z}$ życia prowincji i z szerszej areny politycznej. Można więc przypuszczać, że karta z lat 1818-1820 pochodzi z nieznanej dziś kroniki prowincji.

\section{Opracowanie}

Dokumenty i część aktów znaleziono w skamieniałym klocku wydobytym z ziemi w r. 1914 w Krośnie. Część aktów przejęto z biblioteki sę- 
dziszowskiej. W niej również znalazła się druga kronika klasztoru, uważana już za zaginioną. Stamtąd pochodzą także wszystkie pozostałe rękopisy. Kronikę IV i V przejęto obecnie z kancelarii klasztornej. Niewielka ilość aktów dawnych pozostala jeszcze w kancelarii klasztornej w schowku kasy pancernej.

Wszystkie akta i rękopisy uszeregowano w miarę możności weuług opisanego na wstępie schematu.

Odtworzone w ten sposób archiwum klasztorne obejmuje $1 \mathrm{mb}$. akt i w dostateczny sposób ilustruje dzieje konwentu i jego mieszkańców.

\section{Zawartość archiwum}

AKS 1. Dokumenty fundacyjne. 1738-1756. $36.2 \times 24.8 \mathrm{~cm}$, płsk., klb. 23, knlb. 1 .

A.KS 2. "Ustawy do zachowania w Prowincyi naszey oboiey Gallicy stosownie do Reguły i Konstytucyi naszych Braci Mnieyszych S. Franciszka Kapucynów. Podług Dekretu Reformationis uchwalonego na Kapitule przy połączeniu Klasztorów oboiey Gallicyi w iedne Prowincyą S. S. Woyciecha Biskupa i Jana Nepomucena Męczenników, odprawioney w Szędziszowskim naszym Klasztorze, za iednomyślnym zezwoleniem Rządu, Dyecezanow i wszystkich Oyców Kapitularnych. Zebrane i ułożone Roku Pańskiego 1806". $24.5 \times 19.5 \mathrm{~cm}$, płsk., slb. 34 .

AKS 3. Akta różne. 1777-1936:

1. Dokumenty autentyczności relikwii. 1780-1867. K. 1--4.

2. Dokumenty odpustowe. 1777-1868. K. 5-8.

3. Akta prowincjalskie. 1868-1935. K. 9-16.

4. Akta konsystorskie. 1804-1923. K. 17-29.

5. Akta dziekańskie. 1831-1887. K. 30-41.

6. Pisma klasztoru do władz świeckich. Zarządzenia władz świeckich. 1800-1888. K. 42-80.

7. Tabele osobowe konwentu. 1891-1906. K. 81.

8. Wykaz zakonników do schematyzmu, 1832. K. 82.

9. Wykaz nowicjuszy. 1823-1824. K. 83.

10. „Karta oznajmiająca dla obliczenia ludności i zwierząt". [1869]. K. 84-86.

11. Swiadectwa moralności wystawione służącym. 1878-1879. K. 87-88.

12. Karta z nieznanej kroniki. 1818-1820. K. 89. 
13. Sprawa dzieł św. Bonawentury. Spis podręczników gimnazjalnych znajdujących się w bibliotece. 1871. K. 90-96.

14. Korespondencja gwardianów, 1838-1934. K. 97-156.

15. "Realitates Conventus". [1803-1804]. K. 157-158.

16. Kopia inwentarza z r. 1924. K. 159-163.

$36.3 \times 24.8 \mathrm{~cm}$, płsk., klb. 163 , knlb. 20.

AKS 4. "Mortuologium P. P. ac F. F. nec non Fundatorum ac Benefactorum nostrorum Ordinis Minorum S. P. Francisci Capucinorum in Provincia Galliciae defunctorum conscriptum pro Conventu Sendziszoviensi 1827". [1827-1955].

$28.4 \times 21.5 \mathrm{~cm}$, płperg., slb. 359 .

AKS 5. "Copia Inventarii Buchhalterici de anno 1827 facti in Conventu Sendziszoviensi PP. Capucinorum. Sub Nro 185". $38 \times 24.5 \mathrm{~cm}$, pap. zniszcz., slb. 98 .

AKS 6. „Inventarium des in dem Orte Sędziszów - Rzeszower Kreises gelegenen - zur Przemyśler lat. Diecös gehörigen Kapuziner $=$ Klosters zu Sędziszów. Welches im Grunde $k$. Gub. Verordnung vom 13 Juni 1826 Z. 30827 und k. kreisamtlichen Auftrags vom 14 November $1826 \mathrm{Z} .8972$ neu aufgenommen worden ist. Zu Sędziszów am 14 September 1827. Copia Inventarii tempore Guardianatus P. Floriani ab Haczów facta a. 1885 . d. $11 / 12^{\prime \prime}$.

$33.5 \times 21.3 \mathrm{~cm}$, pap. zniszez., slb. 175 .

AKS 7. „Regestr słuźących”. [1726-1855].

$24.2 \times 10 \mathrm{~cm}, \mathrm{p} ł \mathrm{sk} ., \mathrm{klb} .42$, knlb. 5 .

AKS 8. Księga wpisowa do Bractwa Różańca św., Niepokalanego Poczęcia N.M.P. oraz Paska św. Franciszka. 1858-1875. $22.5 \times 19.2 \mathrm{~cm}$, pap., slb. 56.

AKS 9. Książka wpisowa Bractwa N. Serca P. Jezusa, Serca M. B., Szkaplerza Niepokalanego Poczęcia, Różańca św., Paska św. Franciszka i Tercjarstwa. 1875-1899.

$41.7 \times 17 \mathrm{~cm}$, pł., slb. 303 .

AKS 10. Księga Bracka: Szkaplerz św. Józefa. Szkaplerz Serca Jezusowego. Szkaplerz M. B. Karmelitańskiej. Szkaplerz i Koronka Niepokalanego Poczęcia. Różaniec. Milicja Niepokalanej. XIX i XX w.

$32.3 \times 20 \mathrm{~cm}$, pl., slb. 233.

AKS 11. Księga Bracka: Szkaplerz Niepokalanego Poczęcia N.P.M. i Koronka. XIX i XX w. $40.7 \times 16 \mathrm{~cm}, \mathrm{pk}$, slb. 212. 
AKS 12. Historia tercjarstwa w Sędziszowie i okolicy. Spisy tercjarzy. XIX i XX w. $20.5 \times 17.5 \mathrm{~cm}$, bez opr., klb. 45.

AKS 13. "IIf Zakon". [Spis tercjarzy z okręgu sędziszowskiego. XX w.]. $28 \times 11 \mathrm{~cm}$, pkpł., slb. 95.

- AKS 14. "Cathalogus librorum". [1827].

39.8 × $25 \mathrm{~cm}$, płsk., slb. 52, knlb. 2.

AKS 15. Sprawy majątkowe. 1784-1936:

1. Hipoteka. 1877-1878. K. 1-5.

2. Zamiana gruntów w Górze Ropczyckiej. 1869. K. 6-8.

3. Wykaz dochodów i rozchodów. 1784-1860. K. 9-14.

4. Kontrakty i dzierżawy. 1881. K. 15-16.

5. Podatki. 1851-1886. K. 17-56.

6. Dotacje. 1886-1913. K. 57-61.

7. Legaty. Testamenty. 1833-1919. K. 62-98.

8. Kwity. 1828-1887. K. 99-138.

9. "Książeczka udziałowa sklepu Kółka Rolniczego w Sędziszowie". [1912. Rachunki. 1925-1936]. K. 139-156.

10. Kwity. 1877-1936. K. 157-180.

$36.2 \times 24.5 \mathrm{~cm}$, płsk., klb. 180, knlb. 12.

AKS 16. "W "Wchód i Przychód pieniężny od zaczęcia Gwardyaństwa O. Floryana, który się poczena od dnia 1-o września 1822 ". [1822-1829].

$37.5 \times 12 \mathrm{em}$, płsk., sib. 92.

AKS 17. "Książka podręczna dochodów i rozchodów". [1930-1934]. 20.6 × $16.5 \mathrm{~cm}$, płpł., slb. 198.

AKS 18. "Datki na budowę klasztoru". [1929-1930].

$35.5 \times 22 \mathrm{~cm}$, pl., slb. 266 , zapis. 149.

AKS 19. "Liber Sacrarum Missarum ratione Caes. Reg. Aerarii absolutarum. Anno 1837 perfectus. 1806-1847 ${ }^{i}$.

$34.8 \times 22 \mathrm{~cm}$, płsk., slb. 65 .

AKS 20, "Liber Missarum absolutarum ab Anno 1826". [1826--1851]. $37.5 \times 12 \mathrm{~cm}$, płsk., slb. 375 .

AKS 21. "Liber Stipendiorum pro Sacris Missis absolvendis, libere oblatorum. Die 20a 7bris 1837 factus". [Od str. 74 do 80 legaty. 1837-1869].

$33 \times 21 \mathrm{~cm}$, pł., slb. 83, snlb. 2 .

AKS 22. "Liber Missarum absolutarum ab Anno 1851". [1851-1884]. $37.5 \times 12 \mathrm{~cm}$, plsk., slb. 410 .

AKS 23. "Liber Missarum". [1872-1892].

$38.5 \times 24 \mathrm{~cm}, \mathrm{p}\}$, slb. 156 . 
AKS 24. "Liber Missarum". [1876-1911].

$20.3 \times 17 \mathrm{~cm}$, pł., slb. 334 .

AKS 25. "Liber Missarum". [1892-1906].

$33.5 \times 21 \mathrm{~cm}$, płpł., slb. 151.

AKS 26. "Książka mszalna". [1900-1906].

33 x $15.5 \mathrm{~cm}$, pł., slb. 194.

AKS 27. "Fundacye mszalne wieczyste klasztoru Sendziszowskiego. Wypisano ż książki mszalnej. 1898". [1898-1934].

$38.5 \times 24.5 \mathrm{~cm}$, pisk., slb. 38 , snlb. 2.

AKS 28. „Protocollum Publicandorum P. P. Capucinorum Conventus Sędziszoviensis ab Anno 1777". [1777-1797].

Brak tylnej okładziny.

$19.4 \times 16.5 \mathrm{~cm}$, płsk., zniszcz., slb. 298.

AKS 29. „Liber Cursoriarumque varii generis Decretorum ad Conventum Sendziszovierisem adventantium incipiendo ab Anno 1810 ulteriorique serie adnotatorum. Anno 1837 perfectus". [18241873].

$38.2 \times 24.5 \mathrm{~cm}$, płsk,, slb. 164 .

AKS 30. "Księga Rozporządzeń. Rok 1909". [Od r. 1909].

$33.6 \times 20.5 \mathrm{~cm}, \mathrm{pł}$, slb. 403 , zapis. 181 .

AKS 31. "Plany rozbudowy klasztoru". [1924-1929].

$36.2 \times 24 \mathrm{~cm}$, płsk., planów 11 .

AKS 32. "Synopsis exhibitorum". [1842-1850].

$20.7 \times 16.3 \mathrm{~cm}, \mathrm{pl}$, slb. 24 .

AKS 33. "Prothocollum gestionis, exhibitorum, expeditionum ac relationum qualiumcumque in Conventu Sendziszoviensi Ordinis S.P.N. Francisci Capucinorum. Die 1 Octobris 1834 factum". $39.3 .24 \mathrm{~cm}$, płperg., slb. 106.

AKS 34. „Historia Conventus. Tomus Secundus. [Wkładka między str. 266-267: Stan prowincji galicyjskiej z r. 1848. 1776-1863]. $33.8 \times 20.5 \mathrm{~cm}$, płsk., slb. 267.

AKS 35. "Kronika klasztoru OO. Kapucynów w Sędziszowie. T. III”. [1887-1914].

$28.7 \times 22 \mathrm{~cm}$, płsk., slb. 265.

AKS 36. "Kronika klasztoru OO. Kapucynów w Sędziszowie. T. IV". [1914-1919].

$33.8 \times 20.2 \mathrm{~cm}$, płpł., slb. 308 .

AKS 37. „Kronika klasztoru OO. Kapucynów w Sędziszowie, od 1/VI 1919 do 31. XII. 1935. T. V".

$33.8 \times 20.2 \mathrm{~cm}$, płpł, pag. od s. $297-598$.

AKS 38. „Kronika klasztoru OO. Kapucynów w Sędziszowie od 1.I.1936.

T. VI".

$43 \times 24,2 \mathrm{~cm}$, płpl., slb. 597 , zapis. 


\section{ARCHIWUM KLASZTORU W OLESKU}

\section{Historia klasztoru}

W r. 1725 dobra oleskie wraz z historycznym zamkiem - miejscem urodzenia Michała Korybuta Wiśniowieckiego i Jana Sobieskiego - kupił od Jakuba Sobieskiego hetman wielki koronny Stanisław Mateusz Rzewuski. W r. 1728 majątek odziedziczył syn hetmana Józef Seweryn Rzewuski, fundator klasztoru. Po jego'śmierci Wacław Rzewuski, rodzony brat fundatora, połączył dziedzictwo oleskie z dobrami podhoreckimi. Wacław zmarł w r. 1796 a zamek oleski wraz ze wsiami Czechy, Czyszki i Sewerynka przeszedł drogą licytacji w ręce Aleksandra Zielińskiego. Z kolei majątek stał się własnością zięcia Zielińskiego Wojciecha Lityńskiego, zmarłego w r. 1841. Po nim majątek obejmuje Zofia Lityńska (\$1868). Po jej śmierci majątkiem zarządza jej mąż Zarucki. Ostatecznie zamek wraz z 17 morgami ziemi nabył w r. 1883 Wydział Krajowy i przystąpił do restauracji zniszczonego zabytku.

Wstęp powyższy potrzebny jest dla zrozumienia losów fundacji kapucyńskiej w Olesku zrealizowanej w r. 1739. Fundator wraz z bratem byli całkowicie oddani zakonowi. Ale nie zabezpieczyli na drodze prawnej własności fundacji i deputatów dla klasztoru. Błąd ten zemścił się w niedalekiej przyszłości. Już bowiem po śmierci Wacława Rzewuskiego nabywca majątku Aleksander Zieliński odmówił wydawania deputatów drzewa i zażądał zwrotu sadzawki, łąk i gruntu za murami klasztoru, mimo iż obiekt ten stanowił jedyne źródło utrzymania konwentu. Następca Zielińskiego poszedł $\mathrm{w}$ jego ślady. Od r. 1862 procesy o deputaty drzewa z lasów Oleska, Czyszek i Sewerynki są na porządku dziennym. Sprawy te; jakkolwiek regulowane przez sądy na korzyść klasztoru, ciągnęły się przez długie latạ i niepokoiły zakonników. Dopiero kontrakt zawarty z kolejnym nabywcą dóbr Wiktorem Jasinskim w dniu 1 marca 1926 r. położył kres sporom. Jasiński wydzielił 23 morgi lasu i oddał klasztorowi jako ekwiwalent za coroczny deputat drzewa.

Fundacją w Olesku zajął się na zlecenie zakonu o. Andrzej z Szydłowca. O. Andrzej (Marcin Dobrawski) urodził się 15 listopada $1694 \mathrm{r}$. w Szydłowcu na Podolu. Do zakonu wstąpił 5 lutego 1719 w Krakowie a zmarł w Olesku 15 października 1768 r. Założyciel klasztoru widocznie z wielkim zamiłowaniem przystąpił do pracy, jeśli pod jego bezpośrednim nadzorem powstał najpiękniejszy dom kapucyński w Polsce. Całość obiektu architektonicznego z przylegającym ogrodem zajmowała taką samą powierzchnię jak bazylika św. Piotra w Rzymie. 
Fundator zapewnił konwentowi odpowiednie podstawy materialne a sam kościół i klasztor zaopatrzył we wszystko, co potrzebne było do spełniania funkcji religijno-zakonnych. Z czasern kościół otrzymał cenne obrazy Czechowicza oraz bogate paramenty, klasztor zaś bogatą bibliotekę i aptekę zaopatrzoną w duży wybór medykamentów. W ogrodzie fundator kazał wystawić pięć stylowych altan i ozdobić freskami. Dwie sadzawki w ogrodzie miały dostarczać świeżej ryby.

W nowym konwencie św. Józefa zakwitło zakonne życie. W krótkim czasie zorganizowano studia filozoficzno-teologiczne a liczne dysputy wsławiły oleską szkołę zakonną wysokim poziomem nauki.

Kapucyni z nowej placówki dali się poznać na daleką okolice przez akcję misyjną, charytatywną i patriotyczną. Słynęli szeroko jako kaznodzieje. Byli również poszukiwani jako medycy a klasztorna apteka zdobyła zasłużony rozgłos.

W klasztorze tym zmarł znany kaznodzieja i kapelan króla Stanisława Leszczyńskiego o. Klemens Grygielski.

Klasztor został skasowany w r. 1785. Rozgrabiono wtedy częściowo wyposażenie kościoła, przepadło archiwum i biblioteka, nawet trumny fundatorów i zakonników usunięto z krypt kościelnych.

W klasztorze umieszczono szpital wojskowy. Wydawało się, że klasztor nie podniesie się już z upadku. Ale koniec nie był mu jeszcze pisany, albowiem na prośbę kapucyńskiego komisar̨a prowincjalnego cesarz Józef II nakazał kapucynom oddać z powrotem klasztor. Dnia 30 stycznia 1788 o. Honorat Czuryło na rozkaz władz zakonnych objął klasztor w posiadanie. Od tej chwili konwent spełniał funkcję wikarego miejscowej parafii. Zakonnicy pomagali okolicznym duszpasterzom w pracy parafialnej. Uczyli również w miejscowych i sąsiednich szkołach.

Klasztor oleski w dziejach prowincji galicyjskiej i krakowskiej uwa* żany był przez współbraci niemal za miejsce zsyłkowe, zwane najczęściej "Syberią". W latach przed 1939 r. stał się wakacyjnym miejscem wypoczynku dla kleryków. Przetrwał aż do r. 1944 ale złoty okres z pierwszych lat fundacji już się nie powtórzył.

\section{Historia archiwum}

Zespół archiwalny klasztoru kapucyńskiego w Olesku jest bardzo wartościowy, ponieważ naświetla wiele faktów z historii prowincji, o których brak innych archiwalnych przekazów. Jest to bodaj najcenniejsze archiwum kapucyńskie w granicach prowincji krakowskiej. 
Właściwy zrąb archiwum oleskiego obejmuje szczątkowe akta z czásów prowincji galicyjskiej i krakowskiej. Ważną usługę może oddać badaczowi rękopis „Processus Loci Ordinarii et Circularia Officii Circilaris a die 22 Julii 1782 anni sub regimine P. Alexandri Guard. Leop. et Commissarii". Zawiera rozporządzenia konsystorza Iwowskiego i władz świeckich od r. 1782 do 1803. Brak jednak rozporządzeń władz zakonnych. Może dlatego, że klasztory zostały podporządkowane ordynariuszom diecezjalnym. Ponieważ z tego okresu brak wielu oryginalnych aktów, „Processu.s Loci Ordinarii..." może spełniać rolę zastępczą. Należał on do archiwum konwentu lwowskiego. Po kạsacie konwentu we Lwowie przekazany został bibliotece klasztoru oleskiego. W r. 1826 był zarejestrowany $\mathrm{w}$ inwentarzu bibliotecznym pod nr. 39. Obecnie powrócił do macierzystego choć najuboższego archiwum (por. AKL 2).

Zespół archiwum oleskiego wynosi $1 \mathrm{mb}$. akt. Składa się z trzech części. Pierwsza część to akta ułożone chronologicznie, zawarte w sześciu fascykułach. Druga część, w układzie rzeczowym, obejmuje fascykuły od 7 do 10. Pierwsza i druga część mają oddzielne "Synopsis exhibitorum". Trzecia część składa się z mortuologium, ksiąg mszalnych, protokołu, kronik oraz z rękopisów bibliotecznych.

Część pierwsza obejmuje lata 1782-1844. Została połączona w tomy dla podręcznego użytku w kancelarii prawdopodobnie za rządów gwardiana o. Kryspina Wróblewskiego. Całość pierwszej części została podzielona na sześć fascykułów a każdy akt otrzymał kolejny numer bieżący $\mathrm{w}$ porządku chronologicznym. Za repertorium służyło dokładnie opracowane "Synopsis exhibitorum" 1782-1844, dające dokładny przegląd zawartości poszczególnych aktów. Na uwagę zasługuje streszczenie każdego aktu w jego oryginalnym języku, a więc łacińskim, polskim lub niemieckim. Takie opracowanie aktów było potrzebne i wystarczające do użytku bieżącego w kancelarii klasztornej. Obecinie odtworzono ten dawny układ kancelaryjny, zgodnie $\mathrm{z}$ zasadami opracowywania zbiorów archiwalnych.

Zaznaczyć jednak należy, że jest to jedyny przykład układu chronologicznego w aktach klasztornych całej prowincji galicyjskiej. Wydaje się, że i w dawnej kancelarii nie był zbyt użyteczny, stwarzał bowiem gęsty las aktów, przez które trzeba było przedzierać się z wielkimi oporami. "Synopsis exhibitorum" zaledwie ułatwiało tę pracę. Nie trzeba się więc dziwić, że w następnych latach zarzucono system chronologiczny jako niepraktyczny.

Dlatego też drugiej części zawartości archíwum (1787-1943) nadano układ rzeczowy. Taki układ jest zgodny z układem praktykowa- 
nym w kancelarii klasztornej po roku 1844. Zastosowano go wtedy ze względu na praktyczność i przejrzystość. Nie można było jednak wiernie odtworzyć tego układu, ponieważ inwentarz drugiej części nie istniał nigdy a zachował się tylko niepełny zresztą dziennik podawczy. Pozostały wprawdzie w poszczególnych wypadkach orientacyjne napisy na odwrocie aktów, atoli są one zbyt skąpe, by na ich podstawie można było odbudować dokładnie układ pierwotny drugiej części zespołu. Schemat drugiej części trzeba było wypracować niezależnie od dawnego układu. Dodatkową trudność sprawiały akta bez numeracji, które chronologicznie należą do pierwszej części ale, ponieważ nie zostały zaszeregowane do części pierwszej, teraz z konieczności musiały pozostać w części drugiej. Nie można dzisiaj rozbijać pierwszej zwartej części. Możemy tylko postawić pytanie, dlaczego twórca pierwszej części archiwum nie włączył wszystkich aktów do sześciu fascykułów. Może dla tego, że akta początkowo zaginęły i odnalazły się już po opracowaniu pierwszej części, albo też - co jest bardziej prawdopodobne - były potrzebne do przeprowadzania sporów sądowych o własność klasztoru. Wyłoniło się jeszcze dodatkowe zagadnienie, jak postąpić z aktami współczesnymi, których jest najmniej.

Problemy powyższe rozwiązano w następujący sposób. Rozporządzenia władz kościelnych, zakonnych i świeckich ujęto oddzielnie w fascykuł 7 (1787-1885). Akta różne dotyczące przeważnie organizacji klasztoru, życia religijnego, kulturalnego i obrony własnych interesów umieszczono w fascykule 8 (1788-1923). W 9 fascykule (18121923) znalazły miejsce akta podatkowe, dotacje $z$ funduszu religijnego oraz kwity rachunkowe. W 10 fascykule pomieszczono archiwalia współczesne (1909-1943), grupę najsłabiej reprezentowaną, aby jej nie mieszać z aktami starymi, wymagającymi więlsszej ochrony.

W ostatniej części wreszcie umieszczono rękopisy biblioteczne, które, ze względu na swoją wartość i związek z dziejami klasztoru, winny wejść w skład zespołu.

Po skonfrontowaniu zachowanej części archiwum oleskiego z zawartością inwentarza z r. 1833 trzeba zaznaczyć pewne braki. Nie ma mianowicie pozycji: 1. „Liber decretorum ac omnium ordinationum ab anno 1827 usque ad annum 1833"; 2. "Prothocolum actorum seu synopsis exhibitorum perceptorumque et expeditionum ab anno 1769 usque ad annum 1833" ' (z tego rękopisu zachowała się cząstka obejmująca niekompletne zapisy od r. 1782 do 1844); 3. „Liber regestorum perceptorum expensarumve ab anno 1816 ad annum 1833". Oprócz wykazanych ubyt- 
ków zaginęła pewna ilość innych akt dawnych. We współczesnych natomiast aktach brak zagadnień majątkowych, procesowych, księgi dochodów i rozchodów oraz kwitów. Archiwalia te przepadły bezpowrotnie.

Mimo poważnych braków pozostałe akta w dostateczny sposób naświetlają dzieje klasztoru z okresu jego przynależności do prowincji galicyjskiej a póżniej krakowskiej. Źródeł do okresu przynależności do prowincji polskiej (po zaginięciu pierwszej kroniki w czasie kasacji) dostarczy częściowo "Historia Conventus Olescensis", odtworzona w r. 1806 oraz materiały znajdujące się w innych zbiorach.

\section{Za a a tość archiwum}

AKO 1. Akta klasztoru. T. I. (Akta od nr 2 do 76; brak nr 1, 58 i 77). $1782-1810$. $40.3 \times 25.5 \mathrm{~cm}$, płpł., klb. 112 , knlb. 4.

AKO 2. Akta klasztoru. T. II. (Od nr 78 do 173). 1811-1824. $42 \times 25.5$ cm, płpł., klb. 165, knlb. 4.

AKO 3. Akta klasztoru. T. III. (Od nr 1 do 80). 1825-1830. $42 \times 25.2 \mathrm{~cm}$, płpł., klb. 130, knlb. 4.

AKO 4. Akta klasztoru. T. IV. (Od $\mathrm{nr} 1$ do 110). 1831-1834. $40 \times 25 \mathrm{~cm}$, płpł, klb. 171, knlb. 1 .

AKO 5. Akta klasztoru: T. V. (Od nr 1 do 82; brak nr 24). 1835-1840. $42.5 \times 25.4 \mathrm{~cm}$, plpk., klb. 127, knlb. 4.

AKO 6. Akta klasztoru. T. VI. (Od nr 1 do 45; brak nr 5 i 12). 1841 -1844 . $37 \times 24 \mathrm{~cm}$, płpł., klb. 56, knlb. 4.

AKO 7. Akta klasztoru. T. VII. 1787-1885:

1. „Ordinationes consistoriales et decanales". [1841-1875]. K. $1-41$.

2. Zarządzenia władz świeckich. 1787-1876. K. 42-62.

3. "Acta generalia". [1843-1884]. K. 63-119.

4a. "Acta provincialia". [1837-1879]. K. 120-162.

4b. Encyklika wikarego prowincjalnego. 1830. K. 163-166.

4c. Zawiadomienia o kapitule. 1840-1885. K: 167-174.

4d. Wykaz zakonników i tabele na kapitułę. 1799-1816. K. $175-176$.

4e. Tabele zmian personalnych na kapitule. 1846-1885. K. $177-179$.

4f. Obediencje prowincjalskie. 1840-1849. K. 180. 
4g. Encykliki prowincjalskie. 1840-1849. K. 181-185.

4h. Zarządzenia $\mathrm{w}$ związku $\mathrm{z}$ kongregacją definitorialną. 1853-1856. K. 186-187.

5. Przywileje. 1880. K. 188.

6. Pisma gwardiana do prowincjała, 1866. K. 189-191.

7. Korespondencja gwardianów. 1850-1883. K. 192-197. 40.5 × $25 \mathrm{~cm}$, płpł., klb. 197, knlb. 5.

AKO 8. Akta klasztoru. T. VIII. 1788-1923:

8. "Regestr dochodów i rozchodów". [1810-1851]. K. 1-10.

9. Ofiary w odpust św. Antoniego, intencje i akafisty. 1899. K. $11-13$.

10. Msze św. odprawiane na intencje klasztoru. K. 14-15.

11. Intencje mszalne. K. 16-38.

12. Wydatki, 1878, K. 39-42.

13. Sprawa tabaki. 1877. K. 43.

14. Braki w inwentarzu z r. 1840. K. 44.

15. Regestr różnych rzeczy w klasztorze. 1812. K. 45-52.

16. Inwentarz klasztoru i kościoła. 1821. K. 53-56.

17. Trzy inwentarze klasztoru, kościoła i biblioteki z lat 1826 i 1850 . K. 57-94.

18. Inwentarz książek w bibliotece klasztornej. 1826. K. 95116.

19. Hipoteka. K. 117-140.

20a. Sprawy sądowe contra Lityński o serwitut drzewa z lasów Oleska. 1862-1893. K. 141-163.

20b. Sprawy sądowe contra Skrzyszowscy z Czyszek o deputat drzewa z fundacji. 1862. K. 164-169.

20c. Sprawy sądowe contra Karol Zagórski. 1871. K. 170.

20d. Sprawy sądowe. Al. Zieliński contra klasztor o sadzawkę, łąki i grunta za murami. 1799. K. 171-172.

20e. Sprawy sądowe contra Ujeński o deputat drzewa w Sewerynce i Czyszkach. 1843-1905. K. 173-194.

21. Testament ks. W. Kochaczewskiego. 1848, K. 195.

22. Ubezpieczalnia. 1889-1931. K. 196-213.

23. Reperacje klasztoru. 1788-1881. K. 214-218. $40.5 \times 25.5 \mathrm{~cm}$, płpł., klb. 218, knlb. 5 .

AKO 9. Akta klasztoru. T. IX. 1812-1923:

24. Podatki. Dotacje rządowe. 1844-1911. K. 1-129.

25. Kwity rachunkowe. 1812-1923. K. 130-223. $40.1 \times 25.5 \mathrm{~cm}$, płpl., klb. 223 , knlb. 4 . 
AKO 10. Akta klasztoru. T. X. 1909-1943. (Akta wspólczesne):

26. Rozporządzenia prowincjalskie. 1914-1943. K. 1-81.

27. Inwentarz klasztoru. 1936 (?). K. 82-84.

28a. Rozporządzenia konsystorza. 1920-1943. K. 85-88.

28b. Władze świeckie. 1908-1923. K. 89-95.

28c. Starania o zwolnienie opłat od pastwiska. 1910-1912. K. 96-106.

28d. Spółka wodna dla osuszenia błot. 1901-1909. K. 107-113.

28e. Restauracja kościoła i budowa wieżyczki. 1909-1912. K. $114-138$.

35.7 x $22.5 \mathrm{~cm}$, płpł, klb. 138, knlb. 5 .

AKO 11. Kurendy i listy pasterskie arcybiskupów lwowskich. 1842-1935.

Druki, 31.5 x $26 \mathrm{~cm}$, płsk., klb. 128, knlb. 1 .

AKO 12. „Mortuologium seu Calendarium Patrum et Frum Ordnis S. F. N. Francisci Capucinorum in Provincia olim Polona mortuorum conscriptus. Anno Domini 1807. Pro Conventu Olescensi".

$22 \times 17.5 \mathrm{~cm}$, sk., slb. 378 .

AKO 13. „Kontrakt ze służącymi“. [1794-1823].

$21.2 \times 19.5 \mathrm{~cm}, \mathrm{sk} ., \mathrm{klb} .17$.

AKO 14. "Książka służących klasztoru oleskiego". [1844-1858].

$17.5 \times 10.5 \mathrm{~cm}$, pap., klb. 39 .

AKO 15. "Liber infirmorum in parochia Olescensi". [1907-1944].

$32.7 \times 20.5 \mathrm{~cm}$, p?p., klb. 14.

AKO 16. "Spis książek należących do biblioteki OO. Kapụcynów w Olesku".

33.5 × $20.5 \mathrm{~cm}$, płsk, klb. 59 .

AKO 17. "Liber missarum". [1825-1835].

$39 \times 12.6 \mathrm{~cm}$, płpł., slb. 130 .

AKO 18. "Regestrum absolutarum missarum". [1835-1853].

$38 \times 11.5 \mathrm{~cm}$, płsk., slb. 311, knlb. 6 .

AKO 19. "Zapiski różne. Liber novitiorum". [Kwity. 1855-1878].

$21 \times 16.5 \mathrm{~cm}$, pap., kilb. 28.

AKO 20. „Plan gospodarczy lasu OO. Kapucynów w Olesku“. [19311938].

$34 \times 21 \mathrm{~cm}$, plpł., klb. 13.

AKO 21. "Liber variarum ordinationum ab anno 1859". [Doprowadzony do r. 1942].

$33.7 \times 21 \mathrm{~cm}$, płsk., slb. 355 , zapis. 282. 
AKO 22. "Synopsis exhibitorum". [1782-1844].

$36.7 \times 25.4 \mathrm{~cm}$, płpł., klb. 17, knlb. 1.

AKO 23. "Synopsis exhibitorum". [1838-1851].

$20 \times 16 \mathrm{~cm}$, płpł., slb. 60 , knlb. 3.

AKO 24. "Synopsis exhibitorum et expeditorum". [1860-1892]. $37.5 \times 23.5 \mathrm{~cm}$, płpł., sib. 40 , knlb. 9.

AKO 25. „Historia Conventus Olescensis“. [1739-1862. Odtworzona częściowo w r. 1806].

35.8 x $21.5 \mathrm{~cm}$, sk., slb. 62 , knlb. 3 .

AKO 26. „Kronika klasztoru OO. Kapucynów w Olesku”. [T. II. 1908 -1933].

$25.2 \times 20 \mathrm{~cm}$, płsk., slb. 300, knlb. 4 .

AKO 27. "Kronika klasztoru OO. Kapucynów w Olesku od roku 1933". [Do r. 1944. T. III].

$33.5 \times 20.5 \mathrm{~cm}$, płsk., slb. 88 , knlb. 1 .

AKO 28. "Libellus variarum compositionum latinarum. Ad M.D. G. V. J.C. M. H. S. P.P. venerationem conscriptus specialiter vero aeternae Sapientiae Matri dedicatus per Frm Andream a Podolia sacerdotem capuccinum licet indignum. Varsaviae scribi inchoatus. Inchoato anno salutis nostrae $1724^{\prime \prime}$. $15.9 \times 9,7 \mathrm{~cm}$, płsk., slb. 263 .

AKO 29. Poezje religijne $\mathrm{w}$ jęz. polskim i częściowo w łacińskim. Brak karty tytułowej. Prawdopodobnie autorstwa o. Andrzeja Dobrawskiego. 18.5. x $12 \mathrm{~cm}$, sk., slb. 290.

AKO 30. "Zabawy duchowne różnego pytania nauki chrześciańskiej katolickiey rzymskiey zebrane a każdemu chrześciańskiemu człowiekowi do dostąpienia żywota wiecznego potrzebne. Roku Pańskiego tysiącznego siedmsetnego siedmdziesiątego pierwszego. X. Józef Nowakowski mpp."

Powyższy katechizm kupił w r. 1860 w Załoźcach ks. A tanazy Switecki kap. $17 \times 9 \mathrm{~cm}$, sk., slb. 448 , knlb. 75 .

V. ARCHIWUM KLASZTORU W ROZWADOWIE

1. Historia klasztoru

Nowa fundacja klasztoru OO. Kapucynów w Sędziszowie przyczyniła się do powstania klasztoru w Rozwadowie. Książę Jerzy Ignacy Lubomirski, pan na Wiśniczu i Jarosławiu, generał wojsk królewskich, dziedzic Rozwadowa itd., na wieść o budowie klasztoru w Sędziszowie 
postanowił wznieść "pro gloria Dei“ konwent w swoich dobrach dziedzicznych. Z wielką energią i nakładem kosztów zabrał się do przeprowadzenia swoich planów. Już w r. 1740 załatwił wszystkie formalności prawne $\mathrm{z}$ władzami zakonnymi i kościelnymi. Dnia 18.VI.1741 r. przybyli do Rozwadowa pierwsi kapucyni, ażeby założyć hospicjum. W tym samym roku zbudowano pierwszą drewnianą kaplice i hospicjum. W szybkim tempie rozpoczęto wstępne prace. Kamien węgielny pod gmach kościoła i klasztoru położył i poświęcił w dniu 7.VII.1743 proboszcz rudnicki ks. Jan Kokoszyński. W tym samym roku spłonęła drewniana kaplica wraz $\mathrm{z}$ hospicjum. Budowa obiektów $\mathrm{z}$ trwałego materiału trwała jedenaście lat. W pierwszych latach budowy doszło do tragicznego wypadku. Architekt Jan Opitz założył wadliwie fundamenty, wskutek czego w r. 1745 mury runęły. Przestraszony architekt uciekł potajemnie. Fundator sprowadził wtedy architekta Jana Bay z Warszawy, który na nowo założył fundamenty i doprowadził budowę fundacji do końca. Dnia 14.X.1753 r. bp Franciszek Potkański sufragan krakowski dokonał aktu konsekracji kościoła. Tego też dnia książę Teodor Lubomirski, syn fundatora przekazał zakonowi klucze fundacji.

W kruchcie nad wielkimi drzwiami na drewnianej tablicy oraz $\mathrm{w}$ chórze pod medalionem $\mathrm{z}$ wizerunkiem Lubomirskiego umieszczono następujący wotywny napis fundatora:

„WIENSZUJEĆ, MOJA NAYŚWIETSZA PANNO SZCZEŚLIWEY MINUTY KTÓRĄ̧ MIAŁA, KIEDYŚ SIE POCZEŁA W ŻYWOCIE ANNY Ś. PROSZE CIE PRZEZ TE SZCZEŚLIWA MINUTE; RACZ MNIE POCIESZYC W GODZINE SMIERCI MOIEY. ZDROWAŚ MARYA ŁASKI PEENA, PAN Z TOBA, BŁOGOSEAWIONAŚ TY MIEDZY NIEWIASTAMI Y BEOGOSEAWION OWOC ŻYWOTA TWOIEGO JEZUS. SWIETA MARYA MATKO BOŻA MÓDL SIE ZA NAMI GRZESZNEMI TERAZ Y W GODZINE SMIERCI NASZEY. AMEN".

W prawej nawie nad drzwiami bocznymi, prowadzącymi z krużganków klasztornych do kościoła, widnieje na marmurowej tablicy napis:

D O M

Hic jacet Peccator, hujus Loci Fundator, ora Deum, ut hunc reum

Christi totum Sanguine absolvat a crimine.

Nad furtą klasztorną znajduje się od czasu fundacji obraz przedstawiający oryginalną scenę $\mathrm{z}$ uroczystości przekazania konwentu zakonowi. W oknie furty zachowało się także szkło okienne jeszcze z czasów fundacji. 
Obraz "Zwiastowania" w wielkim ołtarzu jest dziełem artysty malarza Karola Stokalskiego z Rzeszowa z r. 1836. Praca ta została wykonana za rządów gwardiana o. Józefa Krzysikiewicza, który również skatalogował bibliotekę klasztorną. O. Florian Janocha w latach 1906-1908 odnowił całkowicie wnętrze kościoła. Za jego staraniem Wincenty Rogalski wymalował św. Franciszka a prof. Gramatyka obraz św. Feliksa. Polichromię kościoła wykonali: Wawrzyniec Kamecki - polichromię ścian i Bronisław Grzywacz - obrazy na ścianach. W tym okresie sprawiono dwa obrazy św. Józefa. Pierwszy jest dziełem Grzywacza, drugi Karola Wanke art. mal. z Pragi. W r. 1932 nowy obraz św. Józefa wykonał Michał Hołyński. W r. 1928 i póżniej art. mal. Wł. Barwicki pozostawił w kościele i klasztorze wiele swoich prac. Dzieła Barwickiego zawdzięcza klasztor długoletniemu gwardianowi - o. Gerardowi Ryszowi.

Spośród braci w klasztorze pozostawił wdzięczną pamięć br. Walenty Marczak z Jaślisk ( 1870). W dwudziestym roku życia wstąpił on do zakonu. Znany jest jako rzeżbiarz ludowy. W rodzinnym domu pozostawił płaskorzeźbę „Wieczerzę Pańską." Drugą podobną rzeźbę miał zabrać ze sobą do zakonu. W Rozwadowie wykonał "Grób Pański" i dekoracje do wielkiego ołtarza.

Prawie przez 48 lat żyli zakonnicy w Rozwadowie we względnym spokoju, który zakłócony został w r. 1797 przeniesieniem parafii do klasztornego kościoła. Odtąd przez sto lat trwały nieporozumienia między plebanią a klasztorem. W pewnych okresach zakonnicy zamierzali nawet klasztor opuścić. Dopiero wybudowanie kościoła parafialnego przez o. Hieronima Rybę położyło kres stuletnim waśniom. Pomimo tych trudności klasztor odegrał poważną rolę w życiu miasta i okolicy. Spełniał bowiem obowiązki wikarych parafii oraz katechetów szkolnych.

W czasie pierwszej wojny światowej piwnice klasztorne stały się niezastąpionym schronem dla obywateli miasta. O. Honorat Jedliński uratował wtedy klasztor od spalenia. Ponadto w czasie obydwóch wojen światowych klasztor mieścił w swych murach szpital wojskowy.

Klasztor rozwadowski oddał wielkie usługi prowincji krakowskiej. Tutaj bowiem otwarto po pierwszej wojnie światowej seminarium serafickie, które wychowało dla zakonu wielu dzielnych i pracowitych kapłanów. 
2. Historia archiwum

Wielkim skarbem dla klasztoru rozwadowskiego jest pierwsza jego kronika. Zawiera ona dokładne kopie dokumentów odnoszących się do fundacji. Oryginały znajdowały się $w$ archiwum prowincji polskiej. Niemal do r. 1793 możemy dokładnie odtworzyć historię konwentu na podstawie pierwszej kroniki. Lāa póżniejsze są omijane lub bardzo skąpo opisane.

Inwentarz klasztoru z r. 1835 w rubryce „Documenta Conventus" podaje pierwszy wykaz dokumentów. Oto one:

1. Oryginał dokumentu erekcyjnego z dnia 22.V.1741.

2. Wyciąg z protokołu sesji c. k. Sądu Szlacheckiego we Lwowie z dnia 4.V.1789 $\mathrm{w}$ sprawie sumy 17.142 flor. pol. ulokowanych $\mathrm{w}$ dobrach Rzeczyca Długa. Kopia uwierzytelniona.

3. Wyrok c. k. Sądu Szlacheckiego we Lwowie z dnia 25.X.1800 w sprawie sumy pod nr 2, zaintabulowanej 1.IV.1801.

4. Protokół przeniesienia parafii do kościoła klasztornego 16.XII.1798. Kopia uwierzytelniona.

5. Cyrkularz urzędowy z Rzeszowa z dnia 11.X.1799, mocą którego nie proboszcz ale Dominium Rozwadów ma płacić $30 \mathrm{fl}$. rocznie za mieszkanie proboszcza w domu fundatorskim.

6. "Liber compactus variorum documentorum ad Conventum pertinentium".

Oczywiście Liber compactus jest tytułem tak ogólnikowym, że nie można by nic powiedzieć o zawartości tej książki, gdyby nie dalszy ciąg inwentarza z r, 1835. W rubryce "Redditus Monasterii" podaje on w pięciu pozycjach źródła dochodów klasztoru. I tak poz. 1 odpowiada powyższym dokumentom nr 2 i 3, poz. 2 - dokumentowi nr 5. Pozycja 3 obejmuje czynsz od sumy 3.000 zł. pol. włożonej $w$ budowę synagogi przez Stanisława Jackowskiego a póżniej podarowanej przez niego klasztorowi. Pod poz. 4 znajduje się czynsz od kapitału 60 zl. w zamian za srebro zabrane $z$ kościoła klasztornego przez władze austriackie. Najciekawszą wszakże jest ostatnia pozycja nr 5. Na podstawie przywileju nadanego przez króla Augusta III klasztor otrzymał z dóbr królewskich w Nisku 50 korcy zboża i 30 sągów opałowego drzewa. Po rozbiorach przywilej ten uznała austriacka kamera nadworna pod warunkiem, że klasztor co trzeci rok będzie się starał o zatwierdzenie asygnaty. Deputat z Kamery Niskiej został pomniejszony do 45 korcy zboża i 20 sągów drzewa. Należy jeszcze zaznaczyć, że z Funduszu Religij- 
nego konwent otrzymywał rocznie 1000 fl. (Inw. 1831). Inwentarze z r. 1831 i 1835 wykazują pewne odchylenia od podanego spisu, ale główny zrąb spraw majątkowych pozostaje w nich ten sam. Możemy się domyślać, że "Liber compactus" zawierał osobne wiązki aktów, dotyczących wyżej wspomnianych zagadnien, będących podstawą bylu społeczności klasztornej.

Z czasem jednak, gdy deputaty i kapitały wygasły, dokumenty i akta jako zbyteczne wyrzucono do biblioteki klasztornej i nikt się nimi nie zajmował. Nawet $\mathrm{w}$ potrzebie - w późniejszych latach - kancelaria klasztorna obchodziła się bez nich ze szkodą dla dobra sprawy. Podobne były zapewne losy aktów, nadsylanych do klasztoru z kancelarii prowincjalskiej i konsystorskiej. Te ostatnie zostały przynajmniej częściowo skopiowane bądź to w "Protocollum cursoriarum" od r. 18211874, bądź też w kronikach klasztoru.

\section{Opracowanie}

W r. 1957 wydobyto z kurzu zapomnienia z różnych zakamarków bibliotecznych klasztoru rozwadowskiego rozbite wiązki i rozsypane akta. Uporządkowanie całego zespołu przedstawiało znaczne trudności. Pomimo bowiem podobieństwa treści archiwów klasztornych kapucyńskich, nie brak wśród nich odrębności formalnych, które wymagają odmiennych w poszczególnych wypadkach zabiegów porządkowych. Archiwum rozwadowskie pomimo drobnych odchyleń otrzymało w zasadzie układ według wspomnianego na wstępie schematu.

W zespole rozwadowskim najciekawsze jednostki archiwalne stanowią zapisy fundatora, akta mówiące o stosunku parafii do klasztoru, o historii domu fundatorskiego oraz o deputacie drzewa $z$ Kamery Niskiej. Dużą wartość historyczną przedstawiają inwentarze klasztoru oraz "Liber cursoriarum". Zespół aktów, rękopisów i kronik uzupełnia się mniej lub więcej, dając obraz życia klasztoru na przestrzeni dwóch wieków.

\section{Zawartość a r chiw um}

AKR 1. Dokumenty fundacyjne. 1741-1753. $37 \times 25.5 \mathrm{~cm}$, płsk., klb. 10, knlb. 1 .

AKR 2. Encykliki i dekrety papieskie. Rozporządzenia władz zakonnych. 1820-1898:

1. Encykliki papieskie. $1820-1860$. K. 1-12. 
2. Dekret kanonizacyjny św. Laurentego z Brindizi. 1881. K. 13.

3. Rozporządzenia generalskie. 1843-1860. K. 14-21.

4. Rozporządzenia i pisma prowincjalskie. 1806-1918. K. 22 -99.

5. Tabela konwentu na kapitułę. 1837-1912. K. 100-101. $37.2 \times 25 \mathrm{~cm}$, plsk., klb. 100, knlb. 7 .

AKR 3. Rozporządzenia władz duchownych i świeckich. 1781-1887:

1. Listy pasterskie biskupów przemyskich i innych. 1801-1856. K. $102-127$.

2. Rozporządzenia konsystorskie i dziekańskie. 1805-1880. K. $128-204$.

3. Korespondencja klasztoru $\mathrm{z}$ konsystorzem. 1804-1849. K. 205-210.

4. Rozporządzenia władz świeckich. 1781-1887. K. 211-253.

5. Korespondencja klasztoru z władzami świeckimi. 1857-1875. K. 254--255.

$37.2 \times 25.5 \mathrm{~cm}$, płsk., klb. 253, knlb. 6.

AKR 4. Organizacja klasztoru. 1753-1899:

1. Syndyk klasztoru. 1835-1836. K. 1-6.

2. Wykaz zakonników. 1820-1897. K. 7-24.

3. Zapis fundatora $1200 \mathrm{zł}$ na fundacje rozwadowską. 1753-1855. K. 25-67.

4. Sprawa parafii w kościele klasztornym oraz mieszkania proboszcza w klasztorze i płacenia przezeń czynșzu. 17991894. K. 68-100.

5. Pisma i listy do gwardiana i zakonników. 1850-1899. K. $101-116$.

6. Restauracja kościoła i klasztoru. 1812-1878. K. 117-136. $37 \times 25.5 \mathrm{~cm}$, płsk., klb. 136, knlb. 8.

AKR 5. Inwentarze kościoła i klasztoru z lat: 1785, 1824, 1828, 1831, 1835, 1855.

$40 \times 26 \mathrm{~cm}$, płsk., klb. 70, knlb. 2 .

AKR 6. Inwentarz kościoła i klasztoru. 1828.

45 x $29.8 \mathrm{~cm}$, płsk., klb. 43, knlb. 2.

AKR 7. "Visitatio infirmorum”. [1870-1901].

$34.8 \times 21.3 \mathrm{~cm}$, płsk., klb. 39 , knlb. 1 . 
AKR 8. "Księga Braci i Sióstr III-go Zakonu OO. Kapucynów w Rozwadowie nad Sanem". [1900-1931]. $33 \times 20.7 \mathrm{~cm}$, pap., slb. 130, knlb. 2.

AKR 9. „Księga fundatorów i dobrodziejów kościoła parafialnego w Rozwadowie i kronika kościoła w Woli". [O. Hieronima Ryby. 1894-1922].

$32.5 \times 20.5 \mathrm{~cm}$, płsk., klb. 115, knlb. 1 .

AKR 10. "Consignatio librorum P. P. Capucinorum in Bibliotheca Rosvadoviensi reperibilium die 21 Julii Anno Domini 1823 conscripta". $38.3 \times 23.8 \mathrm{~cm}$, płsk., slb. \&0, knl. 1 .

AKR 11. Hipoteka. Dochody-rozchody. 1804-1902. $37.2 \times 25 \mathrm{~cm}$., płsk., klb. 52, knlb. 2 .

AKR 12. "Przychód i wychód. 1816-1841". $34.5 \times 20 \mathrm{~cm}$, płsk., slb. 40+116, knlb. 1 .

AKR 13. "Księga dochodów i rozchodów". [1825-1829]. $33.7 \times 11.5 \mathrm{~cm}$, płsk., slb. $15+5$, knlb. 1 .

AKR 14. "Księga dochodów i rozchodów". [1840-1883. Kronika klasztorna. 1908-1913].

Kronika od k, 10-33.

$36.8 \times 23 \mathrm{~cm}$, plsk., klb. $33+89$, knlb. 1 .

AKR 15. "Księga dochodów i rozchodów". [1853-1884].

$39.2 \times 12.2 \mathrm{~cm}$, płsk., slb. 174, knlb. 2.

AKR 16. "Księga dochodów i rozchodów". [1928-1932].

34 x $22.5 \mathrm{~cm}$, plpł., klb. 134, knlb. 1.

AKR 17. Fundusz religijny. 1795-1937.

37 x $24 \mathrm{~cm}$, płsk., kib. 193, knlb. 1 .

AKR 18. "Liber Missarum". [1826-1840].

$37.2 \times 11.5 \mathrm{~cm}$, płsk., slb. 178, knlb. 1.

AKR 19. "Missae absolutae ex fundo religionis". [1829-1832].

$32.2 \times 10 \mathrm{~cm}$, płsk., slb. 83, knlb. 1 .

AKR 20. "Liber Missarum". [1840-1882].

33.9 × $10,5 \mathrm{~cm}$, płsk., slb. 376, knlb. 1.

AKR 21. "Liber Missarum", [1870-1897]:

$33.9 \times 20.8 \mathrm{~cm}$, płsk., slb. 222 , knlb. 1 .

AKR 22. Obligacje. Pożyczki. Długi. Legaty. Deputaty. Podatki. Kwity. 1801-1890:

1. Obligacje. 1831-1876. K. 1-14.

2. Pożyczki. Długi. 1838-1840. K. 15-24. 
3. Legaty. Testamenty. 1839-1887. K. 25-36.

4. Deputat drzewa i zboża z Kamery Niskiej. 1801-1842. K. 37-99.

5. Podatki. 1833-1836. K. 100-148. $37 \times 24.5 \mathrm{~cm}$, płsk., klb. 147 , knlb. 8.

AKR 23. "Protocollum cursoriarum variarumque ordinationum consi= storialium incipiendo a die 20 Novembris A. 1826 sub guardianatu Patris Procopii Werner Capuccini Rosvadoviensis". [1821-1874].

$40.6 \times 25.5 \mathrm{~cm}$, plsk., slb. 114, knlb. 1 .

AKR 24. "Protocollum gestionis". [1832-1856].

$36.8 \times 22.5 \mathrm{~cm}$, płsk., klb. 18 , knlb. 2 .

AKR 25. "Protocollum gestionis". [1840-1865].

$35.3 \times 20.5 \mathrm{~cm}$, płsk., klb. 18, knlb. 1 .

AKR 26. „Tomus Primus. Chronologia seu Historia Conventus Rosvadoviensis P. P. Capucinorum a fundatione ab anno 1740 usque ad, a. 1862".

33 x $20 \mathrm{~cm}$, plsk., slb. 211, knlb. 3 .

AKR 27. "Tomus II-dus Chronologiae Conventus Rosvadoviensis P. P. Capucinorum ab anno 1862 usque ad (a. 1908)".

$38.8 \times 24.5 \mathrm{~cm}$, płsk., slb. 164 .

AKR 28. "Kronika klasztoru rozwadowskiego od 15 listopada 1917 r." [1917-1934].

$33.5 \times 20.5 \mathrm{~cm}$, płpł., slb. 186, knlb. 5 .

AKR 29. "Kronika Klasztoru OO. Kapucynów w Rozwadowie. Od roku 1935". [1935-1939].

$33.7 \times 20.5 \mathrm{~cm}$, plpł., klb. zapis. 30 .

AKR 30. „Kronika klasztoru w Rozwadowie od dnia 1 września 1939 do 31 grudnia 1941".

$20.3 \times 16.3 \mathrm{~cm}, \mathrm{pl}, \mathrm{k} \mathrm{lb} .146$.

AKR 31. "Kronika klasztorna 1942 do 31.VIII.1943". $19.8 \times 16 \mathrm{~cm}$, płpł., klb. 94.

AKR 32. "Kronika klasztorna od 1 września 1943 do 30 czerwca 1944". $20 \times 15.5 \mathrm{~cm}$, płpł., klb. 93 .

AKR 33. "Kronika klasztoru rozwadowskiego od dnia 1 lipca 1944". [1944-194.7]. $20.8 \times 16.7 \mathrm{~cm}$, płpł., klb. 161. 


\section{ARCHIWUM KLASZTORU W OSTROGU}

\section{Historia klasztoru}

Książę Janusz Sanguszko ordynat ostrogski podarował kapucynom miejsce pod fundację dnia 3.IV.1750 r. Plany budowy klasztoru wykonał Paweł Antoni Fontana. Budowę zakończono w r. 1766, częściowo kosztem Samuela Eubkowskiego starosty taborowskiego, a później staraniem Kanuta Feliksa Malińskiego miecznika wołyńskiego. Aktu konsekracji kościoła pod wezwaniem św. Trójcy dokonał w r. 1778 bp Franciszek Komornicki sufragan łucki. Kapucyni zobowiązali się głosić kazania w kościele parafialnym we wszystkie niedziele i święta. Kościól posiadał 8 drewnianych ołtarzy. Biblioteka klasztorna liczyła 819 dziel z przewagą pozycji łacińskich i polskich. „Kapucyni mieli też swoją aptekę, z której dawali ubogim lekarstwa bezpłatnie; również w latach głodowych żywili stale chlebem i gotowaną strawą ubogich, bez różnicy wyznań. W ogóle po kapucynach pozostały nader chlubne wspomnienia." Klasztor uległ kasacie w r. 1832. Mienie klasztorne przejęło państwo zaborcze. Kościół przekšztałcono w r. 1866 na cerkiew prawosławną.

W r. 1924 w dawnym klasztorze zainstalowano internat seminarium nauczycielskiego. Cerkiew wyświęcono na kaplicę szkolną. W r. 1938 w klasztorze znajdowały się dwie klasy szkoły powszechnej i część internatu. $\mathrm{Z}$ czasem gmach objęło w całości liceum pedagogiczne.

Starania o odzyskanie klasztoru przez Prowincję Krakowską OO. Kdpucynów rozpoczął w r. 1938 komisarz prowincjalny o. Gerard Rysz. Dnia 16.XII.1938 r. o. Donat a Welle generał zakonu zgodził się na przejęcie klasztoru. W styczniu 1939 Kuria Biskupia Eucka udzieliła aprobaty pierwszemu przełożonemu klasztoru o. Gabrielowi Banasiowi a tamtejszy biskup ordynariusz wyrazil swoją radość z powodu objęcia kościoła przez dawnych właścicieli. Uroczysty ingres kapucynów do kościoła klasztornego odbył się 13.VIII.1939 r.

W czasie drugiej wojny światowej zakonnicy tutejsi zapisali się złotymi głoskami w historii miasta. O. Remigiusz Kranc ochronił przed grożącą śmiercią z rąk ukraińskich banderowców przeszło 5000 Polaków z miasta i okolicy, których zamknął w obronnym obozie, utworzonym z miejscowego więzienia karnego i liceum pedagogicznego. Dnia 17.I.1944 r., gdy napadnięte miasto płonęło, nadciągnął z odsieczą o. Gabriel Banaś administrator parafii w Ożeninie, który już wcześniej zorga- 
nizował swoją parafię w celach obrony. Po dwutygodniowych zmaganiach niemal w stylu Sienkiewiczowskiej epopei "Ogniem i Mieczem" $\mathrm{z}$ bandami separatystów ukraińskich, oblężeni złożyli broń w ręce wkraczającej do miasta regularnej Armii Czerwonej. Prawie wszyscy obrońcy wstąpili w szeregi Armii Polskiej utworzonej w ZSRR. O. Remigiusz natomiast ofiarował okryty chwałą sztandar Armii Polskiej. Uroczyste przekazanie sztandaru odbyło się 17.IV.1944 r. w ręce zastępcy dowódcy AP w ZSRR gen. dywizji Karola Świerczewskiego, który po ucałowaniu sztandaru oświadczył: „Ten pierwszy sztandar polski z ziemi okupowanej będzie symbolem zjednoczenia wszystkich Polaków walczących z Niemcem, zarówno pod okupacją jak i w szeregach naszej armii. Sztandar ten staje się jednym z naszych sztandarów i będzie nas prowadził $z$ innymi sztandarami do walki o Polskę."

O. Honorat Jedliński w innych okolicach Ostroga odegrał również rolę obrońcy ludności polskiej. Ukraińcy, mszcząc się, powiesili go za nogi u żyrandola $\mathrm{w}$ kościele.

Gdy przeszła zawierucha wojenna, ojcowie wraz z polską ludnością opuścili w r. 1945 miasto Ostróg i okgolicę.

$\mathrm{Z}$ archiwum klasztornego pozostało tylko kilka listów.

\section{Zawartość archiwum}

AKOS 1. Listy do przełożonego konwentu z r. 1939.

VII. ARCIHIWUM KLASZTORU W KUTKORZU

1. Historia klasztoru

Kutkorz leży na południowy wschód od Lwowa. W dawnych czasach słynął z rządowej prochowni, wielkich młynów oraz z papierni.

Osada ta należała do dóbr rodziny Łączyńskich. Hr. Jerzy Antoni Nałęcz Łączyński kasztelan lwowski i chorąży żydaczowski wybudowal okazały pałac, ratusz i kilkadziesiąt domów dla służby. Wzniósł również drewniany kościółek pod wezwaniem św. Jerzego, przy którym po+ starał się o erygowanie parafii w r. 1725. W tym roku sprowadził do kościółka z Lublina obraz M. B. Snieżnej. Ze względu na nią nadał miasteczku nazwę Marianów.

Obowiązki duszpasterskie przy kościele spełniali różni zakonnicy m. i. dominikanie i trynitarze. Zakonnicy ci opuszczali placówkę, ponie- 
waż Éączyński nie spelnil przyrzeczenia i nie wybudował murowanego kościoła i klasztoru.

W r. 1753, za poparciem arcybpa M. P. Wyżyckiego, Eączyński sprowadził kapucynów do obsługi kościoła. Ze strony zakonu sprawy fundacyjne załatwiał o. Piotr Raudnicensis wizytator i kustosz prowincji. Dnia 1 stycznia 1753 objął w zarząd kościół, parafię, plac wyznaczony pod fundację i ơród. Dnia 4 marca o. Nepomucen z Krakowa objąl administracje parafii i kierownictwo budowy klasztoru. Kapituła prowincji zebrana w Krakowie 11 września 1753 r. zatwierdziła przyjęcie placówki w charaḱterze stacji misyjnej dla prac na Rusi. Łączyński, będąc $w$ podeszłym już wieku, przeznaczył $w$ testamencie ná fundację 40.000 złp. i zapewnił zakonnikom utrzymanie z dóbr kutkorskich. Otrzymywać mieli rocznie: 40 półmiarek jęczmienia, 200 łupek soli, wolny wyrąb drzewa, wolne mlewo i łąkę Dukowską.

Budowę klasztoru rozpoczęto szybko ale doprowadzono ją tylko do parteru. Albowiem dnia 1 lipca 1754 zmarł fundator i prace wstrzymano ze względu na niepewne czasy, wojny, jak też złą wolę sukcesorów, którzy nie zamierzali wprowadzić w życie woli testatora. Fundusz przeznaczony na fundację spadkobiercy roztrwonili. Ze zgromadzonych materiałów zbudowali karczmę a zakonnikom odmówili prawa do legatów fundatora. Kapucyni na drodze sądowej szukali sprawiedliwości i uratowali zaledwie połowę dotacji. Gubernium za Józefa II zagroziło, że jeśli Łączyńscy do r. 1800 nie wzniosą kościoła i klasztoru, wtedy już nie wolno im będzie budować. Ażeby więc uratować honor, postawili mały kościółek i klasztorek za rządów komisarza prowincjalnego o. Aleksandra.

W starym drewnianym klasztorku kapucyni mieszkali 50 lat, to jest do r. 1803, w którym zakończono budowę nowego konwentu. Kościół poświęcił dziekan z Buska ks. Ignacy Treter dnia 4 października 1803 r. Wtedy też przeniesiono łaskami słynący obraz M. B. Śnieżnej do wielkiego ołtarza.

. Cały kościółek i klasztor odnowił w r. 1850 o. Józef Krzysik. Zaprowadził Bractwo Różańcowe, nauczył lud śpiewać różaniec, nieszpory i odprawiać Drogę Krzyżową. Dzięki swej niestrudzonej działalności duszpasterskiej ożywił i utrwalił ducha religijnego w całej rozległej parafii.

Kościół pod wezwaniem N. M. P. Śnieżnej ma tylko jedną nawę i zbudowany jest w stylu neoromańskim. Sufit $z$ desek bez murowanego sklepienia. W bocznym ołtarzu od strony epistoły znajduje się 
ołtarz z obrazem św. Franciszka; w ołtarzu od strony ewangelii jest obraz Pana Jezusa Miłosiernego „Ecce Homo." Obydwa obrazy pędzla Marcina Jabłońskiego z r. 1852.

Obraz M. B. Snieżnej, malowany na płótnie pochodzi z lubelskiego klasztoru OO. Jezuitów. Tam wisiał na ścianie przy furcie klasztornej i doznawał wielkiej czci. W dowód wdzięczności wierni zawieszali przed obrazem liczne wota. Obraz ten miał przysłać do Lublina św. Franciszek Borgiasz w r. 1560 jako wierną kopię cudownego obrazu z rzymskiego kościoła S. Mariae Maioris ad Nives. Na usilne prośby fundatora jezuita o. Tymieniecki podarował go w r. 1725 do Kutkorza. Z czasem obraz otrzymał srebrne korony i sukienkę. Matka Boska Snieżna zasłynęła łaskami i stała się opiekunką i patronką całej parafii i okolicy.

\section{Historia archiwum}

Kutkorz należy do konwentów, które nie uległy kasacie. Dlatego archiwum klasztoru oraz archiwa prowincji i zniesionych klasztorów powinny się tutaj zachować w całości. Tak jednak nie było. W r. 1852 prowincjał o. Abel prosił gwardiana kutkorskiego o. Józefa Krzysika o pewne informacje dotyczące prowincji. Otrzymał wtedy odpowiedż, że, jakkolwiek dobrze przeszukał akta konwentu, nie znalazł ani śladu żądanych dokumentów. Więcej nic nie da się powiedzieć o archiwum konwentu, które o. Wojciech Strzemecki, ostatni przełożony pozostawil na miejscu po opuszczeniu klasztoru w r. 1944.

3. Zawartość archiwum

AKUT 1. Akta konwentu. 1787-1873.

$42.5 \times 25.5 \mathrm{~cm}$, płsk., klb. 40, knlb. 3 .

AKUT 2. "Liber normalium memorabilium Conventus Kutkuriensis". [1827-1830]. $39.4 \times 24.5 \mathrm{~cm}$, płsk., klb. 43, knlb. 1 .

AKUT 3. "Annales Conventus Kutkuriensis. Ab exordio et introductione anno 1753 sunt insertae". [T. I. 1753-1910]. $40 \times 23.5 \mathrm{~cm}$, płsk., slb. 106, knlb. 8 .

AKUT 4. "Historia klasztoru OO. Kapucynów w Kutkorzu". [T. II. 1901-1939]. $34.2 \times 20.3 \mathrm{~cm}$, płsk., slb. $248+13$ kart, pozostałe strony niezapisane. 
VIII. ARCHIWUM KLASZTORU W KROSNIE

\section{Historia klasztoru}

Klasztor w Krośnie nie miał jednego fundatora. Na jego budowę złożyły się dary wielmożów, szlachty, księży, mieszczan i ludu. Z ramienia zakonu budowe prowadził o. Innocenty Barth, z pochodzenia Czech, najbardziej zasłużony w dziejach klasztoru i właściwy jego założyciel.

Pierwszy ofiarodawca Aleksander Jaworski b. rejent sanocki wraz $\mathrm{z}$ definitorem prowincjalnym o. Fidelisem wybrał Krosno na miejsce fundacji, na którą złożył w ręce biskupa przemyskiego Wacława Hieronima Sierakowskiego 170000 złp. Z tej sumy tylko pewną część zuży to na wymienioną fundację. Uszczuplony fundusz pomnożyły z czasem legaty różnych osób.

Wśród nich na pierwszym miejscu należy postawić hr. Branickiego. Jan Klemens Branicki, wojewoda krakowski, hetman wielki koronny, dzierżawca miasta Krosna, uproszony o wydzierżawienie placu pod budowę, polecił Adamowi Lewickiemu podstarościemu grodzkiemu przemyskiemu, aby zakupił z osobistej jego kasy place pod fundację. Zarządzenie to wydał Branicki w Tyczynie 1 października $1753 \mathrm{r}$. w tym celiu, :,aby chwała Pana Boga przez ten przykładny zakon rozszerzała się".

Na prośbę kảpucynów bp Wacław Hieronim Sierakowski ogłosit 27 grudnia 1753 r. w katedrze przemyskiej "litterae cridae", które odczytano również 30 grudnia tegoż roku w kościele prepozyturalnym w Krośnie. Po przełamaniu początkowych trudności, biskup nakazał w dniu 29 maja $1754 \mathrm{r}$. przyjęcie ofiarowanego gruntu i wzniesienie na nim krzyża stosownie do prawnych przepisów Kościoła.

W międzyczasie Lewicki zakrzątnął się około zleconej sprawy. Dnia 13 września 1754 r. zakupił za murami miasta plac od obywatela Baltazara Pańkowskiego za 1000 złp. Branicki zwrócił się równocześnie do króla z prośbą o zezwolenie na zakup placów pod fundację. August III pismem z dnia 16 grudnia powiadomił radę miasta o udzieleniu swego zezwolenia. Pertraktacje o kupno drugiego placu trwały dość długo. Ostatecznie rozstrzygnęły się 22 kwietnia 1757 r., kiedy to mieszczanin krośnieński Tomasz Krzyżanowski w imieniu swoim i sukcesorów sprzedał plac z domem obok ogrodu Pańkowskiego za sumę 1000 złp. Plac ten przylegał do kościoła św. Jakuba ofiarowanego przez biskupa zakonowi. Tegoż dnia nastąpiło wprowadzenie kapucynów do domu i ogro- 
dów a 26 kwietnia urzędowo przekazano zakupione posesje na własność zakonu.

Budowę kościoła rozpoczęto $15 \mathrm{kwietnia} 1771 \mathrm{r}$. Zakładanie fundamentów trwało aż do 1773 r. Do r. 1781 postawiono same ściany bez sklepienia. W okresie „józefinizmu“ groźba kasaty wstrzymała wszelkie prace. Dopiero od 1807 r. o. Innocenty poprowadził dalsze prace aż do r. 1809. Pięknie wykończony kościół został poświęcony przez biskupa przemyskiego Antoniego Gołaszewskiego dnia 14 września $1811 \mathrm{r}$.

Kościół został wzniesiony $w$ stylu barokowym pod wezwaniem Podwyższenia Krzyża św. Polichromię wnętrz wykonali: Smuglewicz i Andrzej Kucharski. Polichromia była odnawiana i częściowo zmieniana. w latach 1869 przez Sroczyńskiego, 1879 przez Tabińskiego i w 1914 oraz 1929 przez art. mal. Juliana Krupskiego prof. Szkoły Przemysłowej we Lwowie. Dawną polichromię odrestaurował w r. 1956 art. mal. Wiktor Ingling.

Obrazy do ołtarzy wykonali: A. Kucharski i Paweł Bogdański. Obrazy czterech ewangelistów namalował w r. 1858 Michał Rogowski.

O. Innocenty zdołał wykończyć tylko część klasztoru. Resztę dokończył w r. 1853 o. Józef Krzysik, jeden z najwybitniejszych kapucynów prowincji galicyjskiej.

W klasztorze przebywali zakonnicy bardzo zasłużeni dla zakonu i Kościoła. Oprócz o. Innocentego i o. Józefa, organizatora IJI Zakonu i licznych bractw kościelnych, niezmordowanego spowiednika i malarza-amatora, należy wymienić o. Konstantego Jaronia, jednego z najlepszych misjonarzy ludowych. Tu przebywał także br. Rajmund wybitny artysta-dekorator.

W okresie dwóch wieków istnienia klasztor prowadził pracę duszpasterską $\mathrm{w}$ szerokim zakresie, propagował $\mathrm{z}$ powodzeniem III Zakon oraz zakładał liczne bractwa kościelne. Po rabacji galicyjskiej dostarczył kapłanów, którzy prowadzili misje wśród wzburzonego ludu a przed wogną światową stąd wyruszyła grupa misjonarzy do Diecezji Krakowskiej.

Dziś mury klasztoru krośnieńskiego pełnią rolę domu emerytów dla starszych zakonników. Atoli praca duszpasterska kwitnie tu jak dawniej.

\section{Historia archiwum}

Klasztor w Krośnie gromadził akta od początku swego istnienia. Historycy konwentu piszący kronikę domową stale powołują się na akta, które znajdują się w archiwum lub też w archiwum zostały złożone. 
W pierwszych latach istnienia klasztoru kronikarze zaznaczają, że oryginały różnych dokumentów znajdują się w warszawskim archiwum prowincji, klasztor zaś posiada ich odpisy lub też nie ma nawet kopii.

Inwentarza dawnego nie odnaleziono, bo nigdy nie istniał. Wykaz dokumentów i aktów spotyka się po raz pierwszy w "Synopsis exhibitorum" p. t. "Consignatio actorum Conventus Krosnensis P. P. Capucinorum, quae tempore visitationis canonicae Admodum Reverendi Patris Clementis a Końska Wola Borkowski Vicarii Provincialis die 4 Aprilis 1831 confecta erat, in praesentia Admodum Reverendi Patris Procopii Werner guardiani Krosnensis“. Pod tytułem „Imprimis sequuntur acta fundationalia Conventus Crosnensis" mieści się wykaz i streszczenie czterech zasadniczych dokumentów dotyczących fundacji. W dalszym ciągu wykazane są akta z lat 1808-1831 w ilości 23 sztuk. Pod wykazem znajduje się objaśnienie, że spis został wykonany i sprawdzony w czasie wizytacji przez wikarego prowincji oraz przez ks. dziek. Józefa Olszewskiego proboszcza z Łączek w czasie wizytacji dziekańskiej.

Spis z r. 1831 ma wielkie znaczenie dla dziejów archiwum klasztornego. Wykazuje bowiem, że już w r. 1831 poza dokumentami fundacyjnymi i małą ilością akt nie było tu nic więcej. Ocalałe natomiast akta, na skutek zarządzenia wizytacyjnego, ujęto w "Synopsis exhibitorum", które rejestrowało wszystkie pisma przechodzące przez kancelarię klasztorną. Wiele z tych pism zaginęło, ale Synopsis zachowało przynajmniej ich streszczenia.

W czasie wizytacji tak prowincjałów jak i dziekanów Synopsis było przeglądane i podpisywane. Fakt ten zmuszał gwardianów do mniej lub więcej rzetelnego prowadzenia podstawowej i bardzo ważnej księgi w ówczesnej kancelarii klasztornej.

Duże znaczenie dla historii konwentu mają także zachowane do dziś dwie księgi „Prothocollum ordinationum", w których znajdujemy kopie zarządzeń władz zakonnych, kościelnych i trzy tomy kronik klasztornych, wzorowo prowadzonych i dokładnie odzwierciedlających życie konwentu od fundacji do r. 1930.

\section{Opracowanie}

Dokumenty i akta znajdowały się $\mathrm{w}$ bibliotece klasztornej w Krośnie. Należało je tylko uporządkować i wraz z ininymi rękopisami klasztornymi uszeregować według z góry ułożonego planu.

W klasztorze pozostają jeszcze dokumenty odpustowe oraz mortuologium. 
4. Zaw artość archiwum

AKKR 1. Dokumenty fundacyjne. 1753-1757.

$36.2 \times 24 \mathrm{~cm}$, płsk., klb. 15, knlb. 1 .

AKKR 2. Rozporządzenia władz duchownych i świeckich. Korespondencja klasztoru. 1782-1884:

1. Rozporządzenia generalskie. 1850-1860. K. 1-11.

2. Rozporządzenia prowincjalskie. 1835-1873. K. 12-61.

3. Zawiadomienia o kapitule. 1843-1876. K. 62-69.

4. Statystyczne tabele konwentu przedstawiane kapitule. 1828-1912. K. 70-73.

5. Familie konwentu ułożone na kapitule. 1843-1882. K. $74-79$.

6. Encykliki pokapitulne. 1849-1864. K. 80-83.

7. Zaproszenia na sesje definitorską. 1856-1871. K. 84-88.

8. Rozporządzenia konsystorskie i dziekańskie. 1782-1884. K. $89-119$.

9. Pisma magistratu i innych władz świeckich do klasztoru. 1835-1899. K. 120-175.

10. Pisma klasztoru do magistratu i innych władz świeckich. 1810-1876. K. 176-197. $36.2 \times 24.7 \mathrm{~cm}$, płsk., klb. 197, knlb. 14 .

AKKR 3. Organizacja klasztoru. Inwentarze. 1791-1918:

1. Wybór gwardiana. 1791. K. 1-2.

2. Tabele stanu personalnego sporządzane z okazji wizytacji biskupa. 1828. K. 3-8.

3. Spis zakonników do schematyzmu. 1849. K. 9.

4. Wykaz zakonników dla Namiestnictwa. 1869-1874. K. $10-13$.

5. Obediencje kwestarskie. 1865-1868. K. 14-15.

6. Akta księży diecezjalnych odbywających w klasztorze pokutę. 1806-1864. K. 16-92.

7. Zezwolenie na założenie Bractwa N. S. Jezusowego. 1860. K. 9.

8. Korespondencja gwardianów. 1832-1875. K. 94-107.

9. Reparacje kościoła i klasztoru. 1832-1918. K. 108-125.

10. Rachunki za organy. 1913-1916. K. 126-136.

11. Opis klasztoru. 1828. K. 136-140.

12. Inwentarze kościoła i klasztoru. (Dwa z r. 1821 i 1 z r. 1829). K. 140-155. 
13. Inwentarze kościoła, klasztoru i biblioteki. (Oryginał z r. 1829 i odpis z r. 1887; dwa akta Namiestnictwa w tej sprawie). K. 156-206.

14. Budowa szkoły żeńskiej w Iwoniczu. 1883. K. 207-210. $36.4 \times 25 \mathrm{~cm}$, płsk., klb. 169, knlb. 16.

AKKR 4. "Księga bracka". [1858-1900].

35, , $21.3 \mathrm{~cm}$, płsk., knlb. 300 .

AKKR 5. "Księga bracka“. [1891-1929].

33.5 x $21 \mathrm{~cm}$, płsk., klb. 183, knlb. 1 .

AKKR 6. Sprawy majątkowe. 1788-1910:

1. Hipoteka. 1862-1878. K. 1-12.

2. Dochody i rozchody. 1788-1887. K. 13-66.

3. Podatki. 1822-1910. K. 67-169. 36.4 × $24.5 \mathrm{~cm}$, płsk., klb. 169 , knlb. 6.

AKKR 7. Fundusz religijny. 1826-1900.

36.3 x $23.8 \mathrm{~cm}$, płsk., klb. 188, knlb. 2.

AKKR 8. Legaty. Testamenty. 1817-1912.

$36.3 \times 24.8 \mathrm{~cm}$, płsk., klb. 286.

AKKR 9. „Księga legatów“. [1888-1930]. $34.9 \times 20.5 \mathrm{~cm}$, płsk., klb. 25, knlb. 1 .

AKKR 10. Procesy. Kontrakty. Długi. Polisy. Kwity. 1732-1918:

1. Procesy. 1752-1888. K. 1-48.

2. Kontrakty. Kupno-sprzedaż. 1855-1888. K. 49-55.

3. Dzierżawy. 1897. K. 56-57.

4. Wierzytelności. Długi. 1830-1878. K. 58-63.

5. Polisy ubezpieczeniowe. 1895-1918. K. 64-95.

6. Kwity. 1821-1913. K. 96-112. 36.3 × $24.5 \mathrm{~cm}$, płsk., klb. 112 , knlb. 8.

AKKR 11. „Prothocollum ordinationum suae Maiestatis, Excelsi Gubernii, C. Rii Circularis Officii, Reverendissimi Consistorii R. L. Premisliensis et Decanatus Officii et Superiorum Ordinis nostri“. [1828-1871].

38 × $23.2 \mathrm{~cm}$, płsk., klb. 57 .

AKKR 12. "Protocollum Ordinationum". [1872-1935].

$39 \times 24 \mathrm{~cm}$, płsk., klb. 91.

AKKR 13. „Księga rozporządzeń od 1 października 1935".

$34.5 \times 20 \mathrm{~cm}$, płpł., klb. 49 , pozost. nlb.

AKKR 14. „Synopsis exhibitorum". [1753-1880].

$38 \times 23.5 \mathrm{~cm}$, płsk., klb., 45, knlb. 1 . 
AKKR 15. Chronologiae Conventus liber primus. 1753-1828. 34 x $22.4 \mathrm{~cm}$, płsk., klb. 58 .

AKKR 16. Chronologiae Conventus liber secundus. 1837-1903. 33.2 × $20.2 \mathrm{~cm}$, płsk., slb. 156.

AKKR 17. Chronologiae Conventus liber tertius. $1908-1930$. $39.5 \times 24.5 \mathrm{~cm}$, pł., slb. 199 .

AKKR 18. Chronolagiae Conventus Crosnensis. Liber quartus. 1930. $33 \times 20 \mathrm{~cm}$, pł., klb. zapis. 134 .

\section{ARCHIWUM KLASZTORU W ZAMARSTYNOWIE}

\section{Historia klasztoru}

W r. 1903 metropolita lwowski arcybp Józef Bilczewski postanowił wydzielić osiedle Zamarstynów z parafii św. Marcina we Lwowie i utworzyć tamże osobną ekspozyturę, którą zaproponował Zakonowi Kapucynów. Prowincjał o. Ignacy Kolbusz na sesji nadzwyczajnej definitorów w Sędziszowie odbytej dnia 10.II.1904 r. przedstawił sprawę przyjęcia nowej placówki. Uczestnicy sesji jednogłośnie uchwalili przyjęcie placówki wraz z duszpasterstwem parafialnym. Generał zakonu o. Bernard ab Andermatt dnia 7.IV.1904 r. wyraził zgodę na przyjęcie placówki, ale pod warunkiem nadesłania pisemnej zgody arcybiskupa. Ponieważ tok załatwiania sprawy przebiegał pomyślnie, o. Rudolf gwardian kutkorski poświęcił w dniu 3 czerwca kamień węgielny pod budowę tymczasowego domu mieszkalnego a o. Bronisław Stepek - 12 czerwca kamień węgielny pod budowę tymczasowej-kaplicy. Dnia 13 lipca wprowadzono uroczyście zakonników do kaplicy a ks. Świderski kanonik kapituły i wicedziekan miejski poświęcił kaplicę. Pierwszym przełożonym został o. Bronisław Stepek. Nowa ekspozytura obejmowała Hołosko Małe, Fołosko Wielkie oraz część gminy Zamarstynów na lewym brzegu Pełtwi. W dniu 11.II.1905 r. Kongregacja Biskupów i Zakonników udzieliła generałowi zakonu potrzebnych władz do kanonicznej erekcji konwentu w Zamarstynowie. Generał 17.II.1905 r. ogłosił prawną erekcję klasztoru. Arcybp Bilczewski dnia 5.VII.1912 r. stworzył w Zamarstynowie samodzielną ekspozyturę, którą Namiestnictwo zatwierdziło 1.XI.1912 r. Erekcja parafii nastąpiła 4.X.1921 r. W r. 1926 parafia została prawnie złączona z klasztorem.

$\mathrm{Z}$ braku funduszów i z powodu wybuchu pierwszej wojny światowej o budowie murowanego kościoła nikt nie myślał. Dopiero na życzenie komisarza prowincjonalnego o. Czesława Szubera nowy gwardian 
o. Aleksander Chmura rozpoczął z wiosną 1925 r. wstępne prace do budowy. Projekt kościoła i klasztoru wykonał Jan Sas Zubrzycki prof. Politechniki Lwowskiej. Dnia 4.IV.1925 r. o. Aleksander poświęcił krzyż brzozowy w iniejscu przyszłego wielkiego ołtarza. Na wniosek o. Aleksandra Zubrzycki sporządził plany większego kościoła i sam objął kierownictwo budowy kościoła i klasztoru pod wezwaniem św. Franciszka Serafickiego. Budowę właściwego klasztoru rozpoczęto dopiero w r. 1927. W r. 1928 o. Czesław. wyjechał do USA, gdzie przez 19 miesięcy glosił rekolekcje. Na nową fundację nadesłał 15000 dol. W sumę powyższą należy wliczyć również missalia. Po pokonaniu licznych trudności, o. Aleksander doprowadził budowę do końca. W niedzielę 5.X.1930 r. arcybp Bilczewski dokonał aklu konsekracji nowego kościoła. Dzień ten stał się wielkim świętem dla całego Lwowa i zgromadził tłumy wiernych oraz przedstawicieli władz duchownych i świeckich. Nad Zamarstynowem dominował wspaniały kościół trzynawowy w stylu neogotyckim.

Obraz św. Franciszka patrona kościoła wykonał do wielkiego ołtarza bezinteresownie artysta-malarz o. Efrem z Kcyni, kapucyn.

Fo wyposażeniu wnętrza kuścioła niezmordowany o. Aleksander przystąpil do budowy domu parafialnego, który stał się później ośrodkiem działalności organizacji katolickich. Podniósł się wybitnie poziom moralny najbardziej opuszczonej i zaniedbanej dzielnicy Lwowa. „Bezprocentowa kasa pożyczkowa“ udzielała pożyczek parafianom. "Biblioteka parafialna" służyła wiernym doborowym zespołem książek. Teatr amatorski z desek. scenicznych szerzył kulturę słowa i myśli. Od r. 1940 do 1941 konwent stał otworem dla "Bursy szkoły ogrodniczej" a od r. 1941 do 1944 "Kuchnia ludowa" służyła najbardziej potrzebującym.

Zakon cieszył się tu wielkim wzięciem a oo. Aleksander, Kosma, Czesław i Anioł zyskali powszechny szacunek.

Działalność kapucynów w Zamarstynowie najlepiej charakteryzuje wypowiedź arcybpa Bilczewskiego: „Rzetelna praca tychże ojców nad urobieniem dusz na tej nowej niwie Pańskiej okazała się wydajna i błogosławione przyniosła owoce".

$\mathrm{Z}$ archiwum kapucyńskiego w Zamarstynowie ocalały tylko szczątki.

\section{Z a a r tość archiw u m}

AKZ 1. "Książka kwestarska na budowę kościoła OO. Kapucynów w Zamarstynowie". [1930].

$16.8 \times 10.2 \mathrm{~cm}$, pł., slb. 482 , zapis. 318 . 
AKZ 2. "Kosztorys na urządzenie światła elektrycznego w kościele OO. Kapucynów w Zamarstynowie". [1930].

$32.5 \times 23.5 \mathrm{~cm}$, pap., slb. 7 .

AKZ 3. "Liber confraternitatis SS. Rosarii in Zamarstynów". [19061939].

$34 \times 21 \mathrm{~cm}$, płsk., klb. zapis. 17 .

AKZ 4." „Księga dochodów i rozchodów". [1927-1936].

$31 \times 15.5 \mathrm{~cm}$, płpł., klb. 187.

AKZ 5. 1. "Spis aktów klasztornych". [1904-1924]. K. 1.

2. "Wykaz mszy św. fundacyjnych i legatów". [1904-1945]. K. $23-35$.

3. "Spis papierów wartościowych klasztoru OO. Kapucynów w Zamarstynowie". K. 51-56.

4. "Dziennik podawczy”. [1913-1925]. K. 2-5.

$33.2 \times 20.8 \mathrm{~cm}$, pł., klb. 91,5 .

AKZ 6. „Księga rozporządzen'”. [1910-1942].

$24.7 \times 20 \mathrm{~cm}, \mathrm{p}$., klb. zapis. 119.

AKZ 7. "Kronika klasztoru OO. Kapucynów. Lwów na Zamarstynowie. Od roku pańskiego 1904. 1904-1939".

$40 \times 24.5 \mathrm{~cm}, \mathrm{płsk}$, slb. zapis. 252 .

\section{DE INVENTARIO ARCHIVI PROVINCIAE CRACOVIENSIS ORDINIS FRATRUM MINORUM CAPUCCINORUM}

S u m m a rium

Patres Capuccini ex Italia in Poloniam an. 1681 profecti sunt. Polanorum monasteriorum Italiae provinciae et ab an. 1.738 Bohemorum patrocinium tenuerunt. Internis mutationibus religionis factis pervenit, ut ex conventibus nostris an. 1745 erigeretur provincia Polona, quae an, 1761 a provincia Bohemica sese iuri suo prorsus emancipavit. Quo tempore Polonae provinciae 20 conventus et 220 religiosi erant. Partitis Poloniae terris tres provinciae ortae sunt: provincia Galiciae (1781-1921) quae, cum Polonia in libertatem vindicata esset, dicta est Cracoviensis, provincia Russiae seu Roxolana (1795-1888) et provincia Polona (1681-1921), quae an. 1921 renuntiata est Varsaviensis.

Archivum Provinciae Cracoviensis Ordinis PP. Capuccinorum in unım ordinatum est (1956-1959) Cracoviae, quod inclusit etiam monasteriorum archiva. Copiae archi- 
valium divisae sunt per singula collectanea, et servatis certis normis, ad ordinem rei sunt digesta. Intra limites uniuscuiusque partitionis data est dispositio servato temporum ordine.

Documenta, acta, libri partim servata sunt e turbatione bellorum, sed saepius exstant laesa et gravius corrupta. Quo factum est, ut diligenti curae et tutelae subicerentur et in 129 codices compingerentur. Horum archivaliun copiae in longitudinem 25 metra aequant.

Prina sua parte Archivum Provinciae exhibet particulatim servata volumina regesta munerum provincialium tempore provinciae Galiciensis, Cracoviensis functorum et relicta archivalium provinc:ae Polonae et Roxolanae. Apparatui Archivi Provinciae alleguntur archiva institutorum religiosorum dicioni imprimis viri provincialis subiectorum (uti novitiatus et sacrorum seminaria) atque scripta penes vita functos religiosos inventa. Hic notandum est litterarum heredium $f$, $r$, patris Venceslai Nowakowski ( $\dagger$ 1903), historici et peculiaris Mariologi, qui pretiosum thesaurum imaginum divae Matris praeclarissimae beneficis comparavit adhuc integris Poloniae finibus contentarum. Manuscripta patris Zenonis Gorlicki $(\uparrow 1936)$ continent materiam ad res gestas Ordinis in Polonia illustrandas. Quae quidem materies sunt analecta deletorum librorum Bibliothecae Maximi Lycei Varsaviensis. Ad Legionum Polonarum histoiliam cognoseendam quasi nova lux fieri potest heredium patris Cosmae Lenczowski († 1959), qui primus dictarum legionum curio militaris fuit. Exspectationem etiam movent collectiones patris Angeli Madejewski († 1951) et p. Constantini Jaroń $(\dagger$ 1952), celebriorum oratorum sacrorum. Satis exsecutum est verbis, quantas salebras in cura an masum gerenda Ordo in recuperatis Poloniae terris (1945) praestiterit.

Altera pars in Archivo Provinciae complectitur collectanea archivalium 10 coenobiorum ad provinciam Cracoviensem pertinentium. Quorum ditissimum est archivum monasterii Cracoviensis (1695), quod demum an. 1865 iure provinciae Galiciensi allectum est. In historia Poloniae ille conventus graves habebat partes. Ex hoc conventu exierunt curiones militares, qui aderant foederatis viris Barsiensibus, viris Insurrectionis Kosciusciensis, motus bellici Ianuarii, Legionum Polonarum, alterius belli mundani, patriae rebellionis Varsaviensis. Ad moenia eiusdem conventus refertur quzedam pia ac legenda fama de regum insignibus hic abditis. Ibique nulti viri religiosi in odore sanctitatis vita sunt functi, sicuti $p$. Venceslaus Nowakowski, p. Leander Lendzian, p. Marianus Najdecki, fr. Stephanus Rembiszewski. - Archivi monasterii Leopolisnsis (1708-1785) exiles sunt reliquiae. Omnia eiusdem acta coetus ab abolitione dictus asportaverat. - Dimidium archivi conventus Sendissoviensis (1738), ubi sanctimonia notus vixit p. Stanislaus Krzysik ( $\uparrow$ 1861), deletum est. - Collectanea archivalium monasteriorum Olesci (1739-1785, 1788-1944) et Rosvadoviae (1740) paene sarta tectaque sunt. Hoc in monasterio degebat p. Hieronymus Ryba $(\uparrow 1927)$, qui erat fundator templorum paroeciae Rosvadoviae et Recyciae. - Archiva monasteriorum Ostrogiae (1750-1832, 1939-1945) et Cutcorii (1753-1944) paene evanuerunt. - Acta conventus Crosnae (1753) partim salvata sunt. - Archivorum monasteriorum Leopoli-Zamarstynoviae (1904-1946) et Drohobyciae (1934-1946) exstant taritum fragmenta. - Collectanea archivalium conventus Mariampolii (1742-1783) et in residentia Blisnensi $(1760-1788)$ ab Austriaco coetu abolitionis publice sunt proscripta. 